Nevada

Environmental

Restoration

Project

\title{
Streamlined Approach for
}

Environmental Restoration (SAFER)

Plan for Corrective Action Unit 118:

Area 27 Super Kukla Facility

Nevada Test Site, Nevada

Controlled Copy No.:

Revision No.: 1

September 2006

Approved for public release; further dissemination unlimited.

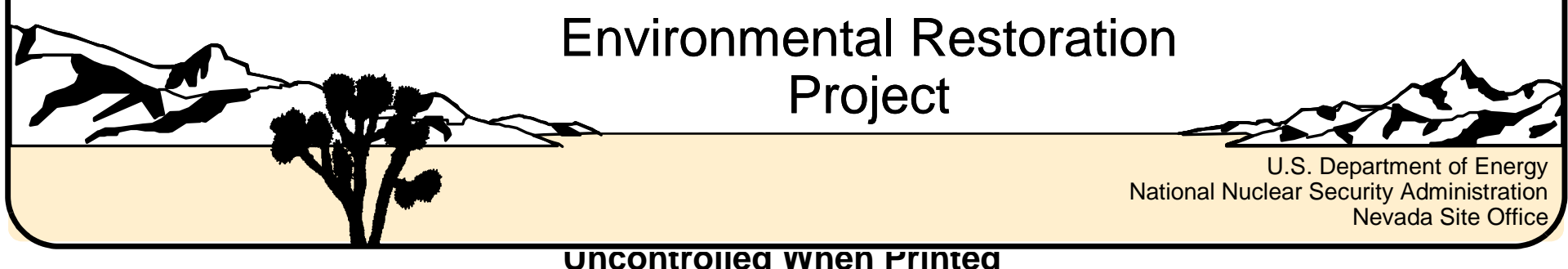


Available for public sale, in paper, from:

U.S. Department of Commerce

National Technical Information Service

5285 Port Royal Road

Springfield, VA 22161

Phone: 800.553 .6847

Fax: 703.605.6900

Email: orders@ntis.gov

Online ordering: http://www.ntis.gov/ordering.htm

Available electronically at http://www.osti.gov/bridge

Available for a processing fee to U.S. Department of Energy and its contractors, in paper, from:

\section{U.S. Department of Energy}

Office of Scientific and Technical Information

P.O. Box 62

Oak Ridge, TN 37831-0062

Phone: 865.576.8401

Fax: 865.576.5728

Email: reports@adonis.osti.gov

Reference herein to any specific commercial product, process, or service by trade name, trademark, manufacturer, or otherwise, does not necessarily constitute or imply its endorsement, recommendation, or favoring by the United States Government or any agency thereof or its contractors or subcontractors. 


\title{
STREAMLINED APPROACH FOR ENVIRONMENTAL RESTORATION (SAFER) PLAN FOR CORRECTIVE ACTION UNIT 118: AREA 27 SUPER KUKLA FACILITY NEVADA TEST SITE, NEVADA
}

\author{
U.S. Department of Energy \\ National Nuclear Security Administration \\ Nevada Site Office \\ Las Vegas, Nevada
}

Controlled Copy No.:

Revision No.: 1

September 2006

Approved for public release; further dissemination unlimited. 
STREAMLINED APPROACH FOR ENVIRONMENTAL RESTORATION (SAFER) PLAN FOR CORRECTIVE ACTION UNIT 118: AREA 27 SUPER KUKLA FACILITY NEVADA TEST SITE, NEVADA

Kevin Cabble

Federal Sub-Project Director

Industrial Sites Sub-Project

Approved by:

APPROVED SIGNATURE

Date:

Janet Appenzeller-Wing

Federal Project Director

Environmental Restoration Project 


\section{Table of Contents}

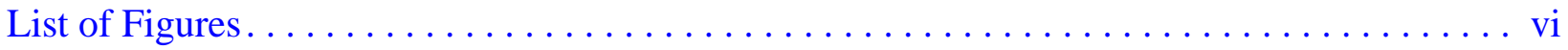

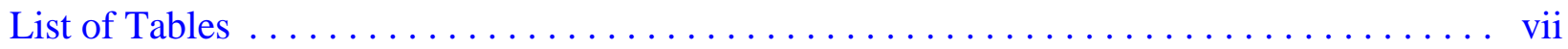

List of Acronyms and Abbreviations $\ldots \ldots \ldots \ldots \ldots \ldots \ldots \ldots \ldots \ldots \ldots \ldots \ldots \ldots \ldots \ldots$

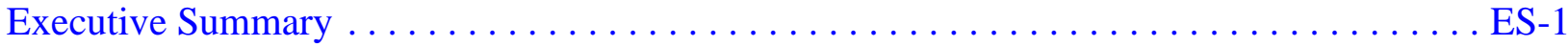

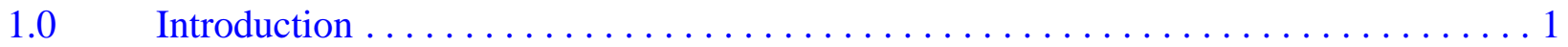

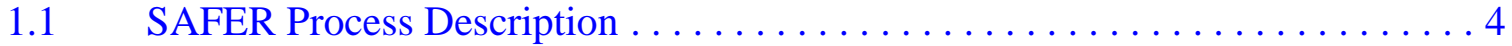

1.2 Summary of Corrective Actions and Closures $\ldots \ldots \ldots \ldots \ldots \ldots \ldots$

$2.0 \quad$ Unit Description. . . . . . . . . . . . . . . . . . . . 11

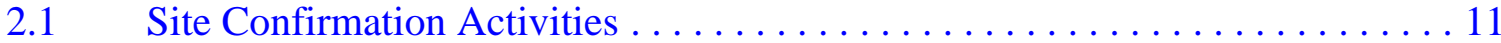

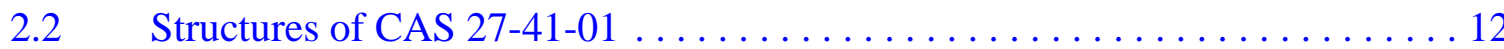

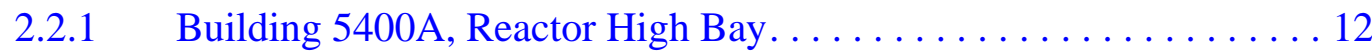

2.2.1.1 History and Process Knowledge . . . . . . . . . . . 15

2.2.1.2 Available Global Information . . . . . . . . . . . . . 15

2.2.2 Building 5400, Reactor Building. . . . . . . . . . . . . . 16

2.2.2.1 History and Process Knowledge . . . . . . . . . 17

2.2.2.2 Available Global Information . . . . . . . . . . . . . 18

2.2.3 Building 5410, Mechanical Building. . . . . . . . . . . . . 19

2.2.3.1 History and Process Knowledge . . . . . . . . . . . . 19

2.2.3.2 Available Global Information .............. 20

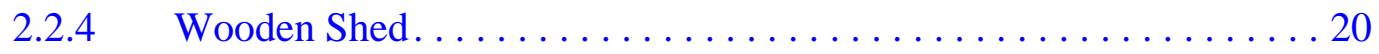

2.2.4.1 History and Process Knowledge . . . . . . . . . . 20

2.2.4.2 Available Global Information . . . . . . . . . . . 21

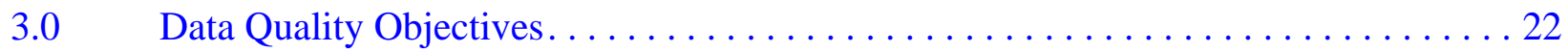

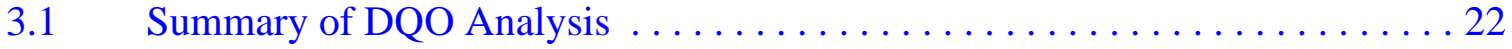

3.1.1 Step 1 - State the Problem . . . . . . . . . . . . . . . . 23

3.1.1.1 Planning Team Members . . . . . . . . . . . . 23

3.1.1.2 Conceptual Site Model . . ............... 23

3.1.1.2.1 Contaminant Release . . . . . . . . . . 27

3.1.1.2.2 Potential Contaminants .............. 28

3.1.1.2.3 Contaminant Characteristics ........... 29

3.1.1.2.4 Site Characteristics .............. 31

3.1.1.2.5 Migration Pathways and Transport

Mechanisms ....................... 31

3.1.1.2.6 Exposure Scenarios . . . . . . . . . . . . 34

3.1.2 Step 2 - Identify Decisions. . . . . . . . . . . . . . . . 34

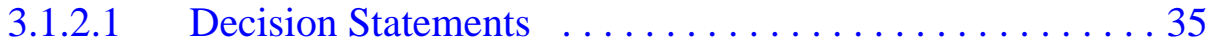

3.1.2.2 Alternative Actions to the Decisions ............ 36 
3.1.3 Step 3 - Identify Inputs to the Decision . . . . . . . . . . . . 36

3.1.3.1 Information Needs . . . . . . . . . . . . . 37

3.1.3.2 Sources of Information $\ldots \ldots \ldots \ldots \ldots \ldots \ldots \ldots \ldots$

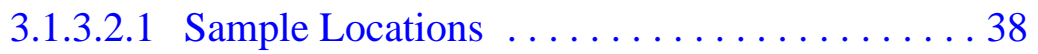

3.1.3.2.2 Analytical Methods ............... 40

3.1.4 Step 4 - Define the Boundaries of the Study . . . . . . . . . . . . . 40

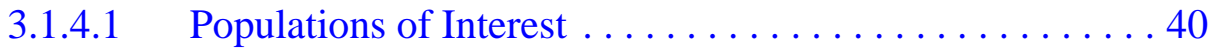

3.1.4.2 Spatial Boundaries . . . . . . . . . . . . . . 43

3.1.4.3 Practical Constraints .................. 44

3.1.4.4 Define the Scale of Decision Making ... . . . . . . . . 44

3.1.5 Step 5 - Develop a Decision Rule . . . . . . . . . . . . . . . . . . . 44

3.1.5.1 Population Parameters ................. 44

3.1.5.2 Decision Rules . . . . . . . . . . . . . . . . 45

3.1.5.3 Soil Sample Action Levels . . . . . . . . . . . . . . . . 45

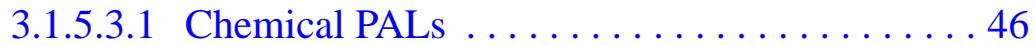

3.1.5.3.2 Radionuclide PALs .............47

3.1.5.4 Measurement and Analysis Sensitivity . . . . . . . . . 47

3.1.6 Step 6 - Specify the Tolerable Limits on Decision Errors . . . . . . . . . 47

3.1.6.1 False Negative Decision Error . . . . . . . . . . . . 48

3.1.6.2 False Positive Decision Error $\ldots \ldots \ldots \ldots \ldots \ldots \ldots$

3.1.7 Step 7 - Optimize the Design. . . . . . . . . . . . . . . 51

3.1.7.1 Corrective Actions for CAS 27-41-01, CAU 118 . . . . . 52

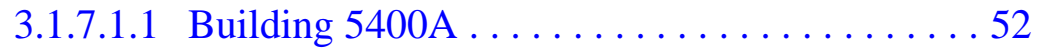

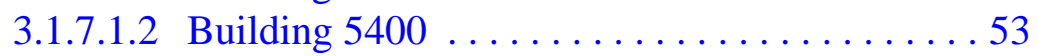

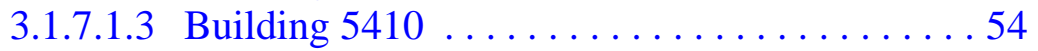

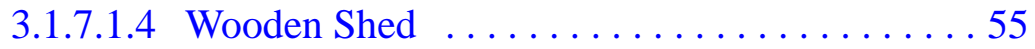

3.1.7.1.5 Ancillary Structures $\ldots \ldots \ldots \ldots \ldots \ldots$

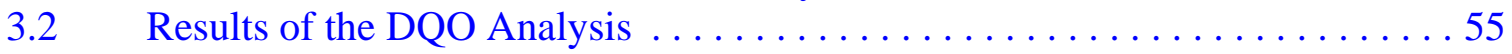

3.2.1 Action Level Determination and Basis . . . . . . . . . . . . 55

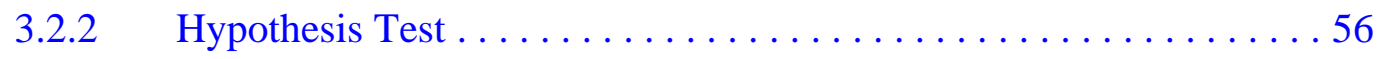

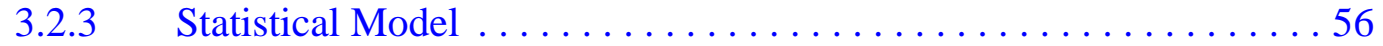

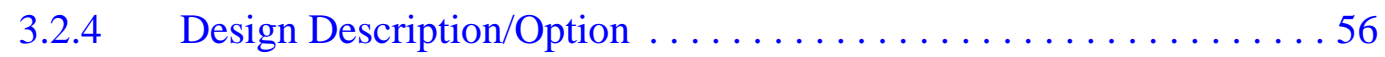

3.2.5 Conceptual Site Model and Drawing. . . . . . . . . . . 56

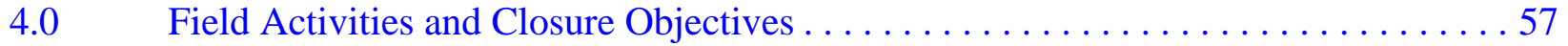

$4.1 \quad$ Contaminants of Potential Concern. . . . . . . . . . . . . . . . . . 58

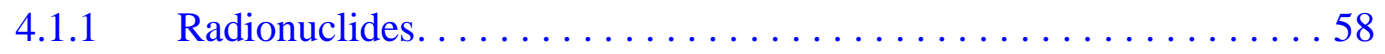

4.1.2 Polychlorinated Biphenyls...................... 59

4.1.3 Resource Conservation and Recovery Act Metals . . . . . . . . . . 59

4.1.3.1 Lead .......................... 59

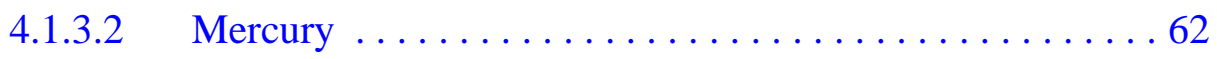




\section{Table of Contents (Continued)}

4.1.3.3 Other RCRA Metals ................6 62

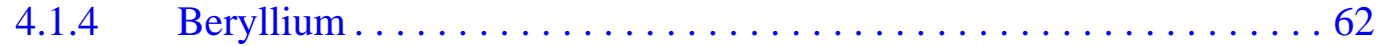

4.1.5 Asbestos-Containing Material . . . . . . . . . . . . . . . . . . 62

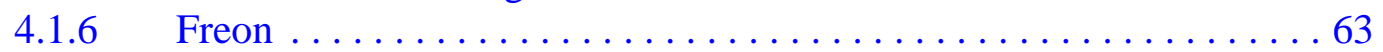

4.1.7 Other Hazardous Constituents . . . . . . . . . . . . . . . . . . . 63

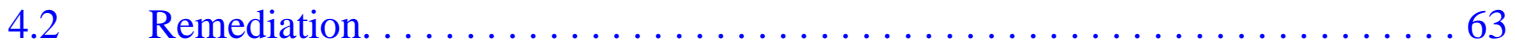

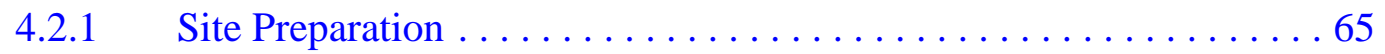

4.2 .2 Site Confirmation. . . . . . . . . . . . . . . . . 66

4.2.3 Draining Lubricants/Fluids from Equipment. . . . . . . . . . . . 66

4.2.4 Hazardous and Regulated Waste Removal . . . . . . . . . . . . . . 66

4.2.4.1 Asbestos Containing Material . . . . . . . . . . . . . 67

4.2.4.2 Resource Conservation and Recovery Act Metals . . . . . 67

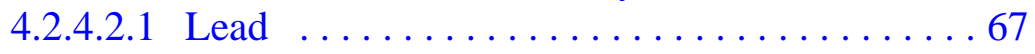

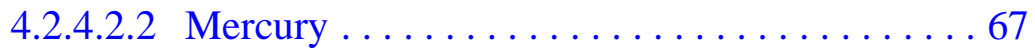

4.2.4.3 Polychlorinated Biphenyls .............. 67

4.2 .5 Placement of Radiologically Impacted Items . . . . . . . . . . . 68

4.2.6 Demolition and Disposal . . . . . . . . . . . . . . . 68

4.2.7 Prepare Structure for Final End-State . . . . . . . . . . . . . 69

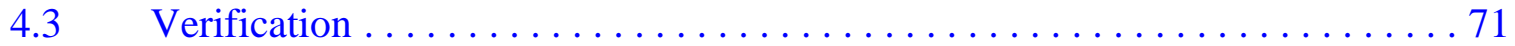

4.3.1 Radiological Surveys . . . . . . . . . . . . . . . . 71

4.3.1.1 Initial Characterization Surveys $\ldots \ldots \ldots \ldots \ldots \ldots 72$

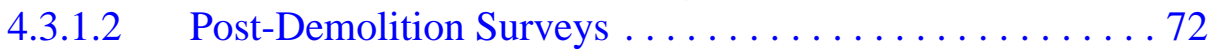

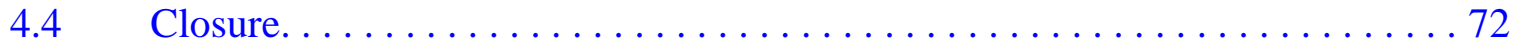

$4.5 \quad$ Duration...................................... 73

$5.0 \quad$ Reports and Records Availability $\ldots \ldots \ldots \ldots \ldots \ldots \ldots \ldots \ldots \ldots \ldots$

$6.0 \quad$ Investigation/Remediation Waste Management $\ldots \ldots \ldots \ldots \ldots \ldots \ldots \ldots \ldots$

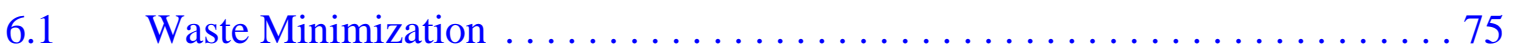

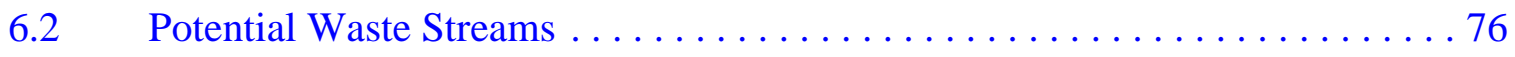

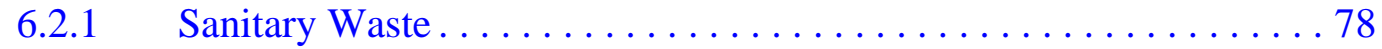

6.2.2 Low-Level Waste. . . . . . . . . . . . . . . . . . . . . . 78

6.2.3 Mixed Low-Level Waste . . . . . . . . . . . . . . . . . . . . 79

6.2 .4 Hazardous Waste . . . . . . . . . . . . . . . . . . 80

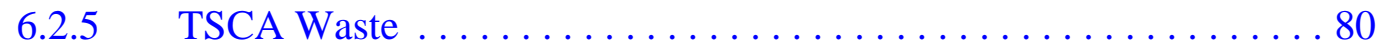

6.2.5.1 Polychlorinated Biphenyls . . . . . . . . . . . 81

6.2.5.2 Asbestos-Containing Material . . . . . . . . . . . 81

6.3 Management of Specific Waste Streams. . . . . . . . . . . . . . 82

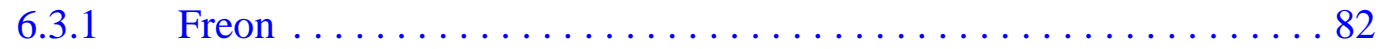

6.3.2 Decontamination Rinsate. .................... 82

6.3.3 Personal Protective Equipment $\ldots \ldots \ldots \ldots \ldots \ldots \ldots \ldots \ldots \ldots$ 


\section{Table of Contents (Continued)}

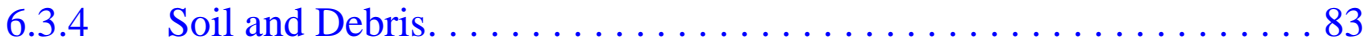

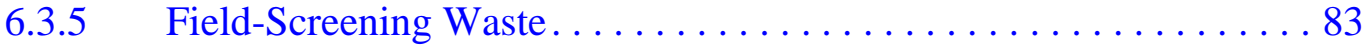

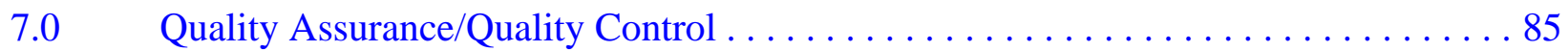

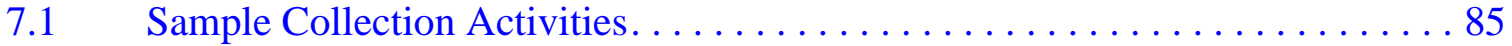

7.2 Applicable Laboratory/Analytical Data Quality Indicators . . . . . . . . . . 86

7.2.1 Precision. . . . . . . . . . . . . . . . . . . . . . . . 88

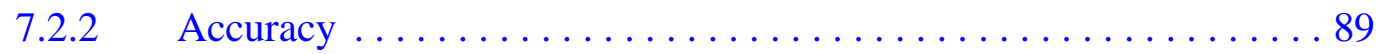

7.2.3 Representativeness........................... 90

7.2.4 Completeness............................ 90

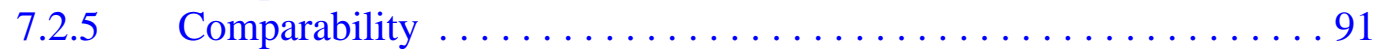

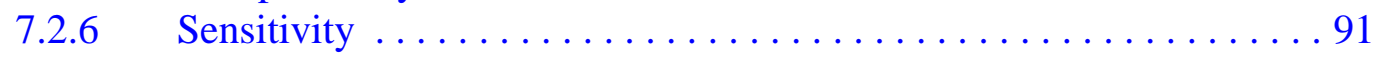

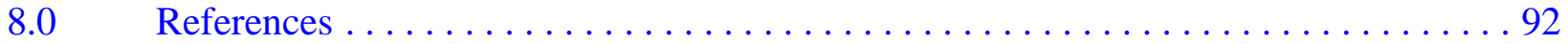

\section{Appendix A - Project Organization}

A.1.0 Project Organization $\ldots \ldots \ldots \ldots \ldots \ldots \ldots \ldots \ldots \ldots \ldots \ldots \ldots \ldots \ldots \ldots \ldots \ldots \ldots \ldots \ldots$

\section{Appendix B - Engineering Drawings for Site Closure}

B.1.0 Engineering Specifications for Site Closure $\ldots \ldots \ldots \ldots \ldots \ldots \ldots \ldots \ldots \ldots$. $\ldots \ldots$

\section{Appendix C - Alternative Evaluation for the Lead Shielding Wall}

C.1.0 Alternative Evaluation for the Lead Shielding Wall . . . . . . . . . . . . . C-1

C.2.0 Development of Corrective Action Alternatives . . . . . . . . . . . . . . C-3

C.2.1 Alternative 1 - Clean Closure . . . . . . . . . . . . . . . . C-3

C.2.2 Alternative 2 - Close in Place with Administrative Controls . . . . . . . . . . C-4

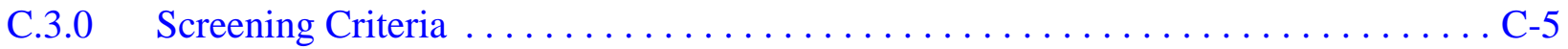

C.3.1 Corrective Action Standards . . . . . . . . . . . . . . . . . . C-5

C.3.2 Remedy Selection Decision Factors $\ldots \ldots \ldots \ldots \ldots \ldots \ldots \ldots \ldots$. . . . . .

C.4.0 Evaluation and Comparison of Alternatives $\ldots \ldots \ldots \ldots \ldots \ldots \ldots \ldots \ldots \ldots$ C-9

C.5.0 Recommended Alternatives......................... C-13

C.6.0 References................................. 


\section{Appendix D - Risk Evaluation of Lead Wall Closure Alternatives}

D.1.0 Introduction $\ldots \ldots \ldots \ldots \ldots \ldots \ldots \ldots \ldots \ldots \ldots \ldots \ldots \ldots \ldots \ldots \ldots \ldots \ldots \ldots \ldots, 1$

D.2.0 Industrial Health and Physical Hazards . . . . . . . . . . . . . . . . . D-3

D.2.1 Health and Safety-Related Hazards Associated with Leaving in Place ..... . . D-3

D.2.2 Health and Safety-Related Hazards Associated with Removal. . . . . . . . . . . . D-3

D.2.2.1 Safety-Related Hazards . . . . . . . . . . . . . . . . . . D-3

D.2.2.2 Health-Related Hazards . . . . . . . . . . . . . . . . . . . . . . D-5

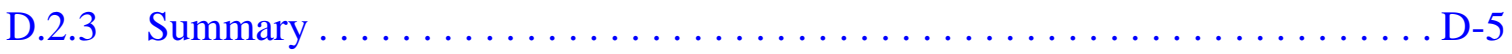

D.3.0 Radiological Hazards. . . . . . . . . . . . . . . . . . . . . . . .

D.3.1 Radiological Hazards Associated with Leaving in Place .............. D-6

D.3.2 Radiological Hazards Associated with Removal ................. D-7

D.3.2.1 External Doses.............................. .

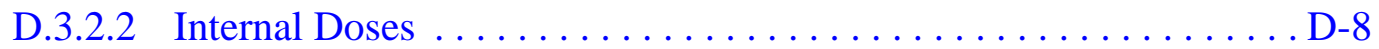

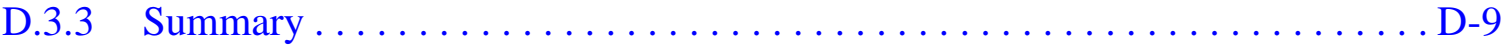

D.4.0 RCRA Regulatory Analysis....................... D

D.4.1 Hazardous Constituents............................ D-10

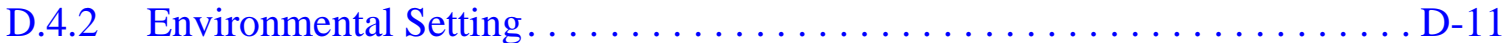

D.4.2.1 NAC 445A.227 ............................ D-11

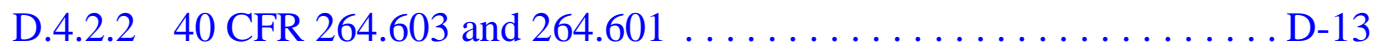

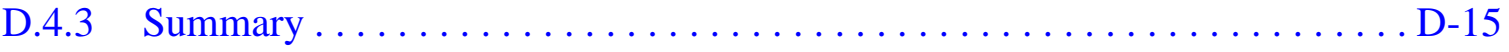

D.5.0 References .................................... D-16

Appendix E - Nevada Division of Environmental Protection Comments 


\section{List of Figures}

Number

Title

Page

1-1 Nevada Test Site Map with CAU 118 CAS Location. . . . . . . . . . . . . 2

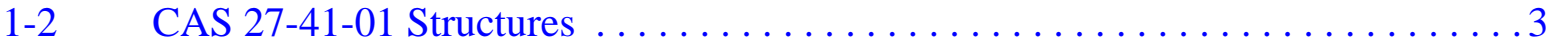

1-3 CAU 118 SAFER Closure Decision Process $\ldots \ldots \ldots \ldots \ldots \ldots \ldots$

3-1 Conceptual Site Model for CAS 27-41-01, CAU 118. . . . . . . . . . 26

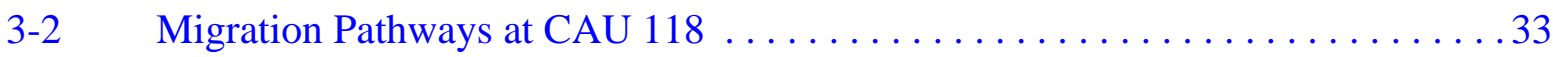

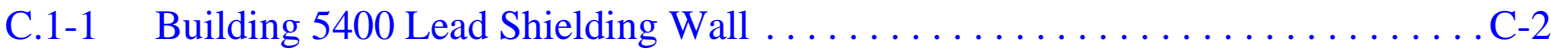




\section{List of Tables}

Number

Title

Page

ES.1-1 Summary of Conceptual Site Model Assumptions and Expected Closures . . . . . 3

2-1 Maximum Radionuclide Activities for Source Material at CAU 118 . . . . . . . 13

2-2 Maximum Chemical Concentrations for Source Material at CAU $118 \ldots \ldots . .14$

3-1 Planning Team Members for CAU 118 May 26, $2006 \ldots \ldots \ldots \ldots \ldots . \ldots . \ldots 24$

3-2 Conceptual Site Model Description of Elements CAS 27-41-01, CAU 118. . . . 27

3-3 CAS 27-41-01, CAU 118 Conceptual Site Model COPCs . . . . . . . . . . . . 29

3-4 Analytes Reported by Analytical Methods . . . . . . . . . . . . . . . 30

3-5 Land-Use and Exposure Scenarios $\ldots \ldots \ldots \ldots \ldots \ldots \ldots \ldots \ldots \ldots \ldots \ldots \ldots \ldots \ldots \ldots \ldots$

3-6 Analytical Requirements for Radionuclides for CAU $118 \ldots \ldots \ldots \ldots \ldots$. . . 41

3-7 Analytical Requirements for Chemical COPCs for CAU $118 \ldots \ldots \ldots \ldots$. . . . 42

4-1 Plans for Disposal of Contaminated Items $\ldots \ldots \ldots \ldots \ldots \ldots \ldots \ldots \ldots \ldots \ldots$

6-1 Waste Management Regulations and Requirements . . . . . . . . . . 77

7-1 Laboratory and Analytical Performance Criteria for

CAU 118 Data Quality Indicators . . . . . . . . . . . . . . . . . . . 87

C.4-1 Ealuation of General Corrective Action Standards . . . . . . . . . . . . C-10

C.4-2 Evaluation of Remedy Selection Decision Factors . . . . . . . . . . . . C-11

D.2-1 Tasks and Estimated Hours Associated with Wall Removal. . . . . . . . . . . D-4

D.3-1 Summary of External Dose Rates for CAU $118 \ldots \ldots \ldots \ldots \ldots \ldots \ldots \ldots$

D.3-2 Summary of External Dose Estimates for CAU $118 \ldots \ldots \ldots \ldots \ldots \ldots \ldots$ D-7

D.3-3 Activation Products for Natural Lead and Stainless Steel. . . . . . . . . . . . . D-9 


\section{List of Acronyms and Abbreviations}

ACM

ASTM

bgs

CAA

CAI

CAS

CAU

CFR

$\mathrm{Cl}$

Co

COC

COPC

$\mathrm{Cr}$

Cs

CSM

D\&D

DOE

DOT

$\mathrm{dpm} / 100 \mathrm{~cm}^{2}$

DQI

DQO

EC

EPA

EQL

$\mathrm{Eu}$

FAL
Asbestos-containing material

American Society for Testing and Materials

Below ground surface

Corrective action alternative

Corrective Action Investigation

Corrective Action Site

Corrective Action Unit

Code of Federal Regulations

Chlorine

Cobalt

Contaminant of concern

Contaminant of potential concern

Chromium

Cesium

Conceptual site model

Decontamination and decommissioning

U.S. Department of Energy

U.S. Department of Transportation

Disintegrations per minute per 100 square centimeters

Data quality indicator

Data quality objective

Environmental Compliance

U.S. Environmental Protection Agency

Estimated quantitation limit

Europium

Final action level 


\section{List of Acronyms and Abbreviations (Continued)}

\begin{tabular}{|c|c|}
\hline $\mathrm{Fe}$ & Iron \\
\hline FFACO & Federal Facility Agreement and Consent Order \\
\hline FI & Field Instruction \\
\hline $\mathrm{ft}$ & Foot \\
\hline $\mathrm{ft}^{2}$ & Square foot \\
\hline FWP & Field Work Permit \\
\hline $\mathrm{H} \& \mathrm{~S}$ & Health and Safety \\
\hline HASL & Health and Safety Laboratory \\
\hline HEPA & High-efficiency particulate air \\
\hline HVAC & Heating, venting, and air conditioning \\
\hline HWAA & Hazardous waste accumulation area \\
\hline IDW & Investigation-derived waste \\
\hline in. & Inch \\
\hline $\mathrm{lb}$ & Pound \\
\hline LCS & Laboratory control sample \\
\hline LCSD & Laboratory control sample duplicate \\
\hline LLW & Low-level waste \\
\hline MDC & Minimum detectable concentration \\
\hline MDL & Minimum detectable level \\
\hline $\mathrm{mg} / \mathrm{kg}$ & Milligrams per kilogram \\
\hline $\mathrm{mg} / \mathrm{L}$ & Milligrams per liter \\
\hline $\mathrm{mi}$ & Mile \\
\hline MLLW & Mixed low-level waste \\
\hline $\mathrm{M} \& \mathrm{O}$ & Management and operating \\
\hline mrem & Millirem \\
\hline $\mathrm{mrem} / \mathrm{yr}$ & Millirem per year \\
\hline
\end{tabular}




\section{List of Acronyms and Abbreviations (Continued)}

MS Matrix spike

MSD Matrix spike duplicate

N/A Not applicable

NAC Nevada Administrative Code

NCRP National Council on Radiation Protection and Measurements

ND Normalized difference

NDEP Nevada Division of Environmental Protection

$\mathrm{Ni} \quad$ Nickel

NNSA/NSO U.S. Department of Energy, National Nuclear Security Administration Nevada Site Office

NRS Nevada Revised Statutes

NTS Nevada Test Site

NTSWAC Nevada Test Site Waste Acceptance Criteria

NV/YMP Nevada/Yucca Mountain Project

OSHA Occupational Safety and Health Administration

$\mathrm{Pb} \quad$ Lead

PCB Polychlorinated biphenyl

$\mathrm{pCi} / \mathrm{g} \quad$ Picocuries per gram

pCi/L Picocuries per liter

$\mathrm{pCi} / \mathrm{mL} \quad$ Picocuries per milliliter

POC Performance Objective for the Certification of Nonradioactive Hazardous Waste

PPE Personal protective equipment

PRG Preliminary remediation goal

$\mathrm{Pu} \quad$ Plutonium

QA Quality assurance

QAPP Quality Assurance Project Plan

QC Quality control 


\section{List of Acronyms and Abbreviations (Continued)}

\begin{tabular}{|c|c|}
\hline RadCon & Radiological Control \\
\hline RBCA & Risk-based corrective action \\
\hline RCA & Radiologically controlled area \\
\hline RCRA & Resource Conservation and Recovery Act \\
\hline RCT & Radiological Control Technician \\
\hline $\mathrm{RL}$ & Reporting limit \\
\hline RMA & Radioactive material area \\
\hline R-MAD & Reactor Maintenance, Assembly, and Disassembly \\
\hline RPD & Relative percent difference \\
\hline RWP & Radiological Work Permit \\
\hline SAFER & Streamlined Approach for Environmental Restoration \\
\hline SAP & Sampling and Analysis Plan \\
\hline SNJV & Stoller-Navarro Joint Venture \\
\hline $\mathrm{Sr}$ & Strontium \\
\hline SSTL & Site-specific target level \\
\hline SVOC & Semivolatile organic compound \\
\hline TBD & To be determined \\
\hline TSCA & Toxic Substances Control Act \\
\hline $\mathrm{U}$ & Uranium \\
\hline UGTA & Underground Test Area \\
\hline VOC & Volatile organic compound \\
\hline WM & Waste Management \\
\hline WMP & Waste Management Plan \\
\hline$\% \mathrm{R}$ & Percent recovery \\
\hline$\mu g / \mathrm{kg}$ & Micrograms per kilogram \\
\hline
\end{tabular}




\section{Executive Summary}

This Streamlined Approach for Environmental Restoration (SAFER) plan addresses closure for Corrective Action Unit (CAU) 118, Area 27 Super Kukla Facility, identified in the Federal Facility Agreement and Consent Order. Corrective Action Unit 118 consists of one Corrective Action Site (CAS), 27-41-01, located in Area 27 of the Nevada Test Site. Corrective Action Site 27-41-01 consists of the following four structures:

- Building 5400A, Reactor High Bay

- Building 5400, Reactor Building and access tunnel

- Building 5410, Mechanical Building

- Wooden Shed, a.k.a. "Brock House"

This plan provides the methodology for field activities needed to gather the necessary information for closing the CAS. There is sufficient information and process knowledge from historical documentation and site confirmation data collected in 2005 and 2006 to recommend closure of CAU 118 using the SAFER process.

The Data Quality Objective process developed for this CAU identified the following expected closure option: closure in place with use restrictions. This expected closure option was selected based on available information including contaminants of potential concern, future land use, and assumed risks.

There are two decisions that need to be answered for closure. Decision I is to determine the nature of contaminants of concern in environmental media or potential source material that could impact human health or the environment. Decision II is to determine whether or not sufficient information has been obtained to confirm that closure objectives were met. This decision includes determining whether the extent of any contamination remaining on site has been defined, and whether actions have been taken to eliminate exposure pathways.

The following text summarizes the types of activities that will support the closure of CAU 118:

- Site preparation (e.g., installation of temporary power, lighting, and ventilation; Hantavirus cleanup). 
- $\quad$ Site confirmation, including:

- Collection of building media characterization samples.

- Collection of radiological surveys, smears, and health and safety swipes, and air monitoring data.

- Inventory of loose debris present in each structure.

- Removal of oils (polychlorinated biphenyl [PCB] and non-PCB) from hydraulic system and equipment.

- Removal of hazardous and regulated materials, including:

- Lead (electrical components, batteries)

- Mercury (switches)

- Asbestos-containing material

- PCBs (fluids/lubricants)

- Freon from heating, venting, and air conditioning systems

- $\quad$ Placement of debris from Building 5410 and the Wooden Shed identified during the inventory into Building 5400.

- Demolition of Buildings 5400A and 5410 to slab, and appropriate disposal of construction materials.

- Demolition of the Wooden Shed to grade, and appropriate disposal of construction materials.

- Stabilization of Building 5400 (access tunnel, reactor room, basement, and sump) by filling the structure and contents with flowable grout.

- Implementation of engineering specifications, as necessary, to protect the subsurface structure from infiltration and weathering.

- Performance of final release and confirmatory radiological surveys to establish proper controls (postings) of concrete foundations.

- Installation of radiological postings and use restrictions, as necessary.

- Documentation of all closure activities for CAU 118 in a Closure Report.

Historical information, process knowledge, and site confirmation data collected in 2006 identified sources of potential contamination for each of the structures on site. See Table ES.1-1 for a summary of the conceptual site model assumptions and expected closure strategy. 
Under the Federal Facility Agreement and Consent Order, the SAFER plan will be submitted to the Nevada Division of Environmental Protection (NDEP) for approval. Field work will be conducted following approval of the plan. On completion of the field activities, a Closure Report will be prepared and submitted to the NDEP for review and approval.

Table ES.1-1

Summary of Conceptual Site Model Assumptions and Expected Closures

\begin{tabular}{||c|c|c|c||}
\hline CAS & $\begin{array}{c}\text { Potential Release of } \\
\text { COPCs }\end{array}$ & $\begin{array}{c}\text { Conceptual Site Model } \\
\text { Assumptions }\end{array}$ & $\begin{array}{c}\text { Expected } \\
\text { Closure }\end{array}$ \\
\hline \hline $27-41-01$ & $\begin{array}{c}\text { Buildings 5400, 5400A, and } \\
5410 \text { media, structure, and } \\
\text { contents; debris stored in } \\
\text { the Wooden Shed }\end{array}$ & $\begin{array}{c}\text { Limited lateral and vertical movement } \\
\text { of contaminants in surface or shallow } \\
\text { subsurface soils }\end{array}$ & $\begin{array}{c}\text { Close in place with } \\
\text { use restriction }\end{array}$ \\
\hline
\end{tabular}

CAS $=$ Corrective action site

$\mathrm{COPC}=$ Contaminant of potential concern 


\subsection{Introduction}

This Streamlined Approach for Environmental Restoration (SAFER) plan addresses the actions necessary for the closure of Corrective Action Unit (CAU) 118, Area 27 Super Kukla Facility, Nevada Test Site (NTS), Nevada. It has been developed in accordance with the Federal Facility Agreement and Consent Order (FFACO) (1996) that was agreed to by the State of Nevada, the U.S. Department of Energy (DOE), and the U.S. Department of Defense.

A SAFER may be performed when the following criteria are met:

- Conceptual corrective actions are clearly identified. Some degree of investigation may be necessary to select a specific corrective action before completion of the Corrective Action Investigation (CAI).

- Uncertainty of the nature, extent, and corrective action must be limited to an acceptable level of risk.

- The SAFER plan includes decision points and criteria for making Data Quality Objective (DQO) decisions.

The purpose of the SAFER plan will be to document and verify the adequacy of existing information; affirm the decision for either clean closure, closure in place, or no further action; and provide sufficient data to implement the corrective action. The corrective action alternative presented in this SAFER plan was selected based on existing information and analytical data collected at the site in early 2006. Any additional data gaps will be addressed and incorporated into the decision process. This SAFER plan also identifies decision points developed in cooperation with the Nevada Department of Environmental Protection (NDEP), where the DOE, National Nuclear Security Administration Nevada Site Office (NNSA/NSO) will reach consensus with the NDEP before beginning the next phase of work (see Figure 1-3).

Corrective Action Unit 118 is located in Area 27 of the NTS, which is approximately 60 miles (mi) northwest of Las Vegas, Nevada (Figure 1-1). Corrective Action Unit 118 is comprised of one 


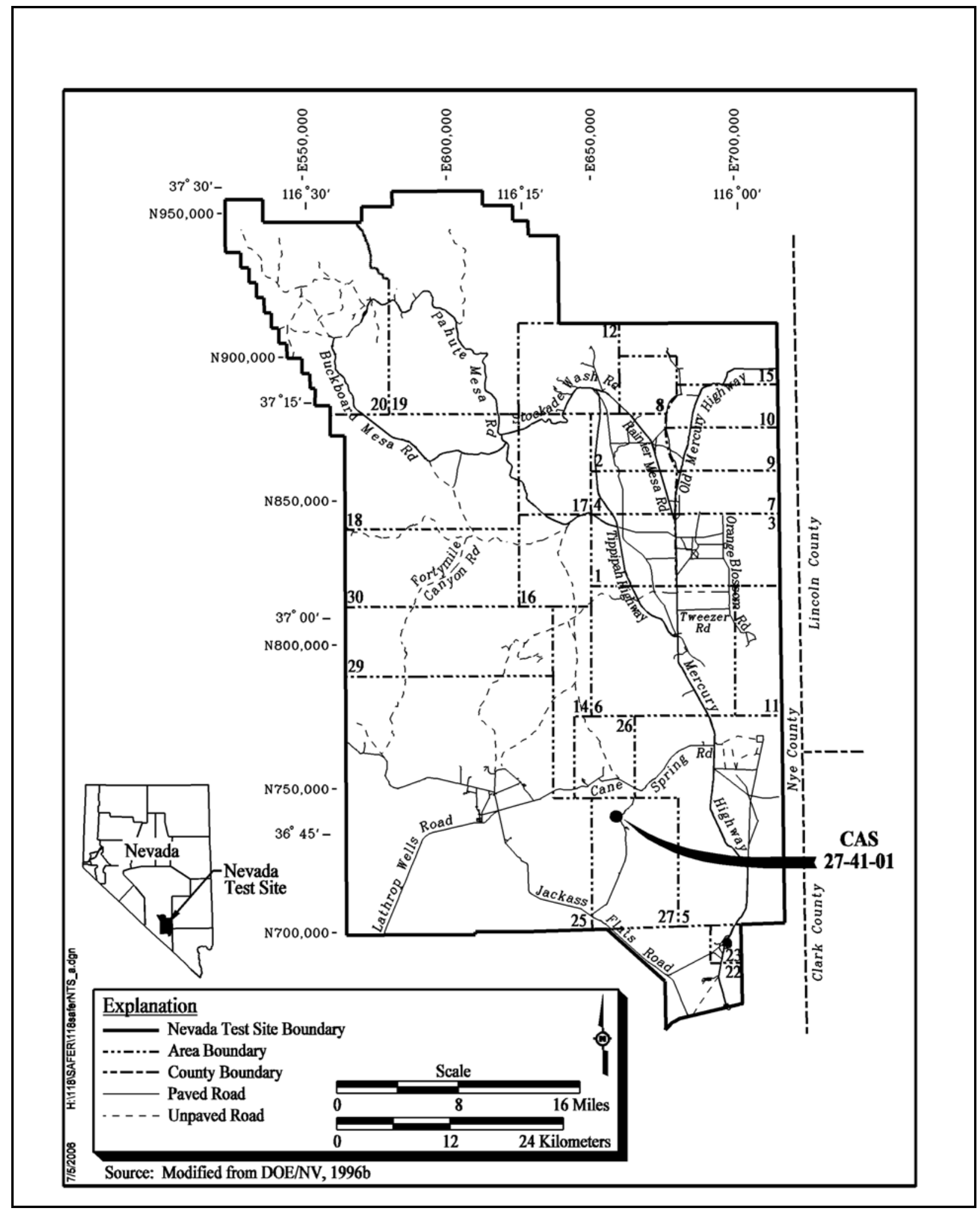

Figure 1-1

Nevada Test Site Map with CAU 118 CAS Location 


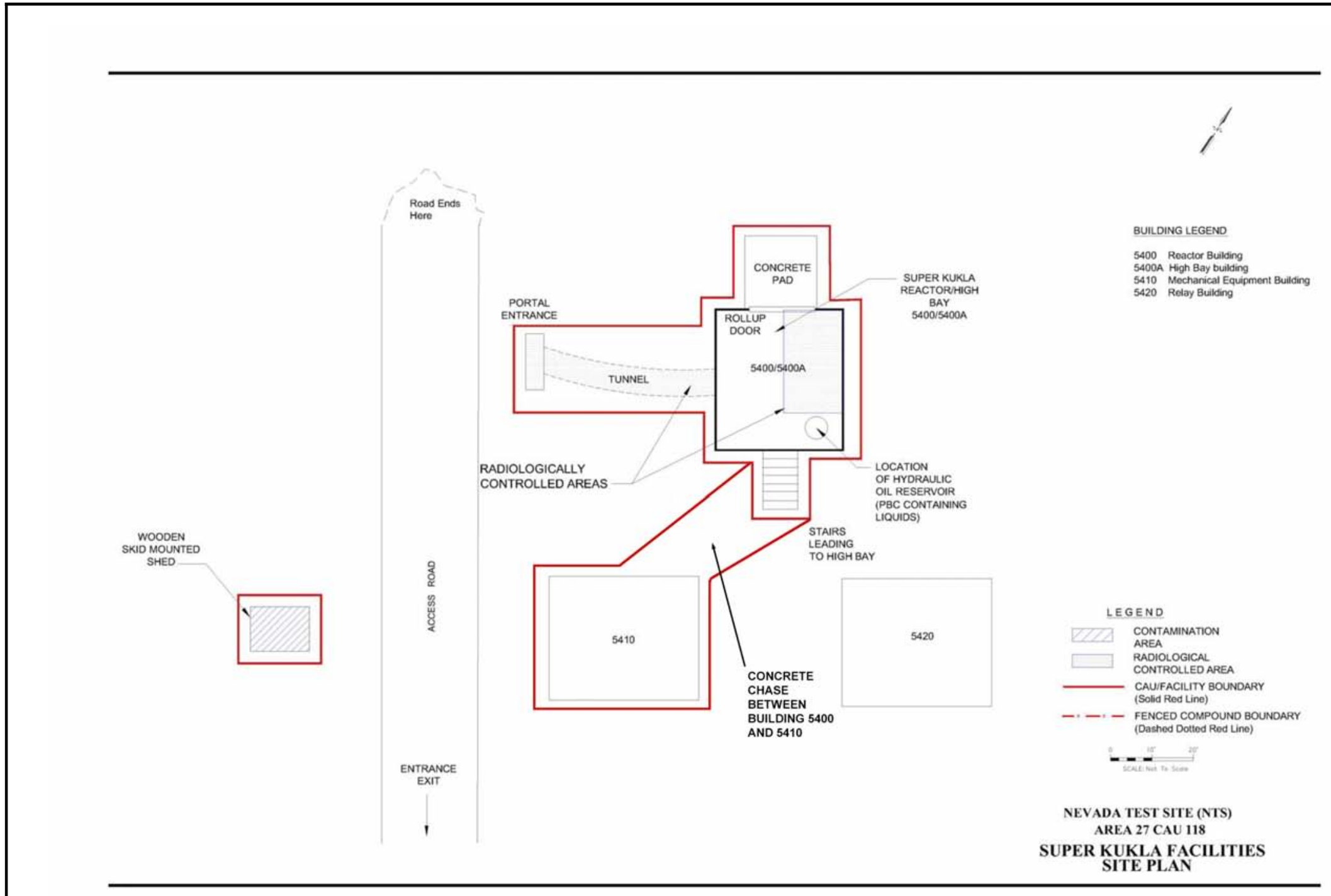

Source: Adapted from Holmes \& Narver, Inc., date unknown

Figure 1-2

CAS 27-41-01 Structures 
Corrective Action Site (CAS), CAS 27-41-01, as shown on Figure 1-1. Corrective Action Site 27-41-01 is comprised of the four structures listed below and shown in Figure 1-2:

- Building 5400A, Reactor High Bay

- Building 5400, Reactor Building and access tunnel

- Building 5410, Mechanical Building

- Wooden Shed, a.k.a. "Brock House"

Building 5420, the Relay Building, was previously demolished to slab and is not in the scope of CAS 27-41-01.

There is sufficient information and process knowledge from historical documentation and investigations of similar sites (i.e., the expected nature and extent of contaminants of potential concern [COPCs]) to recommend closure of CAU 118 using the SAFER process (FFACO, 1996).

\subsection{SAFER Process Description}

Corrective action units that may be closed using the SAFER process have conceptual corrective actions that are clearly identified. Consequently, corrective action alternatives can be chosen before completing a CAI, given anticipated investigation results.

The SAFER process combines elements of the DQO process and the observational approach to plan and conduct closure activities. The DQOs are used to identify the problem and define the type and quality of data needed to complete closure of each CAS. The purpose of the investigation phase is to verify the adequacy of existing information used to determine the chosen corrective action and to confirm that closure objectives were met.

Use of the SAFER process allows for technical decisions to be made based on incomplete but sufficient information and the experience of the decision maker. Based on a detailed review of historical documentation and site confirmation data collected in early 2006, there is sufficient process knowledge and analytical information to close CAU 118 using the SAFER process. Any uncertainties are addressed by documented assumptions that are verified by sampling and analysis, data evaluation, and on-site observations, as necessary. Closure activities may proceed simultaneously with site characterization as sufficient data are gathered to confirm or disprove the assumptions made during selection of the corrective action. If, at any time during the closure process, 
new information is discovered that indicates that closure activities should be revised, closure activities will be re-evaluated as appropriate.

\subsection{Summary of Corrective Actions and Closures}

The primary objective of the closure strategy proposed for CAU 118 is to eliminate or reduce risks to human health and the environment through limited removal of source materials or contaminated environmental media, facility stabilization, and control of exposure pathways through a Use Restriction.

The proposed final end-state of the CAS is Closure in Place with Use Restrictions. Additional objectives of this closure strategy are to (1) verify that the chosen corrective action is appropriate and effective, (2) minimize the potential for future exposures, (3) remove potentially hazardous source materials as practical, (4) reduce facility liability, and (5) reduce the need for long-term surveillance and maintenance costs.

Closure of CAU 118 will be accomplished by completing activities as part of a six-phase plan:

- $\quad$ Phase I: Site Preparation (completed)

- Install temporary power, office trailer, lighting, and ventilation (complete).

- Clean on-site structures for Hantavirus (ongoing, as necessary).

- $\quad$ Phase II: Site Confirmation (partially completed)

- Collect building media samples such as concrete and paint chips (ongoing).

- Collect radiological surveys, smears and health and safety (H\&S) swipes, and air monitoring data (ongoing).

- Inventory material and debris in each building (ongoing).

- $\quad$ Phase III: DQO/SAFER Process

- Establish DQO criteria and develop SAFER plan.

- $\quad$ Phase IV: Hazard Reduction/Waste Management

- Remove polychlorinated biphenyl (PCB) and non-PCB oils, lead and mercury components, asbestos, and other hazardous materials, as practical. 
- Place debris from Building 5410 and the Wooden Shed in Building 5400 for entombment, as appropriate.

- Phase V: Demolition, Disposal and Final Investigation

- Demolish and dispose of Buildings 5400A and 5410 and their contents to their concrete slabs.

- Demolish and dispose of Wooden Shed to grade.

- Sample soils adjacent to the Building 5410 slab and from under the Wooden Shed.

- Survey Building 5400A and Building 5410 concrete slabs.

- $\quad$ Phase VI: Prepare Structure for Final End-State

- Fill openings and pathways (e.g., ducts, sumps, overpressure well) with grout and/or concrete.

- Fill and entomb Building 5400 — including sumps, basement reactor room — and tunnel with flowable grout.

- Implement engineering specifications to prevent weathering and precipitation infiltration (i.e., grade surrounding area to ensure surface water flows away from buildings).

- Apply appropriate Use Restriction.

This closure strategy also assumes the following:

- $\quad$ Liquid and hazardous wastes will be removed to the extent practical (e.g., oils and mercury switches to be removed, the lead shielding wall to remain in place). See Appendix $C$ and Appendix D for qualitative and quantitative discussions, respectively, on the justification for leaving lead in place.

- Solid debris from Buildings 5400A, 5410, and the Wooden Shed generated during Phase V will be placed in Building 5400 for entombment during Phase VI.

- There is not a complete pathway from CAS 27-41-01 to groundwater.

- The end-state for the site will require implementation of Use Restrictions for final closure.

- Building debris from demolition activities will be managed appropriately and disposed of according to applicable regulatory requirements and as specified in Section 6.0. 
The proposed end-state for each of the structures is described below:

- $\quad$ Building 5400A, High Bay

- Hazardous and mixed wastes (e.g., lead, mercury, asbestos-containing material [ACM]) will be stripped out and disposed of appropriately.

- The building structure - including the shell; heating, ventilating, and air conditioning (HVAC); and stacks — will be demolished to slab and disposed of on site (at NTS).

- The remaining concrete slab will be surveyed and posted according to the NV/YMP Radiological Control (RadCon) Manual (NNSA/NSO, 2004).

- Building 5400, Reactor Building

- Liquids, gases, and hazardous wastes will be removed and disposed of appropriately, except where removal is not practical (see Table 4-1).

- Debris from Buildings 5410 and the Wooden Shed may be placed in Building 5400 for entombment if it is determined to be compatible (i.e., the debris is not hazardous or mixed waste, consists of the same radionuclides, and will not increase void space after entombment).

- All ventilation and the hydraulic line chase connecting Buildings 5400 and 5410 will be filled with flowable grout.

- The overpressure well will be filled with flowable grout.

- The basement, stairwell, sump, and lower portion of the reactor stand and associated systems will be filled with flowable grout.

- The reactor room and all associated debris and fixtures will be filled from a 3-foot (ft) access port in the ceiling of the reactor room (High Bay floor). The reactor stand, lead wall, and any associated activated or contaminated solid media (e.g., tools, equipment, electronics, test canisters) will be left in the room and filled in place. See Appendix C and Appendix D for qualitative and quantitative discussions, respectively, on the justification for leaving lead in place. Void spaces within the structure will be filled.

- The access tunnel to Building 5400 and all associated debris and fixtures from the reactor room will be filled to the tunnel entrance. The entrance to the tunnel will be sealed closed.

- Engineering specifications to prevent weathering and precipitation infiltration (i.e., grade surrounding the area to ensure surface water flows away from buildings) will be implemented. 
- Building 5410, Mechanical Building

- Contents will be stripped out and either disposed of or placed in Building 5400 for entombment, as appropriate.

- The structure will be demolished to slab. Structure material will be disposed of appropriately.

- The remaining concrete slab will be surveyed and posted according to the NV/YMP RadCon Manual (NNSA/NSO, 2004).

- Wooden Shed

- Contents will be stripped out and either disposed of or placed in Building 5400 for entombment, as appropriate.

- The structure will be demolished to grade. Structure material will be disposed of appropriately.

- It will be verified that no contamination exists in soil underneath the shed. Soils will either be less than the final action levels (FALs) or included in the Use Restriction.

- Ancillary Structures

- It is proposed that concrete stairs and railings, perimeter fencing, bollards, and turnstiles will be removed.

The decision process for closure of CAU 118 is summarized in Figure 1-3. This process starts with the initial investigation in which the appropriate target population(s) within each CAS (defined in the DQO process, Section 3.0) is sampled. If contaminants in surrounding soils are detected at concentrations that are above the FALs and remediation is feasible, the contamination will be removed. Otherwise, the extent of contamination will be delineated by additional sampling, and appropriate Use Restrictions will be put in place. Contingencies are built into the process in the event new information is identified indicating that the selected closure option should be revised. The process ends with closure of the site based on laboratory analytical results of the environmental samples, execution of the approved closure actions and the preparation of a Closure Report.

Decision points which require a consensus be reached between the NNSA/NSO and the NDEP before continuing are indicated in Figure 1-3. 


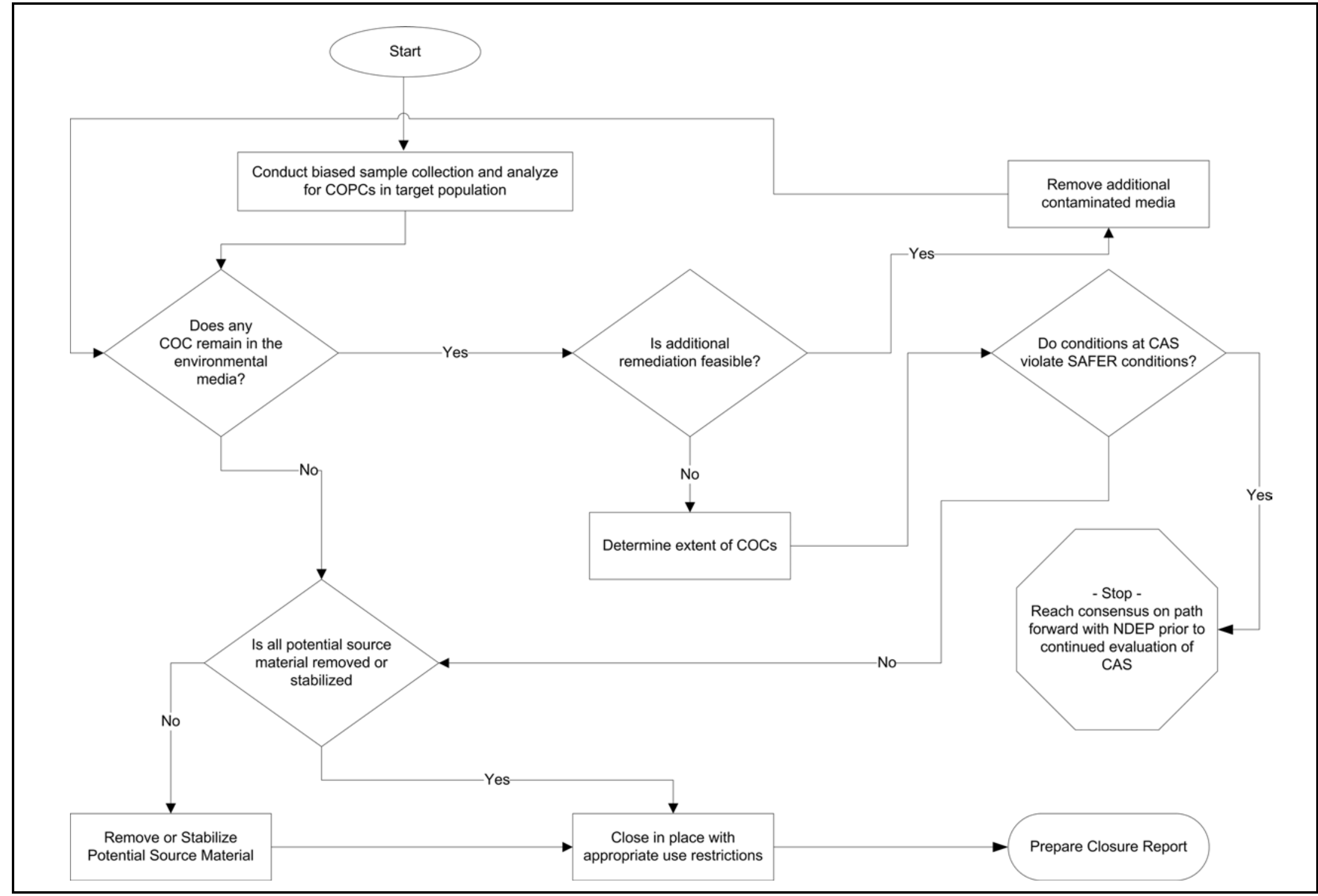

Figure 1-3

CAU 118 SAFER Closure Decision Process 
In addition to the previously discussed hold/decision points, work may be temporarily suspended until the issue can be satisfactorily resolved if any of the following unexpected conditions occur:

- Conditions outside the scope of work are encountered.

- Radiological screening yields results that require an upgrade in procedures to continue work in specific areas.

- Elevated levels of additional COCs are found that were not originally identified as being present at the site.

- Unexpected conditions, including unexpected waste and/or contamination, are encountered.

- Out-of-scope work activities are required due to the detection of other contaminants of concern (COCs) that would require re-evaluating a disposal pathway, such as with hazardous or low-level waste (LLW).

- Unsafe conditions or work practices exist. 


\subsection{Unit Description}

Corrective Action Unit 118 is located within Area 27 of the NTS (see Figure 1-1), and is comprised of one CAS, CAS 27-41-01. Four structures are located at CAS 27-41-01:

- Building 5400A, Reactor High Bay

- Building 5400, Reactor Building and access tunnel

- Building 5410, Mechanical Building

- Wooden Shed, a.k.a. "Brock House"

The reactor was built in 1964 and operated from 1964 until 1979 to test the effects of "prompt bursts" (intense pulses of radiation) on samples of fissile and other materials. Operation of the reactor involved bringing two sections of the reactor together using a hydraulic system to create the prompt bursts. In 1979, tests at the reactor were halted and the reactor core was disassembled. At that time, D\&D activities took place in Buildings 5400, 5400A, and 5410 (DOE/NV, 1993a). Access to Buildings 5400 and 5400A is limited by an interior security fence with personnel gates. Structures associated with the Super Kukla Facility (including a Relay Building, which has already been demolished to slab) cover an area of approximately 2 acres (NPS, 2000). An exterior wire fence surrounds the CAS.

Operational history, process knowledge, and analytical data gathered during the site confirmation phase for CAS 27-41-01 are summarized in the sections below for each of the structures associated with Super Kukla. Process knowledge has been obtained through historical document reviews, engineering drawing and map reviews, and interviews with past and present NTS employees. Based on this process knowledge and analytical information obtained during site confirmation activities in 2006, assumptions were made to formulate a conceptual site model (CSM) that describes the most probable scenario for the current conditions at the CAS. Section 3.1.1.2 provides additional information on the CSM.

\subsection{Site Confirmation Activities}

In order to supplement the existing historical data, Stoller-Navarro Joint Venture (SNJV) conducted field investigations in late 2005 and early 2006, during which various types of field screening activities were performed, referenced herein as the "Site Confirmation." During the Site 
Confirmation, more than 100 media samples were collected and analyzed. These efforts involved the systematic sampling of surface soils surrounding Building 5400 and various building media of Buildings 5400 and 5400A, including concrete, steel, paint, insulation, high-efficiency particulate air (HEPA) filters, oils, and suspected ACM. Radiological swipes and direct readings were also collected, analyzed, and documented.

The media were analyzed for a wide range of radiological and chemical contaminants respective of the process knowledge of facility operations and building contents. Maximum detected activities and concentrations are listed in Tables 2-1 and 2-2 by location and media type, respectively. In these tables, Building 5400A includes samples taken on the interior and exterior of Building 5400A, and Building 5400 includes the overpressure well, access tunnel, reactor room east and west of the lead wall, basement, sump, and surrounding soil. (The analytical parameters of the Site Confirmation are detailed in Table 3-3.) A discussion of these findings is presented in Section 2.2.

Waste inventories for the contents of Buildings 5400, 5400A, and the Wooden Shed were performed during the Site Confirmation. Following Hantavirus cleanup, a waste inventory and radiological survey of the contents of Building 5410 will be performed.

Data obtained from the Site Confirmation will be used for waste management determinations and to support the selection of Closure in Place as the corrective action recommended in this SAFER document. Data from the facility's adjacent soils will be used to determine the nature and extent of potential activation and contamination in the soil, if present, in accordance with the DQO process in Section 3.0.

\subsection{Structures of CAS 27-41-01}

\subsubsection{Building 5400A, Reactor High Bay}

Building 5400A (High Bay) is located directly above Building 5400 and is connected to 5400 via a 3-ft-diameter concrete plug in the floor. A steel plate normally covering the reactor trapdoor has been removed to allow for ventilation of the Reactor Building through the High Bay. Exterior walls are constructed of corrugated aluminum over a steel frame. The interior features smooth metal painted walls and the exposed structural steel frame. The High Bay floor is comprised of high-density, 
Table 2-1

Maximum Radionuclide Activities for Source Material at CAU 118

\begin{tabular}{|c|c|c|c|c|c|c|c|c|c|c|c|c|c|}
\hline Location & Sample Media & Co-60 & Cs-137 & Eu-152 & Eu-155 & Fe-55 & Tritium & $\mathrm{Ni}-63$ & Pu-239 & Sr-90 & U-234 & U-235 & U-238 \\
\hline \multirow{8}{*}{$\begin{array}{l}\text { Building } \\
5400^{\mathrm{a}}\end{array}$} & Concrete $(\mathrm{pCi} / \mathrm{g})^{\mathrm{c}}$ & 0.7 & $<\mathrm{MDL}$ & 25 & $<M D L$ & $<M D L$ & $\begin{array}{c}1,560 \\
(\mathrm{pCi} / \mathrm{mL})\end{array}$ & $<\mathrm{MDL}$ & $<\mathrm{MDL}$ & $<\mathrm{MDL}$ & $<\mathrm{MDL}$ & $<M D L$ & $<\mathrm{MDL}$ \\
\hline & Liquid (pCi/L) & $<\mathrm{MDL}$ & $<\mathrm{MDL}$ & $<\mathrm{MDL}$ & $<\mathrm{MDL}$ & $<\mathrm{MDL}$ & 1,440 & $<\mathrm{MDL}$ & $<\mathrm{MDL}$ & $<\mathrm{MDL}$ & 0.5 & $<\mathrm{MDL}$ & 0.129 \\
\hline & Metal Solid (pCi/g) & 53.6 & $<\mathrm{MDL}$ & $<\mathrm{MDL}$ & $<\mathrm{MDL}$ & 700 & $<\mathrm{MDL}$ & 290 & $<\mathrm{MDL}$ & $<\mathrm{MDL}$ & $<\mathrm{MDL}$ & $<\mathrm{MDL}$ & $<\mathrm{MDL}$ \\
\hline & $\begin{array}{c}\text { Crane/ Robotic Arm } \\
\text { Oil (pCi/g) }\end{array}$ & $<\mathrm{MDL}$ & $<\mathrm{MDL}$ & $<M D L$ & $<M D L$ & $<\mathrm{MDL}$ & $<M D L$ & $<M D L$ & $<\mathrm{MDL}$ & $<\mathrm{MDL}$ & $<\mathrm{MDL}$ & $<\mathrm{MDL}$ & $<\mathrm{MDL}$ \\
\hline & $\begin{array}{c}\text { Basement } \\
\text { Sump/Tank Oil } \\
(p C i / g)\end{array}$ & $<M D L$ & $<\mathrm{MDL}$ & $<\mathrm{MDL}$ & $<M D L$ & $<\mathrm{MDL}$ & $<M D L$ & $<M D L$ & 0.028 & $<\mathrm{MDL}$ & 0.114 & $<\mathrm{MDL}$ & $<M D L$ \\
\hline & Paint Chip (pCi/g) & 15.4 & 4.31 & 4.39 & $<M D L$ & $<\mathrm{MDL}$ & $\begin{array}{c}271 \\
(\mathrm{pCi} / \mathrm{mL})\end{array}$ & $<M D L$ & $<M D L$ & 27.5 & 272 & 23.9 & 7.5 \\
\hline & Soil (pCi/g) & $<\mathrm{MDL}$ & 0.37 & & $<\mathrm{MDL}$ & $<\mathrm{MDL}$ & $<\mathrm{MDL}$ & $<\mathrm{MDL}$ & $<\mathrm{MDL}$ & $<\mathrm{MDL}$ & $<\mathrm{MDL}$ & $<\mathrm{MDL}$ & $<\mathrm{MDL}$ \\
\hline & $\begin{array}{l}\text { Surface Swipe } \\
\text { (pCi/sample) }\end{array}$ & $<\mathrm{MDL}$ & 100 & $<\mathrm{MDL}$ & 72 & $<M D L$ & $<\mathrm{MDL}$ & $<M D L$ & 0.81 & 75 & 14,100 & 1,060 & 301 \\
\hline \multirow{3}{*}{$\begin{array}{l}\text { Building } \\
5400 A^{b}\end{array}$} & Filter (pCi/g) & $<\mathrm{MDL}$ & 2.66 & $<\mathrm{MDL}$ & & $<\mathrm{MDL}$ & $<\mathrm{MDL}$ & $<\mathrm{MDL}$ & 0.066 & 1.49 & 12 & 0.81 & 0.46 \\
\hline & Metal Solid (pCi/g) & 0.24 & $<\mathrm{MDL}$ & $<\mathrm{MDL}$ & & $<\mathrm{MDL}$ & $<\mathrm{MDL}$ & $<\mathrm{MDL}$ & $<\mathrm{MDL}$ & $<\mathrm{MDL}$ & $<\mathrm{MDL}$ & $<\mathrm{MDL}$ & $<\mathrm{MDL}$ \\
\hline & $\begin{array}{r}\text { Surface Swipe } \\
\text { (pCi/ sample) }\end{array}$ & $<M D L$ & $<\mathrm{MDL}$ & $<\mathrm{MDL}$ & & $<M D L$ & $<\mathrm{MDL}$ & $<\mathrm{MDL}$ & $<M D L$ & $<\mathrm{MDL}$ & 2.84 & $<\mathrm{MDL}$ & 0.141 \\
\hline $\begin{array}{c}\text { Building } \\
5410\end{array}$ & $\mathrm{TBD}^{\mathrm{d}}$ & $\mathrm{TBD}^{\mathrm{d}}$ & $\mathrm{TBD}^{\mathrm{d}}$ & $\mathrm{TBD}^{\mathrm{d}}$ & & $\mathrm{TBD}^{\mathrm{d}}$ & $\mathrm{TBD}^{\mathrm{d}}$ & $\mathrm{TBD}^{\mathrm{d}}$ & $\mathrm{TBD}^{\mathrm{d}}$ & $\mathrm{TBD}^{\mathrm{d}}$ & $\mathrm{TBD}^{\mathrm{d}}$ & $\mathrm{TBD}^{\mathrm{d}}$ & $\mathrm{TBD}^{\mathrm{d}}$ \\
\hline $\begin{array}{l}\text { Wooden } \\
\text { Shed }\end{array}$ & $\mathrm{TBD}^{\mathrm{d}}$ & $\mathrm{TBD}^{\mathrm{d}}$ & $\mathrm{TBD}^{\mathrm{d}}$ & $\mathrm{TBD}^{\mathrm{d}}$ & & $\mathrm{TBD}^{\mathrm{d}}$ & $\mathrm{TBD}^{\mathrm{d}}$ & $\mathrm{TBD}^{\mathrm{d}}$ & $\mathrm{TBD}^{\mathrm{d}}$ & $\mathrm{TBD}^{\mathrm{d}}$ & $\mathrm{TBD}^{\mathrm{d}}$ & $\mathrm{TBD}^{\mathrm{d}}$ & $\mathrm{TBD}^{\mathrm{d}}$ \\
\hline
\end{tabular}

${ }^{\text {aBuilding }} 5400$ includes the overpressure well, access tunnel, reactor room east and west of the lead wall, basement, sump, and surrounding soil. ${ }^{b}$ Building 5400A includes samples taken on the interior and exterior of Building 5400A.

'Unless otherwise noted.

${ }^{\mathrm{d}}$ Suggested sample types include building media, direct surveys, and swipes to be collected during the decontamination and decommissioning activities.

Co $=$ Cobalt

Cs $=$ Cesium

$\mathrm{Eu}=$ Europium

$\mathrm{Fe}=$ Iron

$\mathrm{MDL}=$ Minimum detectable level

\author{
$\mathrm{Ni}=$ Nickel \\ $\mathrm{pCi} / \mathrm{g}=$ Picocuries per gram \\ $\mathrm{pCi} / \mathrm{L}=$ Picocuries per liter \\ $\mathrm{Sr}=$ Strontium \\ TBD $=$ To be determined \\ $\mathrm{U}=$ Uranium
}

$\mathrm{Pu}=$ Plutonium

\section{Uncontrolled When Printed}


Table 2-2

Maximum Chemical Concentrations for Source Material at CAU 118

\begin{tabular}{|c|c|c|c|c|c|c|c|c|c|c|c|}
\hline Location & $\begin{array}{l}\text { Sample } \\
\text { Media }\end{array}$ & Arsenic & Barium & Cadmium & Chromium & Lead & Mercury & Selenium & Silver & $\begin{array}{c}\text { Aroclor- } \\
1248\end{array}$ & $\begin{array}{c}\text { Aroclor- } \\
1254\end{array}$ \\
\hline \multirow{5}{*}{$\begin{array}{c}\text { Building } \\
5400^{\mathrm{a}}\end{array}$} & Liquid (mg/L) & 0.036 & 0.77 & 0.003 & 2.1 & 0.12 & $3.8 \times 10^{-5}$ & $\overline{<\mathrm{MDL}}$ & 0.25 & 0.081 & $\overline{<M D L}$ \\
\hline & $\begin{array}{c}\text { Crane/ } \\
\text { Robotic Arm } \\
\text { Oil }(\mathrm{mg} / \mathrm{kg})\end{array}$ & $<M D L$ & 470 & 0.27 & 0.19 & 33 & 0.0033 & 4.3 & $<M D L$ & 1.9 & $<M D L$ \\
\hline & $\begin{array}{l}\text { Basement } \\
\text { Sump/Tank } \\
\text { Oil (mg/kg) }\end{array}$ & $<M D L$ & $<M D L$ & $<\mathrm{MDL}$ & 0.19 & 0.22 & 0.0064 & 0.55 & $<M D L$ & 43,000 & $<\mathrm{MDL}$ \\
\hline & $\begin{array}{l}\text { Paint chips } \\
\text { (mg/kg) }\end{array}$ & 6.8 & 4,100 & 5.9 & 1,500 & 1,300 & 0.68 & $<\mathrm{MDL}$ & 0.78 & 14,000 & 14,000 \\
\hline & $\begin{array}{c}\text { Surface } \\
\text { Swipe } \\
\text { ( } \mu \mathrm{g} / \text { sample) }\end{array}$ & 1.3 & 210 & 7 & 3.7 & 98 & 0.38 & 0.75 & 0.81 & 6,300 & 32 \\
\hline $\begin{array}{l}\text { Building } \\
5400 \mathrm{~A}^{\mathrm{b}}\end{array}$ & Filter (mg/kg) & 3.7 & 530 & 9 & 13 & 130 & 0.32 & 0.89 & 0.58 & $<M D L$ & $<M D L$ \\
\hline $\begin{array}{l}\text { Building } \\
5410\end{array}$ & $\mathrm{TBD}^{\mathrm{c}}$ & $\mathrm{TBD}^{\mathrm{c}}$ & $\mathrm{TBD}^{\mathrm{c}}$ & $\mathrm{TBD}^{\mathrm{c}}$ & $\mathrm{TBD}^{\mathrm{c}}$ & $\mathrm{TBD}^{\mathrm{c}}$ & $\mathrm{TBD}^{\mathrm{c}}$ & $\mathrm{TBD}^{\mathrm{c}}$ & $\mathrm{TBD}^{\mathrm{c}}$ & $\mathrm{TBD}^{\mathrm{c}}$ & $\mathrm{TBD}^{\mathrm{c}}$ \\
\hline $\begin{array}{l}\text { Wooden } \\
\text { Shed }\end{array}$ & $\mathrm{TBD}^{\mathrm{c}}$ & $\mathrm{TBD}^{\mathrm{c}}$ & $\mathrm{TBD}^{\mathrm{c}}$ & $\mathrm{TBD}^{\mathrm{c}}$ & $\mathrm{TBD}^{\mathrm{c}}$ & $\mathrm{TBD}^{\mathrm{c}}$ & $\mathrm{TBD}^{\mathrm{c}}$ & $\mathrm{TBD}^{\mathrm{c}}$ & $\mathrm{TBD}^{\mathrm{c}}$ & $\mathrm{TBD}^{\mathrm{c}}$ & $\mathrm{TBD}^{\mathrm{c}}$ \\
\hline
\end{tabular}

${ }^{\text {aBuilding }} 5400$ includes the overpressure well, access tunnel, reactor room east and west of the lead wall, basement, sump, and surrounding soil.

${ }^{\mathrm{b} B u i l d i n g} 5400 \mathrm{~A}$ includes samples taken on the interior and exterior of Building 5400A

'Suggested sample types include building media, direct surveys, and swipes to be collected during decontamination and decommissioning activities.

MDL = Minimum detectable limit $\mathrm{mg} / \mathrm{kg}=$ Milligrams per kilogram

$\mathrm{mg} / \mathrm{L}=$ Milligrams per liter

$\mathrm{TBD}=$ To be determined

$\mu \mathrm{g} / \mathrm{kg}=$ Micrograms per kilogram 
reinforced concrete and is approximately 24 inches (in.) thick and 930 square feet $\left(\mathrm{ft}^{2}\right)$ in area. The High Bay contains an overhead crane, HVAC and stack, and HEPA filter and stack. A rolling metal door and two personnel doors provide access to the building (NPS, 2000). The building was designed to withstand positive pressure, has no floor drains (Norman Engineering, 1964b and 1968), and is considered self-contained.

\subsubsection{History and Process Knowledge}

Building 5400A was added to the existing Reactor Building (Building 5400) in 1968, roughly four years after the reactor was constructed and began operation (NPS, 2000). During the period of reactor operation, samples destined for tests in the reactor could be stored in the High Bay (LRL, 1969). On occasion, plutonium was also handled in this area (Kelly, 2000). Between the years of 1969 and 1971, tritium and trace amounts of chlorine (Cl)-38 were released through the vent stack (Miller, 1972). The tritium may present a concern for the High Bay and surrounding soil and vegetation, though due to its short half life, the Cl-38 is not a likely contaminant of concern. Due to the nature of tritium, it is also unlikely that any detectable amounts remain in the surrounding soils.

The High Bay was decontaminated following decontamination and decommissioning (D\&D) of the reactor in 1979. At that time, no removable alpha or beta/gamma contamination was detected on the floors or walls. Equipment and parts were cleaned or wrapped in plastic with no contamination detected on the surface of the plastic (Peterson, 1979). Information from interviews indicate that a radiographic unit and depleted uranium used for shielding may be stored in the High Bay (Roy, 1994). Cobalt (Co)-60 was used to calibrate the radiographic unit. Unknown materials from a project unrelated to Super Kukla were also stored in the High Bay as of 1993 (DOE/NV, 1993b). Any contamination found on the exterior of Building 5400A is suspected to be from airborne releases from facilities outside of the Super Kukla Facility.

\subsubsection{Available Global Information}

Site Confirmation: Various media were sampled during the Site Confirmation in early 2006 to assess the extent of contamination and contaminants present in building media in Building 5400A. Radiological surveys were performed to assess fixed and removable radioactive contamination for both the High Bay interior and exterior surfaces. Metal and oil samples were collected from the 
interior. Building media, HEPA filters, HVAC insulation and filters, and potential ACM media were sampled from the exterior.

Information regarding the specific radiological and chemical contaminants found on the interior and exterior of Building 5400A during the Site Confirmation are presented in Tables 2-1 and 2-2 and in Table 3-3. Identified radiological contaminants from Building 5400A samples include Co-60, cesium (Cs)-137, plutonium (Pu)-239, strontium (Sr)-90, (uranium) U-234, U-235, and U-238. Traces of arsenic, barium, cadmium, chromium, lead, mercury, selenium, and silver (Resource Conservation and Recovery Act [RCRA] metals) were found on filter media. A lead sheet attached to a plywood board was found in Building 5400A during the Site Confirmation. Samples of suspected ACM taken from HVAC insulation on the exterior of the building and insulation panels inside 5400A were found not to contain asbestos. It is assumed that a desktop found in 5400A contains non-friable asbestos (SNJV, 2006). Freon was identified in the HVAC system and a refrigerant system located in Building 5400A and was evacuated from these systems in April 2006.

\subsubsection{Building 5400, Reactor Building}

Located directly beneath the High Bay, Building 5400 formerly housed a prompt burst neutron reactor. The structure is composed of reinforced concrete, with 14-in.-thick walls, a 24-in.-thick ceiling, and a floor slab 36 in. thick at its widest point. The containment room is additionally covered with an earthen mound, a minimum of four feet deep. A curved access tunnel from the ground surface to the containment room is located beyond 4.5-in.-thick blast doors at the west end of the containment room. A stairwell west of the reactor leads to a 12-ft-diameter basement containing a 3-ft-diameter sump located at the base of the reactor stand. The entire Reactor Building footprint extends beyond that of the High Bay and is approximately 1,900 $\mathrm{ft}^{2}$ in area (NPS, 2000).

The containment section of Building 5400 houses a robotic manipulation arm, a 5-ton crane, and a 79,000-pound (lb) partial-height (10-ft-high) lead shielding wall comprised of lead bricks encased in steel. The shielding wall divides the reactor room from east to west and contains a non-hazardous (based on review of the Material Safety Data Sheet [MSDS]) oil-filled viewing window. The reactor fuel and other special nuclear materials were removed in 1979 during site D\&D (Peterson, 1979), though the reactor stand and housing remains in place. 
Building 5400 is self-contained in that there are no open drains leading away from the reactor building (Norman Engineering, 1964a). However, the Reactor Building is connected to the Mechanical Building by underground ventilation ducts and two 1-in. steel pipes associated with the reactor's hydraulic system. A 100-ft-deep well is located adjacent to the building's east wall for emergency overpressure venting (Kelly, 2000). A visual inspection of the overpressure well, surveys performed inside the gasket, and additional interviews with a former reactor engineer on the history of operations (Strand, 2005), provide no evidence that the overpressure seal was ever breached. As such, no contamination into the well or surrounding soil is believed to have occurred.

In the time since the 1979 D\&D activities, oil suspected to contain PCBs had leaked from the overhead crane onto the floor. The basement contains numerous small spills of PCB-containing hydraulic oil (Pydraul) and other contaminated building components and debris (DOE/NV, 1996). In the access tunnel, wiring has deteriorated, and there is visible evidence of water damage to painted surfaces. The access tunnel also contains round metal canisters and other miscellaneous debris associated with testing.

\subsubsection{History and Process Knowledge}

The reactor was built in 1964, and it operated from 1964 until 1979 to test the effects of "prompt bursts" (intense pulses of radiation) on samples of fissile and other materials. In 1979, tests at the reactor were halted and the reactor core was disassembled (Peterson, 1979). The containment room, basement, and access tunnel were included in the 1979 D\&D activities (Peterson, 1979). During the period of reactor operation, samples destined for tests in the reactor could be stored in the Reactor Building (LRL, 1969). On occasion, plutonium was also handled in this area (Kelly, 2000). Depleted uranium and neutron sources previously stored in Building 5400 have been removed (DOE/NV, 1993b).

Much of the radioactive contamination in Building 5400 is due to activation of building materials (e.g., steel, concrete) that occurred during reactor operation. Other materials irradiated from the reactor include test canisters, tools, and equipment now stored in the access tunnel. In 1971, a shim rod drive failed, resulting in a small addition of removable contamination around the reactor stand (east of the lead wall) in the containment room (LRL, 1971). This area is currently posted as a 
contamination area. The containment room was also coated with gadolinium paint, a non-toxic metal used as a neutron absorber to protect equipment during reactor bursts (Kelly, 2000).

\subsubsection{Available Global Information}

Building 5400 contains activated debris and structural materials from reactor activities. Radiological surveys performed after D\&D activities in 1979 showed that removable alpha and beta/gamma contamination levels in the containment room, basement, and access tunnel were less than 100 disintegrations per minute per 100 square centimeters $\left(\mathrm{dpm} / 100 \mathrm{~cm}^{2}\right)(\mathrm{DOE} / \mathrm{NV}, 1993 \mathrm{~b})$. Trace amounts of depleted uranium were found in the containment room. The source of the uranium is reactor core rings, control rods, and shimming disks (LLNL, 1973).

Site Confirmation: Radiological surveys and media samples were taken from Building 5400 during the site confirmation phase in early 2006. Surveys were taken to assess fixed and removable radioactive contamination for the overpressure well, access tunnel, reactor room (both east and west of the lead wall and in ventilation ducts), basement, and sump. Concrete, paint, HVAC, and HEPA media samples were collected from the access tunnel. Paint, concrete, and crane oil samples were taken from the reactor room, west of the lead wall. Paint and concrete samples were taken from the reactor room, east of the lead wall. Paint, concrete and PCB oil samples were taken from the basement. Surface soil samples were taken in the area surrounding Building 5400 to characterize the extent of soil activation that took place during reactor operation.

Hydraulic oil samples were collected from the basement sump and reservoir tank and analyzed. This oil was subsequently drained from the hydraulic system, reservoir tank, and sump in May 2006, and the system was triple-rinsed and flushed with diesel in accordance with Toxic Substances Control Act (TSCA) regulations (CFR, 2003c). The drained oil and diesel used in the rinse were subsequently sampled and are pending results for disposal. Oils from the overhead crane and robotic arm were also drained and sampled.

Information regarding the specific radiological and chemical contaminants found in the containment room, basement, and access tunnel of Building 5400 during the Site Confirmation are presented in Tables 2-1 and 2-2, and in Table 3-3. Identified radiological contaminants from Building 5400 samples include Co-60, Cs-137, europium (Eu)-152, Eu-155, iron (Fe)-55, tritium, nickel (Ni)-63, 
Pu-239, Sr-90, U-234, U-235, and U-238. Polychlorinated biphenyls were found in paint, oils, surface swipe, and surrounding soil. Lead was found in swipes from the overpressure line and reactor room wall, paint chips, and surface soil. Mercury was identified in paint chip samples from the access tunnel and reactor room, and in swipes, oils, and surrounding soils. It is assumed that a fire blanket placed in a cabinet of the access tunnel contains asbestos. Freon was identified in one refrigerant system located in the reactor room, and was evacuated from the system in April 2006. Other contaminants include arsenic, barium, cadmium, chromium, selenium, and silver (RCRA metals) found in various media. All activity results for surface soil samples collected around Building 5400 are less than the corresponding preliminary action levels (PALs) for gamma-spectroscopy isotopes (see Table 3-6). Analytical results indicate that COPCs present in the soil would not pose a safety risk to site personnel during closure activities.

The waste inventory performed during Site Confirmation confirmed that Building 5400 contains a number of pieces of small equipment, supplies, cabinets, tools, tool boxes, electronic components containing lead and mercury, packaged waste, incandescent light bulbs, ACM, emergency lighting equipment, phones, speakers, motion detectors, cameras, testing equipment, and equipment leftover from reactor operation and demolition, characterization, and cleanup activities conducted in 1979.

\subsubsection{Building 5410, Mechanical Building}

The Mechanical Building is a one-room prefabricated metal building with a rigid frame located southwest of the Reactor Building and High Bay. The floor area is approximately $912 \mathrm{ft}^{2}$, and the building is at ground level on a concrete slab (Norman Engineering, 1964c). Building 5410 is considered self-contained in that there are no drains leading away from the building (Norman Engineering, 1964c). However, it is connected to Building 5400 via air ducts for an underground ventilation system and hydraulic piping (Norman Engineering, 1964d). At least one posted contaminated area exists inside.

\subsubsection{History and Process Knowledge}

During the period of reactor operation, the Mechanical Building housed power control and distribution equipment, the hydraulic power unit, and HVAC for the containment building. These systems included compressed nitrogen containers, an air compressor, an 80-gallon hydraulic tank that 
operated the lower half of the reactor, pumps for the hydraulic system, a Pydraul reservoir, insulated piping, air filters, aluminum trash cans, impeller blades and motors, lubricating oils, and methanol (IT, 1996). In 1970, a Pydraul spill occurred when an O-ring seal failed (Garcia, 2000). According to the Decontamination and Decommissioning Program Building Decommissioning Data Sheets, the Mechanical Building was decontaminated in 1979 along with other buildings at the Super Kukla Facility, though no radiological surveys have yet been performed to determine the current extent of contamination (DOE/NV, 1993b).

\subsubsection{Available Global Information}

Site Confirmation: The mechanical building was not part of the original scope for CAS 27-41-01, so radiological surveys and media samples were not taken during the Site Confirmation phase. Evidence of PCB-containing hydraulic oil (Pydraul) on the floor from a previous oil spill is evident on the exterior of the building by a visible stain on the concrete slab. The building may also contain radioactive sources and removable contamination in the ventilation system ducts and filters. Additional characterization data and surveys will be required during the SAFER activities to further assess the current nature and extent of contaminants within Building 5410. Methanol may be a COPC in Building 5410, based on information found in historical documentation on CAU 118 (IT, 1996).

\subsubsection{Wooden Shed}

The Wooden Shed is a two-story structure on skids located west of the Mechanical Building. The floor area is approximately $460 \mathrm{ft}^{2}$. The Wooden Shed is considered self-contained in that there are no drains leading away from the building; however, there may be potential issues regarding the shed's structural integrity. The shed is currently being used to store radiation-impacted materials and equipment (mostly solid media, but there is a potential for liquids in one drum), and is posted as a radioactive materials controlled area.

\subsubsection{History and Process Knowledge}

It is believed that the Wooden Shed was used to house the activated steel and potentially other debris associated with reactor test samples (Kelly, 2000). No decontamination activities took place at the Wooden Shed during the 1979 D\&D. 


\subsubsection{Available Global Information}

Site Confirmation: Media samples were not collected from the Wooden Shed during the Site Confirmation. Samples to characterize the shed's structure and contents will be collected for waste management purposes and to confirm the planned closure strategy. Screening surveys performed in late 2005 inside the shed indicated background levels of radioactivity. Any contamination on the exterior of the shed is expected to be from airborne releases from facilities outside of the Super Kukla Facility (SNJV, 2006). Due to the fact that the shed is constructed of wood and is porous, it is expected to be disposed of as LLW according to Nevada Test Site Waste Acceptance Criteria (NTSWAC) requirements (NNSA/NSO, 2005).

A waste inventory performed for the Wooden Shed during Site Confirmation revealed a number of testing and container assembly parts, including test canisters, drums (some possibly containing liquids), boxed control rods, and other components. Most of the equipment in the shed was used for the reactor project, though some material is new (in the box) and will be managed as if it is activated material (LLW). Once structural integrity of the second floor has been demonstrated, sample canister parts on the second floor of the shed will be characterized for radiological and/or RCRA regulated concerns, as appropriate. Due to its physical nature and the association of debris from the Wooden Shed with reactor operations, most of this material is expected to be placed in Building 5400 for entombment. 


\subsection{Data Quality Objectives}

The DQO process is a seven-step strategic planning method based on the scientific method that was used to plan data collection activities and define performance criteria for the CAU 118, Area 27 Super Kukla Facility field investigation. The DQOs are designed to ensure that the data collected will provide sufficient and reliable information to determine the appropriate corrective actions, verify the adequacy of existing information, provide sufficient data to implement the corrective actions, and verify that closure was achieved.

The seven steps of the DQO process presented in Section 3.1.1 through 3.1.7 were developed in accordance with the U.S. Environmental Protection Agency (EPA) Guidance for the Data Quality Objectives Process (EPA, 2000b) and EPA Guidance for Quality Assurance Project Plans (EPA, 2002). The DQO process presented herein is based on the EPA Quality System Document for DQOs entitled Data Quality Objectives Process for Hazardous Waste Site Investigations, (EPA, 2000a) and the CAS-specific information presented in Section 3.1.1.

In general, the procedures used in the DQO process provide:

- A scientific basis for making inferences about a site (or portion of a site) based on environmental data or process knowledge.

- A basis for defining decision performance criteria and assessing the achieved decision quality of the data collection design.

- Criteria for knowing when site investigators should stop data collection and to verify the closure decision (i.e., when sufficient information is available to support decisions).

- A basis for demonstrating an acceptable level of confidence in the sampling approach to generate the appropriate quantity and quality of information necessary to minimize the potential for making decision errors.

\subsection{Summary of DQO Analysis}

The presence of many contaminants within building media and associated debris of the CAS have already been verified through process knowledge, historical data, and the samples collected as part of the Site Confirmation. The data from the Site Confirmation will be used for waste management 
determinations and to support the selection of closure in place as the corrective action recommended in this SAFER document. Therefore, this DQO section primarily addresses the data needs to determine whether activation/contamination remains in the surrounding soil. The data from the facility's adjacent soils will be used to determine the nature and extent of potential activation and contamination in the environment, if present, in accordance with the DQO process detailed in this section.

\subsubsection{Step 1 - State the Problem}

The problem statement for the CAU 118 CAS is: “Additional information is required to determine the existence of contamination and/or to characterize waste and verify the closure decision for CAS 27-41-01, CAU 118.” This information must be verified and presented in order to close CAU 118 under the SAFER process.

There currently exists sufficient data and process knowledge to identify the nature and extent of several known contaminants (e.g., lead in paint, PCBs in hydraulic oil, activation products in concrete and steel). The additional information specified in the problem statement is expected to be obtained through minimal, in-process sampling (i.e., soils) and survey collection to be performed during the closure actions.

\subsubsection{Planning Team Members}

The DQO planning team consists of representatives from NDEP, NNSA/NSO, SNJV, and the management and operating (M\&O) contractor. The primary decision-makers are the NDEP and NNSA/NSO representatives. Table 3-1 lists the affiliations of the planning team members and representatives from each organization in attendance at the May 26, 2006, DQO meeting.

\subsubsection{Conceptual Site Model}

The CSM is used to organize and communicate information about site characteristics. It reflects the best interpretation of available information at any point in time. The CSM is a primary vehicle for communicating assumptions about release mechanisms, potential migration pathways, or specific constraints. It provides a summary of how and where contaminants are expected to move and what impacts such movement may have. It is the basis for assessing how contaminants could reach 
Table 3-1

Planning Team Members for CAU 118

May 26, 2006

\begin{tabular}{|c|c|}
\hline Participant & Affiliation \\
\hline \hline${ }^{*}$ Task Manager & Nevada Division of Environmental Protection \\
\hline${ }^{*}$ Task Manager & National Nuclear Security Administration Nevada Site Office \\
\hline${ }^{*}$ Technical Lead & Stoller-Navarro Joint Venture \\
\hline${ }^{*}$ Program Manager, Industrial Sites & Stoller-Navarro Joint Venture \\
\hline${ }^{*}$ EC/WM Lead & Stoller-Navarro Joint Venture \\
\hline *RadCon Lead & Stoller-Navarro Joint Venture \\
\hline RadCon Manager & Stoller-Navarro Joint Venture \\
\hline QA Lead & Stoller-Navarro Joint Venture \\
\hline *Technical Lead & Bechtel Nevada \\
\hline Task Manager & Bechtel Nevada \\
\hline *Program Manager & Bechtel Nevada \\
\hline Analytical Services Lead & Stoller-Navarro Joint Venture \\
\hline *Task Manager & Stoller-Navarro Joint Venture \\
\hline${ }^{*}$ Sealth and Safety Manager & Stoller-Navarro Joint Venture \\
\hline
\end{tabular}

*Present at the May 26, 2006, DQO Meeting.

$\mathrm{EC}=$ Environmental Compliance

RadCon $=$ Radiological Control

$\mathrm{QA}=$ Quality Assurance

$\mathrm{WM}=$ Waste Management

receptors both in the present and future. The CSM describes the most probable scenario for current conditions at each site and defines the assumptions that are the basis for identifying appropriate sampling strategy and data collection methods. Accurate CSMs are important as they serve as the basis for all subsequent inputs and decisions throughout the DQO process.

The CSM was developed for CAU 118 using information from the physical setting, potential contaminant sources, release information, historical background information, knowledge from similar sites, personnel interviews, analytical results, and physical and chemical properties of the potentially affected media and COPCs.

The CSM consists of:

- Potential contaminant releases, including media subsequently affected. 
- Release mechanisms (the conditions associated with the release).

- Potential contaminant source characteristics, including contaminants suspected to be present and contaminant-specific properties.

- Site characteristics, including physical, topographical, and meteorological information.

- Migration pathways and transport mechanisms that describe the potential for migration and where the contamination may be transported.

- The locations of points of exposure where individuals or populations may come in contact with a COC associated with the CAS.

- Routes of exposure where contaminants may enter the receptor.

Corrective Action Unit 118 consists of four structures that contain debris and contaminated materials. The debris includes stored equipment, materials, and liquids (e.g., oil, Freon) left over from operation of the Super Kukla prompt burst reactor.

Figure 3-1 represents site conditions applicable to the CSM. This diagram shows suspected locations of contaminants and potential pathways for physical transport. The CSM contains all applicable contaminated facilities, including hazardous and radioactively impacted materials from reactor operation. The applicability of the CSM to the CAS is summarized in Table 3-2 and discussed below. Table 3-2 provides information on CSM elements that will be used throughout the remaining steps of the DQO process.

If additional elements are identified during the investigation that are outside the scope of the CSM, the situation will be reviewed and a recommendation will be made as to how to proceed. In such cases, NDEP and NNSA/NSO will be notified and given the opportunity to comment on and concur with the recommendation. 


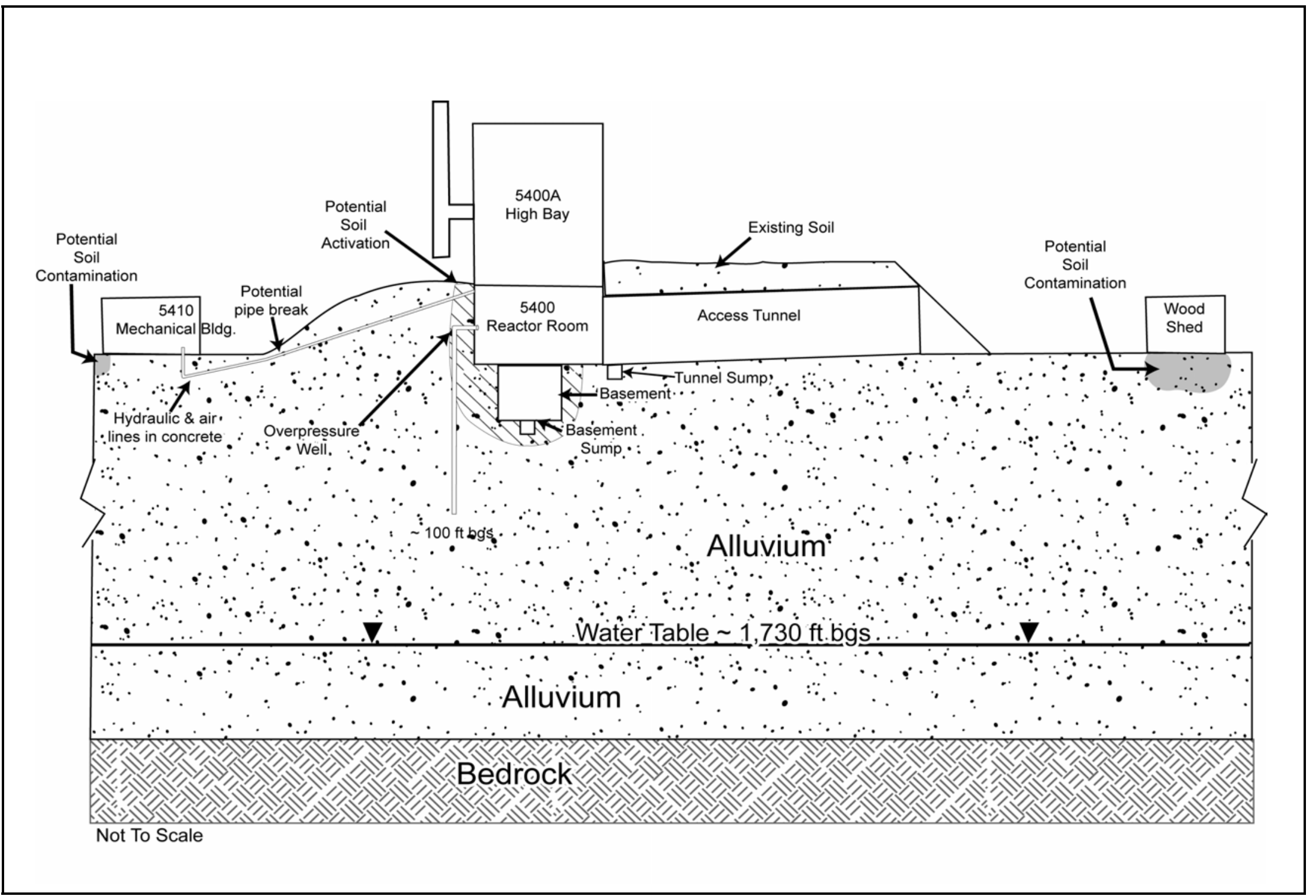

Figure 3-1

Conceptual Site Model for CAS 27-41-01, CAU 118 
Table 3-2

Conceptual Site Model

Description of Elements CAS 27-41-01, CAU 118

\begin{tabular}{|c|c|}
\hline CAS Identifier & 27-41-01 \\
\hline CAS Description & Super Kukla Reactor Building/High Bay \\
\hline Site Status & Site is abandoned and partially disassembled. \\
\hline Exposure Scenario & Occasional Use \\
\hline $\begin{array}{l}\text { Sources of Potential } \\
\text { Contamination }\end{array}$ & $\begin{array}{l}\text { Neutron activation products from Buildings } 5400,5400 A \text {, and } 5410 \text {; chemical contaminants } \\
\text { from Buildings } 5400,5410 \text {, and the Wooden Shed. }\end{array}$ \\
\hline $\begin{array}{l}\text { Location of } \\
\text { Contamination/ } \\
\text { Release Point }\end{array}$ & $\begin{array}{l}\text { Buildings 5400, 5400A, and } 5410 \text { media, structure, and contents (e.g., oils in hydraulic } \\
\text { system, overhead cranes, sump); debris stored in the Wooden Shed. }\end{array}$ \\
\hline Amount Released & Unknown \\
\hline Affected Media & Sump, piping, building structure and media, surface and/or shallow subsurface soil. \\
\hline Potential Contaminants & See Table 3-3. \\
\hline Transport Mechanisms & $\begin{array}{l}\text { Infiltration and percolation of precipitation is the primary driving force for downward } \\
\text { migration of contaminants that may have reached the soil. }\end{array}$ \\
\hline Migration Pathways & $\begin{array}{l}\text { For contaminants that may have reached the soil, vertical transport is expected to } \\
\text { dominate over lateral transport due to small surface gradients. The final closure strategy } \\
\text { assumes that the potential for migration of contaminants from Building } 5400 \text { has been } \\
\text { eliminated. }\end{array}$ \\
\hline $\begin{array}{l}\text { Lateral and Vertical } \\
\text { Extent of } \\
\text { Contamination }\end{array}$ & $\begin{array}{l}\text { Contamination, if present, is expected to be contiguous to the release points. } \\
\text { Concentrations are expected to decrease with distance and depth from the source. } \\
\text { Groundwater contamination is not expected. Lateral and vertical extent of COC } \\
\text { contamination is assumed to be within the spatial boundaries of CAU } 118 .\end{array}$ \\
\hline Exposure Pathways & $\begin{array}{l}\text { The potential for contamination exposure is limited to industrial and construction workers. } \\
\text { These human receptors may be exposed to COPCs through oral ingestion, inhalation, } \\
\text { dermal contact (absorption) of soil and/or debris due to inadvertent disturbance of these } \\
\text { materials, or irradiation by radioactive materials. }\end{array}$ \\
\hline
\end{tabular}

$\mathrm{COC}=$ Contaminant of concern

COPC $=$ Contaminant of potential concern

$\mathrm{PCB}=$ Polychlorinated biphenyl

\subsection{Contaminant Release}

Two potential release scenarios have been identified within CAS 27-41-01: (1) surface or near surface point release of contaminants beneath the Wooden Shed, Building 5400, or Building 5410; or (2) surface and subsurface activation of soils surrounding Building 5400 and the attached access tunnel. Affected or suspected affected media within the CAS include surface and shallow subsurface soils, the Building 5400 sump, piping for the reactor's hydraulic system, and building structure 
material (i.e., activated steel, aluminum, and concrete). Sources for potential releases include activated soil surrounding Building 5400, contaminants from Building 5410 and the Wooden Shed, and activated debris. The potential volume of release at each location is unknown. Contaminant concentrations in soil are expected to decrease with horizontal and vertical distance from the source.

The primary source for potential radionuclide contamination is suspected to be from neutron activation of soil that occurred during reactor operation. However, data collected during the site confirmation phase showed insignificant amounts of activation radionuclides in surface soils. Pending further characterization data from soil closer to the reactor room wall, it is assumed that activation of soils surrounding Building 5400 is minimal. Existing data and process knowledge of operations (see Section 2.2.2) of the overpressure line bladder also suggests that no radiological contamination entered the soil from the overpressure well. Further radiological assessment is needed at Building 5410 and the Wooden Shed.

The primary potential source of a chemical contaminant release is suspected to be from sump fluids containing PCBs. However, the extensive thickness of concrete beneath the sump and the presence of standing oil within the sump suggest excellent containment. No evidence of a release from the sump or Building 5400 has been identified. A PCB hydraulic oil (Pydraul) spill was documented to have occurred in Building 5410 (Garcia, 2000). Further characterization is needed to determine the extent of potential contamination from the spill.

\subsection{Potential Contaminants}

The COPCs were identified during the planning process through the review of site history, process knowledge, personal interviews, past investigation efforts (where available), inferred activities associated with the CAS, and analytical data from the Site Confirmation phase. The list of COPCs is intended to encompass all of the contaminants that could potentially be present at the CAS. The COPCs from CAS 27-41-01 are defined as the constituents reported from the analytical methods stipulated in Table 3-3. Constituents reported for each analytical method are listed in Table 3-4.

Target analytes for soil are:

- Radionuclides: Tritium, Eu-155

- PCBs 
Table 3-3

CAS 27-41-01, CAU 118 Conceptual Site Model COPCs ${ }^{a}$

\begin{tabular}{|c|c|c|c|c|c|c|c|c|}
\hline Analyses $^{a}$ & 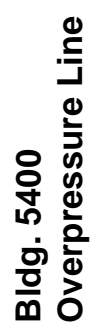 & 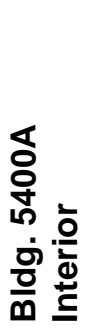 & 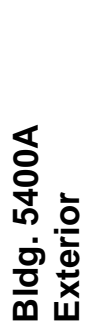 & 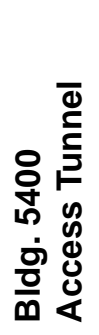 & 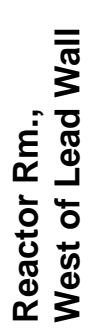 & 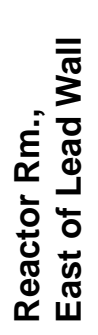 & 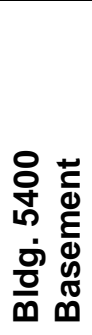 & $\overline{\bar{c}}$ \\
\hline \multicolumn{9}{|c|}{ Organic Contaminants of Potential Concern (COPCs) } \\
\hline Polychlorinated Biphenyls ${ }^{b}$ & $\bar{X}$ & & & $\bar{X}$ & $\bar{X}$ & $\bar{X}$ & $\bar{X}$ & $\bar{x}$ \\
\hline Semivolatile Organic Compounds $^{\mathrm{b}}$ & & & & & & & & $\mathrm{x}$ \\
\hline Volatile Organic Compounds ${ }^{\mathrm{b}}$ & & & & & & & & $\mathrm{x}$ \\
\hline \multicolumn{9}{|c|}{ Inorganic COPCs } \\
\hline $\begin{array}{l}\text { Total Resource Conservation and } \\
\text { Recovery Act Metals }{ }^{c} \text { plus Beryllium }\end{array}$ & $\mathrm{x}$ & & $\mathrm{x}$ & $\mathrm{x}$ & $\mathrm{x}$ & $\mathrm{x}$ & $\mathrm{x}$ & $\mathrm{x}$ \\
\hline \multicolumn{9}{|c|}{ Radionuclide COPCs } \\
\hline Cobalt-60 & & $\bar{X}$ & & & & $\bar{x}$ & & \\
\hline Cesium-137 & & & & & & $x$ & & $\mathrm{x}$ \\
\hline Europium-152 & & & & & $\mathrm{x}$ & $\mathrm{x}$ & & \\
\hline Iron-55 & & & & & & & $\mathrm{x}$ & \\
\hline Tritium & & & & $\mathrm{x}$ & $\mathrm{x}$ & $x$ & $\mathrm{x}$ & \\
\hline Nickel-63 & & & & & & $\mathrm{x}$ & & \\
\hline Plutonium & & & $\mathrm{x}$ & $\mathrm{x}$ & & & & \\
\hline Strontium-90 & & & $x$ & & $\mathrm{x}$ & $\mathrm{X}$ & & \\
\hline Isotopic Uranium ${ }^{\mathrm{b}}$ & $\mathrm{X}$ & $\mathrm{x}$ & $\mathrm{X}$ & $\mathrm{x}$ & $\mathrm{x}$ & $\mathrm{x}$ & $\mathrm{x}$ & $\mathrm{x}$ \\
\hline
\end{tabular}

$X=$ Required analytical method

${ }^{\text {a }}$ SeeTable 2-1 and Table 2-2 for maximum radionuclide activities and chemical concentrations in various source materials. alf the volume of material is limited, prioritization of the analyses will be necessary.

${ }^{\mathrm{b}}$ The contaminants of potential concern are the constituents reported from the analytical methods listed.

${ }^{c}$ Arsenic, Barium, Cadmium, Chromium, Lead, Mercury, Selenium, and Silver.

\subsection{Contaminant Characteristics}

Contaminant characteristics include, but are not limited to: solubility, density, and adsorption potential. In general, contaminants with large particle size, low solubility, high affinity for media, and/or high density can be expected to be found relatively close to release points. Contaminants with 
Table 3-4

Page 30 of 98

Analytes Reported by Analytical Methods

\begin{tabular}{|c|c|c|c|c|c|c|}
\hline \multicolumn{2}{|c|}{ VOC } & svoc & PCB & Metals & Pesticides & Radionuclides \\
\hline $\begin{array}{l}\text { 1,1,1-Trichloroethane } \\
\text { 1,1,1,2-Tetrachloroethane } \\
\text { 1,1,2,2-Tetrachloroethane } \\
\text { 1,1,2--Trichloroethane } \\
\text { 1,1-Dichloroethane } \\
\text { 1,1-Dichloroethene } \\
\text { cis-1,2-Dichloroethene } \\
\text { 1,2-Dichloroethane } \\
\text { 1,2-Dichloropropane } \\
\text { 1,2,4-Trichlorobenzene } \\
\text { 1,2,4-Trimethylbenzene } \\
\text { 1,2-Dibromo-3-chloropropane } \\
\text { 1,3,5-Trimethylbenzene } \\
\text { 1,4-Dioxane } \\
\text { 2-Butanone } \\
\text { 2-Chlorotoluene } \\
\text { 2-Hexanone } \\
\text { 4-Methyl-2-pentanone } \\
\text { Acetone } \\
\text { Acetonitrile } \\
\text { Allyl chloride } \\
\text { Benzene } \\
\text { Bromodichloromethane } \\
\text { Bromoform } \\
\text { Bromomethane } \\
\text { Carbon disulfide } \\
\text { Carbon tetrachloride } \\
\text { Chlorobenzene } \\
\text { Chloroethane } \\
\text { Chloroform } \\
\text { Chloromethane } \\
\text { Chloroprene } \\
\text { Dibromochloromethane } \\
\text { Dichlorodifluoromethane } \\
\text { Ethyl methacrylate } \\
\text { Ethylbenzene } \\
\text { Isobutyl alcohol } \\
\text { Isopropylbenzene } \\
\text { m-Dichlorobenzene (1,3) } \\
\text { Methacrylonitrile } \\
\text { Methyl methacrylate }\end{array}$ & $\begin{array}{l}\text { Methylene chloride } \\
\text { N-Butylbenzene } \\
\text { N-Propylbenzene } \\
\text { o-Dichlorobenzene (1,2) } \\
\text { p-Dichlorobenzene }(1,4) \\
\text { p-isopropyltoluene } \\
\text { sec-Butylbenzene } \\
\text { Styrene } \\
\text { tert-Butylbenzene } \\
\text { Tetrachloroethene } \\
\text { Toluene } \\
\text { Total Xylenes } \\
\text { Trichloroethene } \\
\text { Trichlorofluoromethane } \\
\text { Vinyl acetate } \\
\text { Vinyl chloride }\end{array}$ & $\begin{array}{l}\text { 2,3,4,6-Tetrachlorophenol } \\
\text { 2,4-Dimethylphenol } \\
\text { 2,4-Dinitrotoluene } \\
\text { 2,4,5-T-Tichlorophenol } \\
\text { 2,4,6-Trichlorophenol } \\
\text { 2-Chlorophenol } \\
\text { 2-Methylnaphthalene } \\
\text { 2-Methylphenol } \\
\text { 2-Nitrophenol } \\
\text { 3-Methylphenola } \\
\text { 4-Chloroaniline } \\
\text { 4-Methylphenol } \\
\text { 4-Nitrophenol } \\
\text { Acenaphthene } \\
\text { Acenaphthylene } \\
\text { Aniline } \\
\text { Anthracene } \\
\text { Benzo(a)anthracene } \\
\text { Benzo(a)pyrene } \\
\text { Benzo(b)fluoranthene } \\
\text { Benzo(g,h,i)perylene } \\
\text { Benzo(k)fluoranthene } \\
\text { Benzoic Acid } \\
\text { Benzyl Alcohol } \\
\text { Bis(2-ethylhexyl) phthalate } \\
\text { Butyl benzyl phthalate } \\
\text { Carbazole } \\
\text { Chrysene } \\
\text { Dibenzo(a,h)anthracene } \\
\text { Dibenzofuran } \\
\text { Diethyl Phthalate } \\
\text { Dimethyl Phthalate } \\
\text { Di-n-butyl Phthalate } \\
\text { Di-n-octyl Phthalate } \\
\text { Fluoranthene } \\
\text { Fluorene } \\
\text { Hexachlorobenzene } \\
\text { Hexachlorobutadiene } \\
\text { Hexachloroethane } \\
\text { Indeno(1,2,3-cd)pyrene } \\
\text { Naphthalene } \\
\text { Nitrobenzene } \\
\text { N-Nitroso-di-n-propylamine } \\
\text { Pentachlorophenol } \\
\text { Phenanthrene } \\
\text { Phenol } \\
\text { Pyrene } \\
\text { Pyridine }\end{array}$ & $\begin{array}{l}\text { Aroclor } 1016 \\
\text { Aroclor } 1221 \\
\text { Aroclor } 1232 \\
\text { Aroclor } 1242 \\
\text { Aroclor } 1248 \\
\text { Aroclor } 1254 \\
\text { Aroclor } 1260 \\
\text { Aroclor } 1268\end{array}$ & $\begin{array}{l}\text { Arsenic } \\
\text { Barium } \\
\text { Beryllium } \\
\text { Cadmium } \\
\text { Chromium } \\
\text { Lead } \\
\text { Mercury } \\
\text { Selenium } \\
\text { Silver }\end{array}$ & $\begin{array}{l}\text { 4,4'-DDD } \\
\text { 4,4'-DDE } \\
\text { 4,4'-DDT } \\
\text { Aldrin } \\
\text { Alpha-BHC } \\
\text { Alpha-Chlordane } \\
\text { Beta-BHC } \\
\text { Chlordane (Technical) } \\
\text { Delta-BHC } \\
\text { Dieldrin } \\
\text { Endosulfan I } \\
\text { Endoulfan II } \\
\text { Endosulfan Sulfate } \\
\text { Endrin } \\
\text { Endrin Aldehyde } \\
\text { Edrin Ketone } \\
\text { Gamma-BHC } \\
\text { Gamma-Chlordane } \\
\text { Heptachlor } \\
\text { Heptachlor Epoxide } \\
\text { Methoxychlor } \\
\text { Toxaphene }\end{array}$ & $\begin{array}{l}\text { Carbon-14 } \\
\text { Chlorine-36 } \\
\text { Iron-55 } \\
\text { Nickel-63 } \\
\text { Plutonium-238 } \\
\text { Plutonium-239/240 } \\
\text { Plutonium-241 } \\
\text { Strontium-90 } \\
\text { Uranium-234 } \\
\text { Uranium-235 } \\
\text { Uranium-238 } \\
\text { Other parameters: } \\
\text { Gamma-emitting } \\
\text { radionuclides } \\
\text { including: } \\
\text { Actinium-228 } \\
\text { Aluminum-26 } \\
\text { Americium-241 } \\
\text { Antimony-125 } \\
\text { Beryllium-7 } \\
\text { Bismuth-212 } \\
\text { Bismuth-214 } \\
\text { Cadmium-109 } \\
\text { Cesium-134 } \\
\text { Cesium-137 } \\
\text { Cobalt-57 } \\
\text { Cobalt-58 } \\
\text { Cobalt-60 } \\
\text { Curium-243 } \\
\text { Europium-152 } \\
\text { Europium-154 } \\
\text { Europium-155 } \\
\text { Lead-212 } \\
\text { Lead-214 } \\
\text { Manganese-54 } \\
\text { Niobiumm-94 } \\
\text { Protactinium-234m } \\
\text { Potassium-40 } \\
\text { Thallium-208 } \\
\text { Thorium-227 } \\
\text { Thorium-234 } \\
\text { Uranium-235 } \\
\text { Zinc-65 }\end{array}$ \\
\hline
\end{tabular}


small particle size, high solubility, low affinity for media, and/or low density are found further from release points or in low areas where evaporation of ponding will concentrate dissolved constituents.

\subsection{Site Characteristics}

Site characteristics are the site's physical, topographical, and meteorological attributes and properties. All structures at CAS 27-41-01 are located above a layer of alluvium above bedrock at approximately 4,410 ft elevation (NPS, 2000). The CAS is characterized by an essentially flat topography. Rock formation beneath Area 27 is, in general, an extrusive rock called the Oak Spring formation. Rocks are mostly volcanic in origin and of Tertiary age. The area is characterized by a series of northeast-striking faults, of which the Cane Springs Fault is the longest. Numerous small faults can be found throughout the area (Hannon and McKague, 1975).

Groundwater is not expected to be impacted at the CAS for several reasons. Infiltration of precipitation through subsurface media typically serves as the major driving force for migration of contaminants. Low precipitation and high evapotranspiration rates common at the NTS tend to limit this migration. The average annual precipitation in Area 27 ranges from 3 to 4 in. per year, with flash floods possible from July through September (LRL, 1964). Cement walls that are $14 \mathrm{in}$. thick and a floor that is 36 in. thick at its widest point (NPS, 2000) provide a significant barrier against potential contaminant leakage from Building 5400. In addition, the depth to groundwater at the CAS is approximately 1,730 ft below ground surface (bgs).

\subsection{Migration Pathways and Transport Mechanisms}

The CSM presents the potential migration pathways and transport mechanisms that could move the contaminants vertically and laterally throughout the various media. The pathways include air, surface water, and groundwater, and are the routes through which possible contamination could migrate from the site to locations where a receptor might receive an exposure. Migration and transport are influenced by physical and chemical characteristics of the contaminants and media described in Sections 3.1.1.2.3 and 3.1.1.2.4. Figure 3-2 illustrates the potential migration pathways for COPCs at CAU 118. 
Given the characteristics of the contaminants, reactor containment, alluvium layer, and depth of the water table, contaminant migration through soil is expected to be limited. This is further supported by data collected from surface soils surrounding the reactor facility that indicate no trend of activation of surface soils. Infiltration and percolation of precipitation serves as a driving force for downward migration of contaminants. However, due to high potential evapotranspiration and limited precipitation for this region (3 to 4 in. per year [LRL, 1964]), percolation of infiltrated precipitation at the NTS does not provide a significant mechanism for vertical migration of contaminants to groundwater (DOE/NV, 1992).

Because of the expected limited mobility, the affected media is typically the surface and shallow subsurface soil. The native soil interfaces below and adjacent to the identified release points are the most likely locations for any soil contamination. Any potential contaminants from the CAS, regardless of physical or chemical characteristics, are expected to be in soil adjacent to the identified sources or release points.

Lateral migration of contaminants through impacted soil is expected to be limited because there is a physical barrier between potential contaminants and potentially affected soil, and the CAS resides on a generally flat topography. Lateral migration may occur as a result of overland flow or erosion, and is largely dependent on the integrity of the reactor room barrier. Without a breach in this barrier, lateral migration through the surrounding soil is expected to be insignificant. 


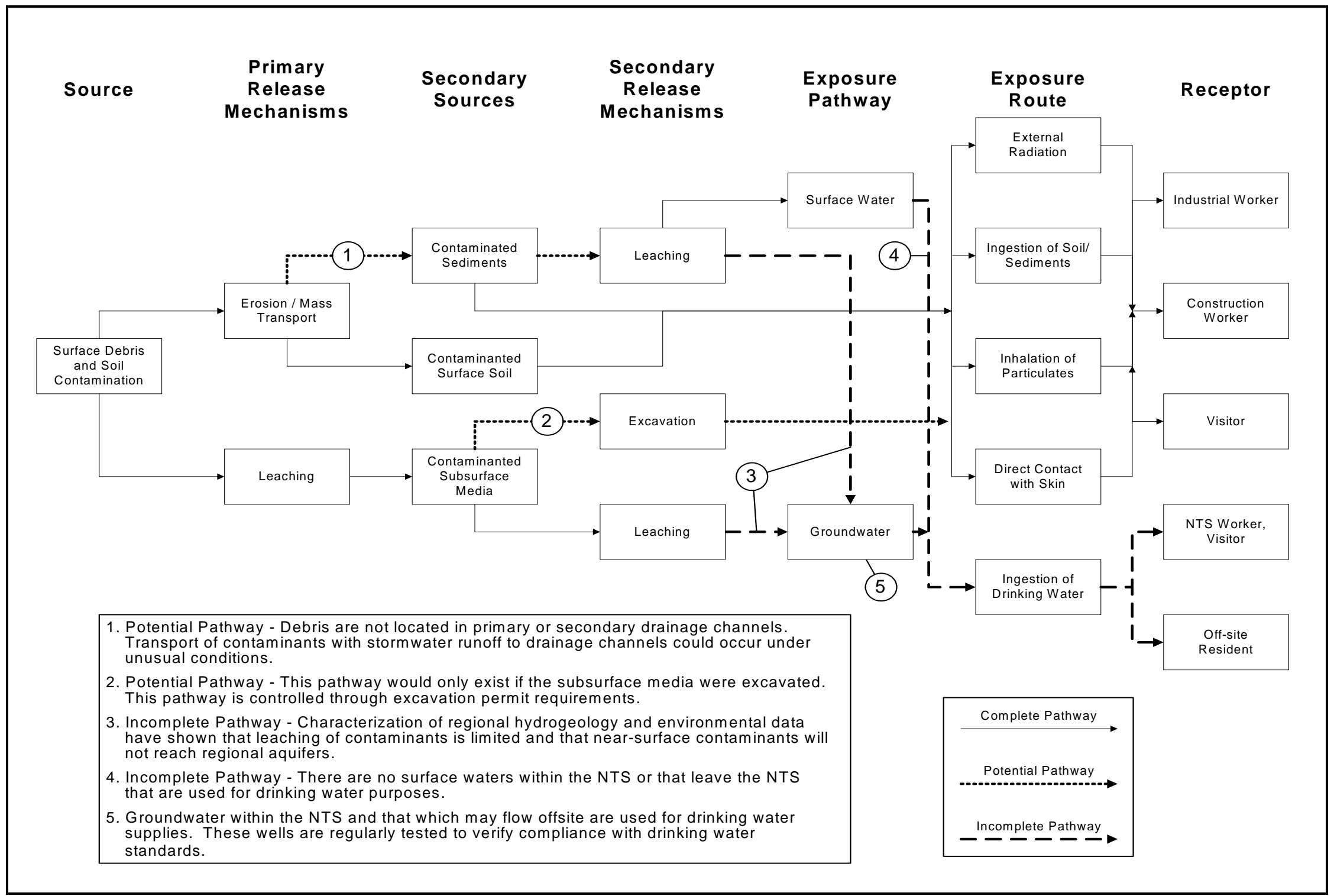

Figure 3-2

Migration Pathways at CAU 118 
Contamination, if present, is expected to be contiguous to the release points, and concentrations are expected to decrease with horizontal and vertical distance from the source. Based on the depth to groundwater, groundwater contamination is not considered a likely scenario. Surface migration may occur as the result of the release or as runoff of precipitation, and is a biasing factor considered in the selection of sampling points.

\subsection{Exposure Scenarios}

Site workers may be exposed to COPCs through oral ingestion, inhalation, dermal contact (absorption) of soil or debris due to inadvertent disturbance of these materials or irradiation by radioactive materials. The exposure of workers and visitors to site contaminants is very dependent upon the activites of the exposed individuals at the site. Based on the Nevada Test Site Resource Management Plan (DOE/NV, 1998), the area in which CAU 118 is located is restricted to use as a nuclear and high explosive test zone.

The appropriate exposure scenario for the CAU 118 CAS is Occasional Use because the site is in a remote area with no active improvements, and the future land use designation is for a nuclear and high explosive test zone. There is still the possibility, however, that site workers could occupy these locations on an occasional and temporary basis. Investigation decisions will be based on the future land-use and exposure scenario for CAU 118 provided in Table 3-5.

Plans for facilities at CAS 27-41-01 include demolition and disposal for Buildings 5400A, 5410 and the Wooden Shed; and filling of the reactor room, basement, sump and access tunnel of Building 5400 with flowable grout. Following closure activities, no facilities will be present for use by NTS site personnel, and Building 5400 will be inaccessible. Because site personnel may periodically perform work at CAU 118, it is considered to be an Occasional Use area.

\subsubsection{Step 2 - Identify Decisions}

Step 2 of the DQO process identifies the decision statements and defines the appropriate actions to be taken based upon the answer to the decision statements. Figure 1-3 depicts the sequential flow of questions, answers, and action alternatives required to fulfill the objectives of the SAFER process. 
Table 3-5

\section{Land-Use and Exposure Scenarios}

\begin{tabular}{||c|l|l|}
\hline CAS & \multicolumn{1}{|c|}{ Record of Decision Land-Use Zone } & \multicolumn{1}{c|}{ Exposure Scenario } \\
\hline \hline 27-41-01 & $\begin{array}{l}\text { Nuclear and High Explosive Test Zone } \\
\text { This area is designated within the Nuclear Test Zone } \\
\text { for additional underground nuclear weapons tests and } \\
\text { outdoor high-explosive tests. This zone includes } \\
\text { compatible defense and nondefense research, } \\
\text { development, and testing activities. }\end{array}$ & $\begin{array}{l}\text { Occasional Use Area } \\
\text { (up to 80 hours per year for 5 years). Site } \\
\text { structures are not present for shelter and } \\
\text { comfort of the worker. }\end{array}$ \\
\hline
\end{tabular}

\subsubsection{Decision Statements}

The Decision I statement is: "Does a COC exist in environmental media, or does potential source material exist that could impact human health or the environment?”

Potential source material has already been verified or is assumed to exist within the CAS buildings and media. This includes PCBs, lead, mercury, and various radionuclides including activiation products. For a judgmental sampling design in surrounding soils, any analytical result for a COPC above the FAL will result in that COPC being designated as a COC. A COC may also be defined as a contaminant that, in combination with other like contaminants, is determined to jointly pose an unacceptable risk based on a multiple constituent analysis (NNSA/NSO, 2006). If a COC is detected, then Decision II must be resolved. It is assumed that building materials and debris that remain in Building 5400 for entombment will not impact human health or the environment because a Use Restriction will be in place and no transport mechanisms exist.

The Decision II statement is: "Is sufficient information available to confirm that closure objectives were met?” Sufficient information is defined to include:

- Identifying the volume of media containing any COC bounded by analytical sample results in lateral and vertical directions.

- The information needed to characterize investigation-derived waste (IDW) for disposal.

- The information needed to determine potential remediation waste types. 
- The information needed to evaluate the feasibility of closure alternatives (evaluation of barriers is considered).

- Identifying actions taken to eliminate exposure pathways.

The evaluation of the need for corrective action will include the potential for wastes that are present to cause the future contamination of site environmental media if the wastes were to be released.

If sufficient information is not available to meet the closure objectives, then site conditions will be re-evaluated and additional samples will be collected (as long as the scope of the investigation is not exceeded and any CSM assumption has not been shown to be incorrect).

\subsubsection{Alternative Actions to the Decisions}

In this section, the actions that may be taken to solve the problem are identified depending on the possible outcomes of the investigation.

If no COCs in adjacent soils of the CAS are detected, then further assessment of the CAS is not required and the corrective action alternative of no further action will be selected. If a COC in soil is detected, then additional sampling will be conducted to determine the extent of COC contamination. If the extent of the contamination is defined and additional remediation is feasible, then the contaminated media will be removed. If the extent of contamination has been determined and additional remediation is not feasible, then the extent of contamination will be defined and the planned Use Restriction will be extended to include the contaminated area.

If the collection of verification samples in soils confirm that all the contaminated media has been removed, then the Use Restriction will include only the building area footprints.

\subsubsection{Step 3 - Identify Inputs to the Decision}

This step identifies the information needed, determines sources for information, and identifies sampling and analysis methods that will allow reliable comparisons of analytical results with FALs. 


\subsubsection{Information Needs}

The following steps will be used to resolve Decision I (determine whether a COC is present):

- Collect samples in areas most likely to contain a COC (judgmental sampling) as determined by site process knowledge (e.g., soil immediately adjacent to the reactor room and underneath the Wooden Shed).

- Assure that the selected analytical suites and minimum detectable levels (MDLs) or minimum detectable concentrations (MDCs) are sufficient to identify any COCs present in the samples.

- Assure collected data are adequate to evaluate the absence of a completed exposure pathway.

To resolve Decision II (determine whether sufficient information is available to confirm that closure objectives were met at the CAS), the following methods will be used:

- Field documentation, including photos, as-built drawings, waste disposal documentation, and final surveys, will be evaluated.

- Additional sampling, as needed, to define the extent of a COC.

- Samples must be collected in areas contiguous to the contamination but where contaminant concentrations are below FALs.

- Samples of the debris or the contaminated environmental media must provide sufficient information to characterize for disposal.

- Samples of the contaminated environmental media must provide sufficient information to determine potential remediation waste types.

- Samples of the native soil beneath the removed contaminated environmental media must provide sufficient information to verify that all contamination has been successfully removed.

- The analytical suites selected must be sufficient to detect contaminants at concentrations equal to or less than their corresponding FALs.

\subsubsection{Sources of Information}

Information to satisfy Decision I and Decision II will be generated by collecting soil samples, metal coupons, concrete cores, paint samples, oil samples, direct surveys and swipes. These samples will be submitted to analytical laboratories meeting the quality criteria stipulated in the Industrial Sites 
Quality Assurance Project Plan (QAPP) (NNSA/NV, 2002a). Only validated data from analytical laboratories will be used to make DQO decisions. Sample collection and handling activities will follow standard procedures.

\subsection{Sample Locations}

Design of the sampling approaches for CAU 118 must ensure that the data collected are sufficient for selection of the corrective action alternatives (EPA, 2002). To meet this objective, the samples collected from the site should be from locations that most likely contain a COC, if present (judgmental). These sample locations, therefore, can be selected by biasing factors used in judgmental sampling (e.g., a stain, likely containing a spilled substance). Because sufficient data were available to develop a judgmental sampling plan, this approach was used to select sample locations for samples taken during site confirmation for CAS 27-41-01. The same approach will be used to select sample locations for samples collected from Building 5410, the Wooden Shed, and additional soil samples surrounding Building 5400. Implementation of the judgmental sampling approach for CAU 118 is discussed below.

Decision I sample locations for samples taken during the site confirmation phase at CAS 27-41-01 were determined based on the likelihood that the sample would contained a COC, if present at the CAS. These locations were selected based on field-screening techniques, biasing factors, the CSM, and existing information. Judgmental sampling techniques will also be used to select sample locations for samples to be taken from Building 5410, the Wooden Shed, and soil surrounding Building 5400. (Analytical suites for Decision I samples include all COPCs identified in Table 3-3).

Field-screening techniques used to select appropriate sampling locations provide quantitative data that can be used to comparatively select samples to be submitted for laboratory analyses from several screening locations. Field screening may also be used for health and safety monitoring and to assist in making certain health and safety decisions. Field-screening was used to select sampling locations during the site confirmation phase, and will be used to select sample locations for further characterization data. The following field-screening methods may be applied at CAU 118:

- Walkover surface area radiological surveys - A radiological survey instrument will be used to detect hot spots of radiological contamination on an as-needed basis (activity dependent). The field-screening levels are determined by RadCon personnel. 
- Alpha and beta/gamma radiation - A radiological survey instrument will be used as needed.

- Gamma emitting radionuclides - A radiological dose rate measurement instrument will be used as needed.

Biasing factors may also be used to select samples to be submitted for laboratory analyses based on existing site information and site conditions discovered during the investigation. The following factors may also be considered in selecting locations for analytical samples at CAU 118:

- Documented process knowledge on source and location of release (e.g., volume of release).

- Stains: Any spot or area on the soil surface that may indicate the presence of a potentially hazardous liquid. Typically, stains indicate an organic liquid such as an oil has reached the soil, and may have spread out vertically and horizontally.

- Elevated radiation: Any location identified during radiological surveys that had alpha/beta/gamma levels significantly higher than surrounding background soil.

- Geophysical anomalies: Any location identified during geophysical surveys that had results indicating surface or subsurface materials existed, and were not consistent with the natural surroundings (e.g., buried concrete or metal, surface metallic objects).

- Drums, containers, equipment or debris: Materials of interest that may have been used at, or added to, a location, and that may have contained or come in contact with hazardous or radioactive substances at some point during their use.

- Preselected areas based on process knowledge of the site: Locations for which evidence such as historical photographs, experience from previous investigations, or interviewee's input, exists indicating that a release of hazardous or radioactive substances may have occurred.

- Preselected areas based on process knowledge of the contaminant(s): Locations that may reasonably have received contamination, selected on the basis of the chemical and/or physical properties of the contaminant(s) in that environmental setting.

- Previous sample results: Locations that may reasonably have been contaminated based upon the results of previous field investigations.

- Experience and data from investigations of similar sites.

- Visual indicators such as discoloration, textural discontinuities, disturbance of native soils, or any other indication of potential contamination.

- Presence of debris, waste, or equipment. 
- Odor.

- $\quad$ Physical and chemical characteristics of contaminants.

- Other biasing factors: Factors not previously defined for the CAI, but become evident once the investigation of the site is under way.

If additional sampling data are needed to satisfy Decision II, Decision II sample locations will be selected based on the CSM, biasing factors, and existing data. Analytical suites will include those parameters that exceeded FALs (i.e., COCs) in prior samples.

\subsection{Analytical Methods}

Analytical methods are available to provide the data needed to resolve the decision statements. The analytical methods and laboratory requirements (e.g., detection limits, precision, and accuracy) for soil and aqueous samples are provided in Tables 3-6 and 3-7.

\subsubsection{Step 4 - Define the Boundaries of the Study}

The purpose of this step is to define the population of interest, define the spatial boundaries, determine practical constraints on data collection, and define the scale of decision making.

\subsubsection{Populations of Interest}

The population of interest to resolve the decisions includes materials that are impacted by a contaminant above the action level.

The population of interest to resolve Decision I ("Does a COC exist in environmental media, or does potential source material exist that could impact human health or the environment?”) is any location within the site that is contaminated with any contaminant above an FAL. The populations of interest to resolve Decision II ("Is sufficient information available to confirm that closure objectives were met?”) are:

- Each one of a set of locations bounding contamination in lateral and vertical directions.

- IDW or environmental media that must be characterized for disposal. 
Table 3-6

Analytical Requirements for Radionuclides for CAU 118

\begin{tabular}{|c|c|c|c|c|c|c|}
\hline $\begin{array}{l}\text { Parameterl } \\
\text { Analyte }\end{array}$ & Matrix & $\begin{array}{l}\text { Analytical } \\
\text { Method }\end{array}$ & MDC $^{a}$ & $P L^{b, c}$ & $\begin{array}{l}\text { Laboratory } \\
\text { Precision } \\
\text { (RPD) }\end{array}$ & $\begin{array}{l}\text { Percent } \\
\text { Recovery } \\
(\% \mathrm{R})\end{array}$ \\
\hline \multicolumn{7}{|c|}{ Gamma Spectroscopy } \\
\hline Cesium-137 & Soil & HASL-300 & $\overline{0.5 \mathrm{pCi} / \mathrm{g}^{\mathrm{e}}}$ & $12.2 \mathrm{pCi} / \mathrm{g}$ & \multirow{3}{*}{$\begin{array}{c}\text { Relative Percent } \\
\text { Difference (RPD) } \\
35 \% \\
\text { Normalized } \\
\text { Difference } \\
-2<\mathrm{ND}<2^{\dagger}\end{array}$} & \multirow{3}{*}{$\begin{array}{c}\text { Laboratory } \\
\text { Control Sample } \\
\text { Recovery } \\
\text { 80-120 } \\
\text { Recovery (\%R) }\end{array}$} \\
\hline Cobalt-60 & Soil & HASL-300 ${ }^{d}$ & $0.5 \mathrm{pCi} / \mathrm{g}^{\mathrm{e}}$ & $2.68 \mathrm{pCi} / \mathrm{g}$ & & \\
\hline Europium-152 & Soil & HASL-300 ${ }^{d}$ & $4 \mathrm{pCi} / \mathrm{g}$ & $5.7 \mathrm{pCi} / \mathrm{g}$ & & \\
\hline \multicolumn{7}{|c|}{ Other Radionuclides } \\
\hline Chlorine-36 & Soil & Lab specific & $100 \mathrm{pCi} / \mathrm{g}$ & & \multirow{9}{*}{$\begin{array}{c}\text { Relative Percent } \\
\text { Difference (RPD) } \\
35 \% \\
\text { Normalized } \\
\text { Difference } \\
-2<N D<2^{f}\end{array}$} & \multirow{9}{*}{$\begin{array}{c}\text { Laboratory } \\
\text { Control Sample } \\
\quad \text { Recovery } \\
80-120^{9} \text { Percent } \\
\text { Recovery (\%R) } \\
\\
\text { Chemical Yield } \\
30-105^{\mathrm{h}} \% \mathrm{R} \\
\text { (not applicable } \\
\text { for tritium) }\end{array}$} \\
\hline Iron-55 & Soil & Lab specific & $20 \mathrm{pCi} / \mathrm{g}$ & & & \\
\hline Tritium & Soil & Lab specific & $400 \mathrm{pCi} / \mathrm{L}^{\mathrm{i}}$ & $\begin{array}{c}4.0 \mathrm{E}+05 \\
\mathrm{pCi} / \mathrm{L}^{\mathrm{i}}\end{array}$ & & \\
\hline Nickel-63 & Soil & Lab specific & $10 \mathrm{pCi} / \mathrm{g}$ & & & \\
\hline Plutonium-239 & Soil & ASTM C1001-00 & $0.05 \mathrm{pCi} / \mathrm{g}$ & $12.7 \mathrm{pCi} / \mathrm{g}$ & & \\
\hline Strontium-90 & Soil & HASL $300^{d}$ & $0.5 \mathrm{pCi} / \mathrm{g}$ & $838 \mathrm{pCi} / \mathrm{g}$ & & \\
\hline Uranium-234 & Soil & ASTM C1000-02 $^{k}$ & $0.05 \mathrm{pCi} / \mathrm{g}$ & $143 \mathrm{pCi} / \mathrm{g}$ & & \\
\hline Uranium-235 & Soil & ASTM C1000-02 $^{k}$ & $0.05 \mathrm{pCi} / \mathrm{g}$ & $17.6 \mathrm{pCi} / \mathrm{g}$ & & \\
\hline Uranium-238 & Soil & ASTM C1000-02 $^{k}$ & $0.05 \mathrm{pCi} / \mathrm{g}$ & $105 \mathrm{pCi} / \mathrm{g}$ & & \\
\hline
\end{tabular}

${ }^{\mathrm{a}}$ The MDC is the lowest concentration of a radionuclide, if present in a sample, that can be detected with a 95 percent confidence level.

${ }^{\mathrm{b}}$ The PALs for soil are based on the National Council for Radiation Protection and Measurement (NCRP) Report No. 129 Recommended Screening Limits for Contaminated Soil and Review of Factors Relevant to Site-Specific Studies (NCRP, 1999) scaled to $25 \mathrm{mrem} / \mathrm{yr}$ dose and the guidelines for residual concentration of radionuclides in DOE Order 5400.5 (DOE, 1993 ).

${ }^{\mathrm{C}} \mathrm{PALs}$ for liquids will be developed as needed.

${ }^{\mathrm{d}}$ The Procedures Manual of the Environmental Measurements Laboratory, HASL-300 (DOE, 1997).

${ }^{\mathrm{e}} \mathrm{MDC}$ s vary depending on the presence of other gamma-emitting radionuclides in the sample and are relative to the MDC for Cesium-137.

${ }^{f} \mathrm{ND}$ is not RPD, it is another measure of precision used to evaluate duplicate analyses. The ND is calculated as the difference between two results divided by the square root of the sum of the squares of their total propagated uncertainties. Evaluation of Radiochemical Data Usability (Paar and Porterfield, 1997).

${ }^{9}$ EPA Contract Laboratory Program Statement of Work for Inorganic Analysis (EPA, 1988, 1994, and 1995).

${ }^{\mathrm{h}}$ General Radiochemistry and Routine Analytical Services Protocol (GRASP) (EG\&G Rocky Flats, 1991). The chemical yield only applies to plutonium, uranium and strontium.

'Units of $\mathrm{pCi} / \mathrm{L}$ will be reported by the analytical laboratory based on the activity of the tritium in the soil moisture. The PAL for tritium in soil is based on the UGTA Project limit of $400,000 \mathrm{pCi} / \mathrm{L}$ for discharge of water containing tritium to an infiltration basin/area (NNSA/NV, 2002b).

${ }^{j}$ Standard Test Method for Radiochemical Determination of Plutonium in Soil by Alpha Spectroscopy (ASTM, 2002).

${ }^{\mathrm{k}}$ Standard Test Method for Radiochemical Determination of Uranium Isotopes in Soil by Alpha Spectrometry (ASTM, 2000).

ASTM = American Society for Testing and Materials

HASL $=$ Health and Safety Laboratory

MDC = Minimum detectable concentration

$\mathrm{mrem} / \mathrm{yr}=$ Millirem per year

$\mathrm{ND}=$ Normalized difference
$\mathrm{PAL}=$ Preliminary action level

$\mathrm{pCi} / \mathrm{g}=$ Picocuries per gram

$\mathrm{pCi} / \mathrm{L}=$ Picocuries per liter

UGTA = Underground Test Area 
Table 3-7

Analytical Requirements for Chemical COPCs for CAU 118

(Page 1 of 2)

\begin{tabular}{|c|c|c|c|c|c|}
\hline Parameter/Analyte & $\begin{array}{l}\text { Medium } \\
\text { or } \\
\text { Matrix }\end{array}$ & $\begin{array}{l}\text { Analytical } \\
\text { Method }\end{array}$ & $\begin{array}{l}\text { Minimum } \\
\text { Reporting Limit } \\
\text { (MRL) }\end{array}$ & $\begin{array}{l}\text { Laboratory } \\
\text { Precision } \\
\text { (RPD) }^{a}\end{array}$ & $\begin{array}{c}\text { Percent } \\
\text { Recovery } \\
(\% \mathrm{R})^{\mathrm{b}}\end{array}$ \\
\hline \multicolumn{6}{|c|}{ ORGANICS } \\
\hline \multirow{2}{*}{$\begin{array}{l}\text { Total Volatile Organic } \\
\text { Compounds }\end{array}$} & Aqueous & \multirow{2}{*}{$8260 B^{c}$} & \multirow{2}{*}{$\begin{array}{c}\text { Parameter-specific } \\
\text { EQLs }\end{array}$} & \multirow{2}{*}{ Lab-specific $^{\mathrm{e}}$} & \multirow{2}{*}{ Lab-specific $^{\mathrm{e}}$} \\
\hline & Soil & & & & \\
\hline \multirow{2}{*}{$\begin{array}{l}\text { Total Semivolatile Organic } \\
\text { Compounds }\end{array}$} & Aqueous & \multirow{2}{*}{$8270 C^{c}$} & \multirow{2}{*}{$\begin{array}{c}\text { Parameter-specific } \\
\text { EQLs }\end{array}$} & \multirow{2}{*}{ Lab-specific $^{\mathrm{e}}$} & \multirow{2}{*}{ Lab-specific $^{e}$} \\
\hline & Soil & & & & \\
\hline \multirow{2}{*}{ Polychlorinated Biphenyls } & Aqueous & \multirow{2}{*}{$8082^{c}$} & \multirow{2}{*}{$\begin{array}{c}\text { Parameter-specific } \\
\text { EQLs }^{\dagger}\end{array}$} & \multirow{2}{*}{ Lab-specific $^{\mathrm{e}}$} & \multirow{2}{*}{ Lab-specific $^{\mathrm{e}}$} \\
\hline & Soil & & & & \\
\hline Pesticides & Solid & $8081^{c}$ & $\begin{array}{c}\text { Parameter-specific } \\
\text { EQLs }^{\dagger}\end{array}$ & Lab-specific $^{\mathrm{e}}$ & Lab-specific $^{e}$ \\
\hline \multicolumn{6}{|c|}{ INORGANICS } \\
\hline \multicolumn{6}{|c|}{ Total RCRA Metals, plus Beryllium } \\
\hline \multirow{2}{*}{ Arsenic } & Aqueous & $6010 B^{c}$ & $0.01 \mathrm{mg} / \mathrm{L}^{\mathrm{g}, \mathrm{h}}$ & $20^{h}$ & \multirow{12}{*}{$\begin{array}{c}\text { Matrix Spike } \\
\text { Recovery } \\
\text { at } \\
75-125^{\mathrm{h}}\end{array}$} \\
\hline & Soil & $6010 B^{c}$ & $1 \mathrm{mg} / \mathrm{kg}^{\mathrm{g}, \mathrm{h}}$ & $35^{g}$ & \\
\hline \multirow{2}{*}{ Barium } & Aqueous & $6010 \mathrm{~B}^{\mathrm{c}}$ & $0.1 \mathrm{mg} / \mathrm{L}^{\mathrm{g}, \mathrm{h}}$ & $20^{h}$ & \\
\hline & Soil & $6010 B^{c}$ & $10 \mathrm{mg} / \mathrm{kg}^{\mathrm{g}, \mathrm{h}}$ & $35^{g}$ & \\
\hline \multirow{2}{*}{ Beryllium } & Aqueous & $6010 B^{c}$ & $0.005 \mathrm{mg} / \mathrm{L}^{\mathrm{g}, \mathrm{h}}$ & $20^{h}$ & \\
\hline & Soil & $6010 B^{c}$ & $0.5 \mathrm{mg} / \mathrm{kg}^{\mathrm{g}, \mathrm{h}}$ & $35^{g}$ & \\
\hline \multirow{2}{*}{ Cadmium } & Aqueous & $6010 B^{c}$ & $0.005 \mathrm{mg} / \mathrm{L}^{\mathrm{g}, \mathrm{h}}$ & $20^{h}$ & \\
\hline & Soil & $6010 B^{c}$ & $0.5 \mathrm{mg} / \mathrm{kg}^{\mathrm{g}, \mathrm{h}}$ & $35^{g}$ & \\
\hline \multirow{2}{*}{ Chromium } & Aqueous & $6010 B^{c}$ & $0.01 \mathrm{mg} / \mathrm{L}^{\mathrm{g}, \mathrm{h}}$ & $20^{h}$ & \\
\hline & Soil & $6010 B^{c}$ & $1 \mathrm{mg} / \mathrm{kg}^{\mathrm{g}, \mathrm{h}}$ & $35^{g}$ & \\
\hline \multirow{2}{*}{ Lead } & Aqueous & $6010 B^{c}$ & $0.003 \mathrm{mg} / \mathrm{L}^{\mathrm{g}, \mathrm{h}}$ & $20^{h}$ & \\
\hline & Soil & $6010 B^{c}$ & $0.3 \mathrm{mg} / \mathrm{kg}^{\mathrm{g}, \mathrm{h}}$ & $35^{g}$ & \\
\hline
\end{tabular}


Table 3-7

Analytical Requirements for Chemical COPCs for CAU 118

(Page 2 of 2)

\begin{tabular}{|c|c|c|c|c|c|}
\hline Parameter/Analyte & $\begin{array}{l}\text { Medium } \\
\text { or } \\
\text { Matrix }\end{array}$ & $\begin{array}{l}\text { Analytical } \\
\text { Method }\end{array}$ & $\begin{array}{l}\text { Minimum } \\
\text { Reporting Limit } \\
\text { (MRL) }\end{array}$ & $\begin{array}{l}\text { Laboratory } \\
\text { Precision } \\
\text { (RPD) }^{\mathrm{a}}\end{array}$ & $\begin{array}{l}\text { Percent } \\
\text { Recovery } \\
(\% R)^{b}\end{array}$ \\
\hline \multirow{2}{*}{ Mercury } & Aqueous & $7470 A^{c}$ & $0.0002 \mathrm{mg} / \mathrm{L}^{\mathrm{g}, \mathrm{h}}$ & $20^{\mathrm{h}}$ & \multirow{6}{*}{$\begin{array}{c}\text { Matrix Spike } \\
\text { Recovery } \\
\text { at } \\
75-125^{\mathrm{h}}\end{array}$} \\
\hline & Soil & $7471 A^{c}$ & $0.1 \mathrm{mg} / \mathrm{kg}^{\mathrm{g}, \mathrm{h}}$ & $35^{9}$ & \\
\hline \multirow{2}{*}{ Selenium } & Aqueous & $6010 \mathrm{~B}^{\mathrm{c}}$ & $0.005 \mathrm{mg} / \mathrm{L}^{\mathrm{g}, \mathrm{h}}$ & $20^{h}$ & \\
\hline & Soil & $6010 \mathrm{~B}^{\mathrm{c}}$ & $0.5 \mathrm{mg} / \mathrm{kg}^{\mathrm{g}, \mathrm{h}}$ & $35^{9}$ & \\
\hline \multirow[b]{2}{*}{ Silver } & Aqueous & $6010 B^{c}$ & $0.01 \mathrm{mg} / \mathrm{L}^{\mathrm{g}, \mathrm{h}}$ & $20^{h}$ & \\
\hline & Soil & $6010 B^{c}$ & $1 \mathrm{mg} / \mathrm{kg}^{\mathrm{g}, \mathrm{h}}$ & $35^{9}$ & \\
\hline
\end{tabular}

See Table 3-6 for the analytical requirements for radionuclides.

${ }^{\text {a }}$ Precision is estimated from the RPD of the laboratory or field duplicates MSD and LCSD are spiked. It is calculated by: $\mathrm{RPD}=100 \times\left(\left|A_{1}-A_{2}\right|\right) /\left[\left(A_{1}+A_{2}\right) / 2\right]$, where $A_{1}=$ Concentration of the parameter in the initial sample aliquot, $A_{2}=$ Concentration of the parameter in the duplicate sample aliquot.

${ }^{b}$ Accuracy is assessed from the percent recovery $(\% R)$ of parameters spiked into a blank or sample matrix of interest, or from the recovery of surrogate compounds spiked into each sample. The recovery of each spiked parameter is calculated by: $\% R=100 x$ $\left(A_{s}-A_{u} / A_{n}\right)$, where $A_{s}=$ Concentration of the parameter in the spiked sample, $A_{u}=$ Concentration of the parameter in the unspiked sample, $A_{n}=$ Concentration increase that should result from spiking the sample.

${ }^{\mathrm{C}}$ EPA Test Methods for Evaluating Solid Waste Physical/Chemical Methods, 3rd Edition, Parts 1-4, (SW-846) CD ROM, Washington, D.C. (EPA,1996).

${ }^{d}$ Estimated Quantitation Limit as given in SW-846 (EPA, 1996).

${ }^{\mathrm{e}} \mathrm{RPD}$ and \%R Performance Criteria are developed and generated in-house by the laboratory according to approved laboratory procedures.

fEPA Contract Laboratory Program Statement of Work for Organic Analysis (EPA, 1999).

IIndustrial Sites Quality Assurance Project Plan (NNSA/NV, 2002a).

hEPA Contract Laboratory Program Statement of Work for Inorganic Analysis (EPA, 1994).

$\mathrm{EQL}=$ Estimated quantitation limit

LCSD = Laboratory control sample duplicate

$\mathrm{mg} / \mathrm{L}=$ Milligrams per liter

$\mathrm{mg} / \mathrm{kg}=$ Milligrams per kilogram

\author{
MSD = Matrix spike duplicate \\ N/A $=$ Not applicable \\ RCRA = Resource Conservation and Recovery Act \\ $\mathrm{RPD}=$ Relative percent difference
}

- Potential remediation waste.

- Environmental media where natural attenuation or biodegradation or construction/evaluation of barriers is considered.

\subsubsection{Spatial Boundaries}

Spatial boundaries are the maximum lateral and vertical extent of each expected contaminant at the CAS, including all media likely to come in contact with the environment. Contamination found beyond these boundaries may indicate a flaw in the CSM and may require re-evaluation of the CSM 
before the investigation can continue. Due to the nature of Area 27 and security, the existing fenced perimeter boundary or facility footprint will be used as the horizontal study boundary, as determined by the DQO process. The vertical boundaries will be $10 \mathrm{ft}$ bgs, or the extent of reach of a backhoe (approximately $15 \mathrm{ft}$ bgs).

\subsubsection{Practical Constraints}

Practical constraints that may affect the ability to perform work at the site include unforeseen or unsafe working conditions, worker health and safety, ongoing military activities at the NTS, inclement weather (i.e., high winds, rain, lightning, extreme heat), utilities, threatened or endangered animal and plants, unstable or steep terrain, and/or access restrictions.

\subsubsection{Define the Scale of Decision Making}

The scale of decision making in Decision I is defined as the CAS. Any COC detected at any location within the CAS will cause the determination that the CAS is contaminated and needs further evaluation. The scale of decision making for Decision II is defined as a contiguous area contaminated with any COC originating from the CAS. Resolution of Decision II requires this contiguous area to be bounded laterally and vertically.

\subsubsection{Step 5 - Develop a Decision Rule}

This step develops a decision rule (“If..., then...”) statement that defines the conditions under which possible alternative actions will be chosen. This step specifies the parameters that characterize the population of interest, specifies the FALs, confirms that analytical detection limits are capable of detecting FALs, and presents decision rules.

\subsubsection{Population Parameters}

For judgmental sampling results, the population parameter is the observed concentration of each contaminant from each individual analytical sample. Each sample result will be compared to the FALs to determine the appropriate resolution to Decision I and Decision II. For Decision I, a single sample result for any contaminant exceeding a FAL would cause a determination that a COC is present within the CAS. 
The Decision II population parameter is an individual analytical result from a bounding sample. For Decision II, a single bounding sample result for any contaminant exceeding a FAL would cause a determination that the contamination is not bounded.

\subsubsection{Decision Rules}

The decision rules applicable to both Decision I and Decision II are:

- If COC contamination is inconsistent with the CSM or extends beyond the spatial boundaries identified in Section 3.1.4.2, then work will be suspended and the investigation strategy will be reconsidered. If a COC is present, is consistent with the CSM, and is within spatial boundaries, then the decision will be to continue sampling to define the extent.

The decision rules for Decision I are:

- If a COC exists in environmental media or potential source materials exist that could impact human health or the environment, remove the media or define the extent for the Use Restriction (Decision II).

- If no COCs exist, limit Use Restriction to the structure footprints.

The decision rules for Decision II are:

- If sufficient information is available to meet closure objectives, no additional data are needed, and the closure strategy of closure in place will be implemented.

- If sufficient information is not available to meet closure objectives, collect data needed.

\subsubsection{Soil Sample Action Levels}

The PALs presented in this section are to be used for site screening purposes for soils. They are not necessarily intended to be used as cleanup action levels or FALs. However, they are useful in screening out contaminants that are not present in sufficient concentrations to warrant further evaluation and, therefore, streamline the consideration of remedial alternatives. The risk-based corrective action (RBCA) process used to establish FALs is described in the Industrial Sites Project Establishment of Final Action Levels (NNSA/NSO, 2006). This process conforms with Nevada Administrative Code (NAC) Section 445A.227 (NAC, 2005b), which lists the requirements for sites with soil contamination. For the evaluation of corrective actions, NAC Section 445A.22705 
(NAC, 2005c) requires the use of American Society for Testing and Materials (ASTM) Method E 1739-95 (ASTM, 1995) to "conduct an evaluation of the site, based on the risk it poses to public health and the environment, to determine the necessary remediation standards (i.e., FALs) or to establish that corrective action is not necessary."

This RBCA process defines three tiers (or levels) of evaluation involving increasingly sophisticated analyses:

- Tier 1 evaluation - sample results from source areas (highest concentrations) are compared to action levels based on generic (non-site-specific) conditions (i.e., the PALs established in the SAFER plan). The FALs may then be established as the Tier 1 action levels, or the FALs may be calculated using a Tier 2 evaluation.

- Tier 2 evaluation - conducted by calculating Tier 2 Site-Specific Target Levels (SSTLs) using site-specific information as inputs to the same or similar methodology used to calculate Tier 1 action levels. The Tier 2 SSTLs are then compared to individual sample results from reasonable points of exposure (as opposed to the source areas as is done in Tier 1) on a point-by-point basis. Total concentrations of total petroleum hydrocarbons will not be used for risk-based decisions under Tier 2 or Tier 3. Rather, the individual chemicals of concern will be compared to the SSTLs.

- Tier 3 evaluation - conducted by calculating Tier 3 SSTLs on the basis of more sophisticated risk analyses using methodologies described in ASTM Method E 1739-95 that consider site-, pathway-, and receptor-specific parameters.

The comparison of laboratory results to FALs and the evaluation of potential corrective actions will be included in the investigation report. The FALs will be defined (along with the basis for their definition) in the investigation report.

\subsection{Chemical PALs}

Except as noted herein, the chemical PALs are defined as the EPA Region 9 Risk-Based Preliminary Remediation Goals (PRGs) for chemical contaminants in industrial soils (EPA, 2005). Background concentrations for RCRA metals will be used instead of PRGs when natural background concentrations exceed the PRG, as is often the case with arsenic on the NTS. Background is considered the average concentration plus two standard deviations of the average concentration for sediment samples collected by the Nevada Bureau of Mines and Geology throughout the Nevada Test and Training Range (formerly the Nellis Air Force Range) (NBMG, 1998; Moore, 1999). For 
detected chemical COPCs without established PRGs, the protocol used by the EPA Region 9 in establishing PRGs (or similar) will be used to establish PALs. If used, this process will be documented in the investigation report.

\subsection{Radionuclide PALs}

The PALs for radiological contaminants (other than tritium) are based on the National Council of Radiation Protection and Measurements (NCRP) Report No. 129 recommended screening limits for construction, commercial, industrial land-use scenarios (NCRP, 1999) scaled to 25 millirem per year (mrem/yr) dose constraint (Murphy, 2004) and the generic guidelines for residual concentration of radionuclides in DOE Order 5400.5 (DOE, 1993). These PALs are based on the construction, commercial, and industrial land-use scenario provided in the guidance and are appropriate for the NTS based on the future land use scenario as presented in Section 3.1.1.2. The PAL for tritium is based on the UGTA Project limit of 400,000 picocuries per liter (pCi/L) for discharge of water containing tritium (NNSA/NV, 2002b).

Solid media such as concrete and/or structures may pose a potential radiological exposure risk to site workers if contaminated. The radiological PAL for solid media will be defined as the unrestricted-release criteria defined in the NV/YMP RadCon Manual (NNSA/NSO, 2004).

\subsubsection{Measurement and Analysis Sensitivity}

The measurement and analysis methods listed in Section 3.1.3 and in the Industrial Sites QAPP (NNSA/NV, 2002a) are capable of measuring analyte concentrations at or below the corresponding FAL for each COPC. See Section 7.2 for additional details.

\subsubsection{Step 6 - Specify the Tolerable Limits on Decision Errors}

The purpose of this step is to specify performance criteria for the decision rule. Setting tolerable limits on decision errors requires the planning team to weigh the relative effects of a threat to human health and the environment, expenditure of resources, and consequences of an incorrect decision.

For judgmental sampling designs, Section 7.1 of the EPA QA/G-4HW (EPA, 2000a) guidance states that quantitative statements about data quality will be limited to measurement error. Measurement 
error is influenced by imperfections in the measurement and analysis system. Random and systematic measurement errors are introduced in the measurement process during physical sample collection, sample handling, sample preparation, sample analysis, and data reduction. If measurement errors are not controlled, they may lead to errors in making the DQO decisions.

This section provides an assessment of the possible outcomes of DQO decisions and the impact of those outcomes if the decisions are in error.

The baseline condition (i.e., null hypothesis) and alternative condition for Decision I are:

- Baseline condition - A COC is present.

- Alternative condition - A COC is not present.

The baseline condition (i.e., null hypothesis) and alternative condition for Decision II are as follows:

- Baseline condition - The extent of a COC has not been defined and closure objectives were not met.

- Alternative condition - The extent of a COC has been defined and closure objectives were met.

Decisions and/or criteria have false negative or false positive errors associated with their determination. The impact of these decision errors and the methods that will be used to control these errors are discussed in the following subsections. In general terms, confidence in DQO decisions based on judgmental sampling results will be established qualitatively by:

- The development of and concurrence of CSMs (based on process knowledge) by stakeholder participants during the DQO process;

- Testing the validity of CSMs based on investigation results; and

- Evaluating the quality of the data based on Data Quality Indicator (DQI) parameters.

\subsubsection{False Negative Decision Error}

The false negative decision error would mean deciding that a COC is not present when it actually is (Decision I), or deciding that the extent of a COC has been defined when it has not (Decision II). In both cases, the potential consequence is an increased risk to human health and environment. The 
false negative decision error (where consequences are more severe) for judgmental sampling designs is controlled by meeting these criteria:

- For Decision I, having a high degree of confidence that the sample locations selected will identify COCs if present anywhere within the CAS. For Decision II, having a high degree of confidence that the sample locations selected will identify the extent of COCs.

- Having a high degree of confidence that analyses conducted will be sufficient to detect any COCs present in the samples.

- Having a high degree of confidence that the dataset is of sufficient quality and completeness.

To satisfy the first criterion, Decision I samples must be collected in areas most likely to be contaminated by COCs (supplemented by random samples where appropriate). Decision II samples must be collected in areas that represent the lateral and vertical extent of contamination (above FALs). The following characteristics must be considered to control decision errors for the first criterion:

- Source and location of release

- Chemical nature and fate properties

- Physical transport pathways and properties

- Hydrologic drivers

These characteristics were considered during the development of the CSM and selection of sampling locations for the site confirmation phase. The field-screening methods and biasing factors listed in Section 3.1.3.2.1 will be used to further ensure that appropriate sampling locations are selected to meet these criteria. Radiological survey instruments and field-screening equipment will be calibrated and checked in accordance with the manufacturer's instructions and approved procedures. The investigation report will present an assessment on the DQI of representativeness that samples were collected from those locations that best represent the populations of interest as defined in Section 3.1.4.1.

To satisfy the second criterion, Decision I samples will be analyzed for the chemical and radiological parameters listed in Section 3.1.2. Decision II samples will be analyzed for those chemical and radiological parameters that identified unbounded COCs. The DQI of sensitivity will be assessed for all analytical results to ensure that all sample analyses had measurement sensitivities (detection limits) that were less than or equal to the corresponding FALs. If this criterion is not achieved, the 
affected data will be assessed (for usability and potential impacts on meeting site characterization objectives) in the investigation report.

To satisfy the third criterion, the entire dataset, as well as individual sample results, will be assessed against the DQIs of precision, accuracy, comparability, and completeness as defined in the Industrial Sites QAPP (NNSA/NV, 2002a) and in Section 7.0 of the SAFER plan. The DQIs of precision and accuracy will be used to assess overall analytical method performance as well as to assess the need to potentially “flag” (qualify) individual contaminant results when corresponding quality control (QC) sample results are not within the established control limits for precision and accuracy. Data qualified as estimated for reasons of precision or accuracy may be considered to meet the constituent performance criteria based on an assessment of the data. The DQI for completeness will be assessed to ensure that all data needs identified in the DQO have been met. The DQI of comparability will be assessed to ensure that all analytical methods used are equivalent to standard EPA methods so that results will be comparable to regulatory action levels that have been established using those procedures. Strict adherence to established procedures and quality assurance (QA)/QC protocol protects against false negatives. Site-specific DQIs are discussed in more detail in Section 7.0.

To provide information for the assessment of the DQIs of precision and accuracy, the following quality control samples will be collected as required by the Industrial Sites QAPP

(NNSA/NV, 2002a):

- Field duplicates (one per 20 environmental samples or one per CAS per matrix, if less than 20 collected)

- Laboratory QC samples (one per 20 environmental samples or one per CAS, if less than 20 collected, not required for all radionuclide measurements)

\subsubsection{False Positive Decision Error}

The false positive decision error would mean deciding that a COC is present when it is not, or accepting that the extent of a COC has not been defined when it actually has, resulting in increased costs for unnecessary sampling and analysis.

False positive results are typically attributed to laboratory and/or sampling/handling errors that could cause cross contamination. To control against cross contamination, decontamination of sampling 
equipment will be conducted according to established and approved procedures and only clean sample containers will be used. To determine whether a false positive analytical result may have occurred, the following quality control samples will be collected as required by the Industrial Sites QAPP (NNSA/NV, 2002a):

- Trip blanks (one per sample cooler containing volatile organic compound [VOC] environmental samples)

- Equipment blanks (one per sampling event for each type of decontamination procedure)

- Source blanks (one per source lot per sampling event)

- Field blanks (minimum of one per CAS, additional if field conditions change)

\subsubsection{Step 7 - Optimize the Design}

This step is used to evaluate information from the previous steps and choose the most resource-effective design that meets all DQOs. As additional data or information is obtained, this step will be re-evaluated and refined, if necessary, to reduce uncertainty and increase the confidence that the SAFER CAI has met its intended goals. In general, the COCs will be addressed by executing the following closure strategy:

- $\quad$ Site Preparation (completed)

- Install temporary power, office trailer, lighting, and ventilation (complete).

- Clean on-site structures for Hantavirus (ongoing, as necessary).

- Site Confirmation (partially completed)

- Collect building media samples such as concrete and paint chips (ongoing).

- Collect radiological surveys, smears and H\&S swipes, and air monitoring data (ongoing).

- Inventory material and debris in each building (ongoing).

- DQO/SAFER process

- Establish DQO criteria and develop SAFER plan.

- Hazard Reduction/Waste Management

- Remove PCB and non-PCB oils, lead and mercury components (e.g., lead sheet, switches, solder), asbestos, and other hazardous materials, as practical.

- Place debris from Building 5410 and the Wooden Shed in Building 5400 for entombment, as appropriate. 
- Demolition, Disposal and Final Investigation

- Demolish/dispose of Buildings 5400A and 5410 and their contents to their concrete slabs.

- Demolish/dispose of Wooden Shed to grade.

- Sample soils adjacent to the Building 5410 slab and from under the Wooden Shed.

- Survey Building 5400A and Building 5410 concrete slabs.

- $\quad$ Prepare Structure for Final End-State

- Fill openings/pathways (e.g., ducts, sumps, overpressure well) with grout and/or concrete.

- Fill/entomb Building 5400, including sumps, basement reactor room, and tunnel with flowable grout.

- Implement engineering specifications to prevent weathering and precipitation infiltration (i.e., grade surrounding area to ensure surface water flows away from buildings).

- Apply appropriate Use Restriction.

This section provides the general approach for obtaining the information necessary to resolve Decision I and Decision II. A judgmental sampling scheme will be implemented to select sample locations and evaluate analytical results for CAU 118. Sections 3.1.7.1.1 through 3.1.7.1.4 describe the proposed corrective actions based on metal, paint, oil, gas, and HEPA filter samples taken from the structures at CAU 118 during the site confirmation phase.

\subsubsection{Corrective Actions for CAS 27-41-01, CAU 118}

This section describes specific corrective action activities for each structure located at CAS 27-41-01.

\subsection{Building 5400A}

Closure activities to be completed at Building 5400A, High Bay, are detailed below:

- Remove all liquids and hazardous waste, LLW, and/or mixtures of hazardous and LLW (i.e., MLLW) as required, per NTSWAC (NNSA/NSO, 2005) for the superstructure.

- Freon systems and oils from the overhead crane were removed in April 2006. 
- The building contains ACM in the form of one workbench. All ACM will be removed by certified asbestos workers, according to local, state, and federal regulations.

- Remove all other items identified as hazardous waste, LLW, or mixed waste (e.g., mercury switches, lead-acid batteries, lead sheet attached to plywood board).

- Demolish and dispose of the High Bay superstructure.

- Demolition and disposal includes the overhead crane, external HVAC system and stacks, and all associated fixtures.

- Building structure materials will be disposed of in a sanitary landfill on site at the NTS.

- The High Bay concrete floor will be left in place to aid in the stabilization of Building 5400. Pathways such as holes and pipes leading to Building 5400 will be filled with flowable grout.

- Survey and post (as necessary) the remaining concrete slab following D\&D activities as instructed in the NV/YMP RadCon Manual (NNSA/NSO, 2004).

- Apply Use Restrictions, as required.

\subsection{Building 5400}

Closure activities to be completed at Building 5400, Reactor Building, are detailed below:

- All liquids and gases will be removed, to the extent possible (i.e., tank and process lines will be emptied by commonly employed practices. A sheen or residual material may be left).

- Freon, and oils from the overhead crane and robotic arm were removed in April 2006.

- PCB and radioactively contaminated hydraulic oil was removed in May 2006. Following removal of oil, systems were triple-rinsed with fresh diesel as per TSCA regulations (CFR, 2003c). A minimum of 10 percent of the total system volume was achieved per rinse. A total of 60 gallons of diesel was injected into the hydraulic system and subsequently recovered.

- Debris from Building 5410 and the Wooden Shed may be placed in Building 5400 for entombment if it is determined to be compatible (i.e., the debris is not hazardous or mixed waste, consists of the same radionuclides, and will not increase void space after entombment). 
- Fill Building 5400 and associated utility voids with flowable grout according to the following plan:

- Underground ventilation ducts, the hydraulic line chase leading to Building 5410 and the exterior HPEA/stack.

- Overpressure well.

- Sump, basement, stairwell, lower portion of reactor stand and associated systems.

- The reactor room and all associated debris and fixtures will be filled from a 3-ft access port in the ceiling (the High Bay floor). The reactor stand, lead wall and any associated activated or contaminated solid media (e.g., tools, equipment, electronics, test canisters) will be left in the room and filled in place.

- The access tunnel to Building 5400 and all associated debris and fixtures from the reactor room will be filled to the tunnel entrance. The entrance to the tunnel will be sealed closed.

- Implement engineering controls (i.e., grade the surrounding area to ensure surface water flows away from buildings) as needed to protect the sub-surface filled structure from weathering and infiltration.

\subsection{Building 5410}

Additional information is needed to assess planned corrective action activities at Building 5410. Currently planned activities are detailed below:

- Characterize internal building structure and contents.

- Remove or stabilize contamination, as appropriate.

- Remove building components and dispose of as waste or, if compatible, place in Building 5400 before stabilization.

- Demolish and dispose of the building structure to the concrete slab. It is anticipated that the structure may be disposed of at an NTS landfill.

- $\quad$ Survey the remaining concrete slab as per instructions in the NV/YMP RadCon Manual (NNSA/NSO, 2004). Decontamination of the slab following building demolition is not anticipated to be needed.

- Apply Use Restrictions, as required. 


\subsection{Wooden Shed}

Closure activities to be completed at the Wooden Shed are detailed below:

- Characterize internal building structure and contents.

- Remove building components and dispose of as waste or, if compatible, place in Building 5400 before stabilization.

- Demolish and dispose of the shed. It is anticipated that the structure may be disposed of at an NTS sanitary landfill.

- Sample any soil stains discovered underneath the shed. Results exceeding FALs will require posting.

- Apply Use Restrictions, as required.

\subsection{Ancillary Structures}

Closure activities to be completed at the Wooden Shed are detailed below:

- Remove concrete stairs, railings, perimeter fencing, bollards, and turnstiles.

\subsection{Results of the DQO Analysis}

\subsubsection{Action Level Determination and Basis}

Action levels for soil samples are discussed in Section 3.1.5.3. Action levels for chemicals are defined as the EPA Region 9 risk-based preliminary remediation goals for chemical constituents in industrial soils (EPA, 2005). Action levels for radiological contaminants are based on the NCRP Report No. 129-recommended screening limits for construction, commercial, and industrial land-used scenarios (NCRP, 1999) scaled to a $25 \mathrm{mrem} / \mathrm{yr}$ dose constraint (Murphy, 2004), and the generic guidelines for residual concentrations of radionuclides in DOE Order 5400.5 (DOE, 1993). The radiological action level for solid media will be defined as the unrestricted release criteria defined in Table 4-2 of the NV/YMP RadCon Manual (NNSA/NSO, 2004). Remaining radiological contamination will be posed as per the NV/YMP RadCon Manual. 


\subsubsection{Hypothesis Test}

Page 56 of 98

Only valid data from radiological surveys and laboratory analytical results will be used to determine if contamination is present. The null hypothesis for Decision I is that a COC is present. The two types of decision errors are false negative and false positive. A false negative decision error would occur if contamination is determined not to be present when it actually is (Decision I), or if it is determined that the extent of a COC has been defined when it has not (Decision II). In both cases, the potential consequence is an increased risk to human health and the environment. A false positive decision error would occur if contamination is determined to be present when it is not, or if it is determined that the extent of a COC has not been defined when it actually has. In both cases, the potential consequence is an increase in costs for unnecessary sampling and analysis.

Hypothesis tests for the site are discussed in more detail in Section 3.1.6.

\subsubsection{Statistical Model}

Because samples will be collected based on a biased (judgmental) sampling scheme, a statistical model for collecting samples is not applicable.

\subsubsection{Design Description/Option}

Section 3.1.7 describes the closure strategy that will be used to address the presence of any COCs found on site. A judgmental sampling scheme will be implemented to select sample locations and evaluate analytical results. Sampling locations are discussed in more detail in Section 3.1.3.2.1. Sections 3.1.7.1.1 through 3.1.7.1.4 describe specific corrective actions for each structure on site.

Biased (judgmental) soil samples will be collected as needed. Locations for samples will be chosen based on process knowledge and visual inspection of the site (e.g., soil staining). Systematic radiological surveys will be conducted to identify radiological contamination.

\subsubsection{Conceptual Site Model and Drawing}

The CSM is presented in Section 3.1.1.2. A graphical representation of the CSM is shown in Figure 3-1. 


\subsection{Field Activities and Closure Objectives}

This section of the SAFER plan provides a description of the field activities and closure objectives for CAU 118. The objective for the field activities is to determine whether COCs exist. If remediation is determined to be feasible, then the extent of COCs will be determined so that a closure alternative may be implemented. All sampling activities will be (or have been) conducted in compliance with the Industrial Sites QAPP (NNSA/NV, 2002a) and other applicable, approved procedures and instructions.

Before beginning the corrective action investigation and site closure fieldwork, the following activities will be (or have been) completed:

- Collect photographs of on-site structures.

- $\quad$ Review preliminary assessment materials and process knowledge.

- $\quad$ Obtain additional data as needed to support project planning.

- $\quad$ Prepare a Site-Specific Field Work Permit (FWP).

- $\quad$ Prepare Field Instruction (FI).

- $\quad$ Review and approve all related M\&O and subcontractor work packages.

Closure of CAU 118 will be accomplished by completing the following activities:

- $\quad$ Site Preparation (completed)

- $\quad$ Site Confirmation (partially completed)

- DQO/SAFER process

- Hazard Reduction/Waste Management

- Prepare Structure for Final End-State

For further details on closure activities, see Section 3.1.7. 


\subsection{Contaminants of Potential Concern}

The COPCs for CAU 118 are defined as the list of constituents represented by the analytical methods identified in Table 3-3 for Decision I environmental samples taken at CAS 27-41-01. The constituents reported for each analytical method are listed in Table 3-4.

The list of COPCs is intended to encompass all of the contaminants that could potentially be present at the CAS, and was generated during the planning process through the review of site history, process knowledge, personal interviews, past investigation efforts (where available), and inferred activities associated with the CAS.

Sampling that took place during site confirmation activities was used to confirm the presence of some suspected COPCs. The types of samples collected during the Site Confirmation are described in Section 2.2. Tables 2-1 and 2-2 provide summaries of the radiological and chemical contaminants identified in each structure from these samples. Based on analytical results and process knowledge, the COPCs include:

- Radionuclides

- PCBs

- RCRA metals

- ACM

- Beryllium

- Freon

Table 4-1 provides a list of components containing the identified COPCs and identifies whether the item(s) will be removed or left in place.

\subsubsection{Radionuclides}

Radionuclide COPCs identified through a review of site history and process knowledge include: tritium, C-14, Cl-36, Fe-55, Eu-152, Eu-154, Eu-155, Co-57, Co-60, Ni-63, Sr-90, Cs-137, isotopic uranium, isotopic plutonium, plutonium-241, and Am-241 (SNJV, 2006). The radiological COPCs are quantified based on the nature and extent measured:

- Fixed and removable contamination (within and on surfaces)

- Activated contamination (within concrete and other activated materials)

- Volumetric contamination (within oils) 
Concrete, steel, and aluminum from building structures, and tools and equipment stored in the Building 5400 access tunnel are considered radiologically impacted from neutron activation that took place during reactor operation.

Radionuclide contaminants confirmed by analytical results from Site Confirmation sampling include: Co-60, Cs-137, Eu-152, Eu-155, Fe-55, tritium, Ni-63, Pu-239, Sr-90, U-234, U-235, and U-238. Maximum activities/concentrations of specific radionuclide contaminants by building and sample type are presented in Table 2-1.

Several of the isotopes identified in historical information and through process knowledge are from test materials that were brought into and out of the reactor room in sealed test canisters. These materials did not remain in the Reactor Building, and therefore were not detected in samples collected in the Site Confirmation. Differences in the plutonium isotopes seen may also be attributed to the fact that because the reactor operated in short bursts and did not provide a continuous neutron flux, which explains the absence of Pu-241 in the samples.

Refer to Table 4-1 for a list of source material containing radionuclide COPCs, and how such material will be handled during the site closure.

\subsubsection{Polychlorinated Biphenyls}

Polychlorinated biphenyls were identified in samples of oil, paint, and swipes taken during the Site Confirmation. Maximum values of PCBs (Aroclor) found at CAU 118 by building and sample type are presented in Table 2-2. Articles and/or containers containing oils contaminated with PCBs will be treated as shown in Table 4-1 and discussed in Section 6.2.5.1.

\subsubsection{Resource Conservation and Recovery Act Metals}

\subsubsection{Lead}

In addition to traces of lead found in samples taken during Site Confirmation, lead is also contained in solder within electrical components, lead-acid batteries, ballast, a lead sheet attached to a plywood board in Building 5400A, and the lead shielding wall in Building 5400. Maximum values of lead found at CAU 118 during Site Confirmation by building and sample type are presented in Table 2-2. 
Table 4-1

\section{Plans for Disposal of Contaminated Items}

(Page 1 of 2)

\begin{tabular}{|c|c|c|c|}
\hline \multirow{2}{*}{ Contaminant } & \multicolumn{2}{|c|}{ Source Material } & \multirow{2}{*}{ Justification for Leaving in Place } \\
\hline & Remove & Leave in Place & \\
\hline Radionuclides & Radiological sources & $\begin{array}{l}5400 \text { building structural } \\
\text { material and other } \\
\text { radiologically impacted } \\
\text { items }\end{array}$ & $\begin{array}{l}\text { Removal and disposal of all the radiologically impacted building materials (e.g., } \\
\text { concrete, steel) would be very resource intensive and create significant safety } \\
\text { hazards for workers. Closure in place with administrative controls is consistent } \\
\text { with past practices for CASs where the removal of contaminated waste material } \\
\text { is not practical, where safeguards can be put in place to protect workers and the } \\
\text { public, and where the contamination will not migrate to a location where future } \\
\text { exposure might occur. The potential migration of contaminants to the } \\
\text { environment will be eliminated by stabilization of the radionuclides in place by the } \\
\text { grout. Future exposure to site workers will be eliminated by grouting the } \\
\text { subsurface structure to eliminate access, and by controlling activities that can } \\
\text { cause exposure to site workers by implementing the planned Use Restriction. }\end{array}$ \\
\hline $\begin{array}{l}\text { Polychlorinated } \\
\text { Biphenyls }\end{array}$ & $\begin{array}{l}\text { Overhead crane and } \\
\text { Pydraul hydraulic } \\
\text { system oils } \\
\text { (removed April 2006) }\end{array}$ & 5400 interior paint & $\begin{array}{l}\text { Removal and disposal of the paint would be very resource intensive and create } \\
\text { significant safety hazards for workers without producing a corresponding benefit } \\
\text { in terms of reducing the overall risk at the site upon closure. The potential } \\
\text { migration of contaminants to the environment will be eliminated by stabilization of } \\
\text { the PCBs in place by the grout. Future exposure to site workers will be } \\
\text { eliminated by grouting the subsurface structure to eliminate access, and by } \\
\text { controlling activities that can cause exposure to site workers by implementing the } \\
\text { planned Use Restriction. }\end{array}$ \\
\hline Lead & $\begin{array}{l}\text { Lead sheet in } 5400 \mathrm{~A} \text {, } \\
\text { lead-acid batteries }\end{array}$ & $\begin{array}{l}79,000-\mathrm{lb} \text { lead } \\
\text { shielding wall in } 5400 \text {, } \\
\text { lead in } 5400 \text { building } \\
\text { material (solids), } 5400 \\
\text { interior paint, solder in } \\
\text { electrical components }\end{array}$ & $\begin{array}{l}\text { Removal and disposal of the lead wall, building materials, interior paint, and/or } \\
\text { solder would be very resource intensive and create significant safety hazards for } \\
\text { workers without producing a corresponding benefit in terms of reducing the } \\
\text { overall risk at the site upon closure (i.e., a Use Restriction will already be required } \\
\text { for the radionuclides). For more detail on the justification for leaving lead in } \\
\text { place, see Appendix C and Appendix D. The potential migration of contaminants } \\
\text { to the environment will be eliminated by stabilization of the lead in place by the } \\
\text { grout. Future exposure to site workers will be eliminated by grouting the } \\
\text { subsurface structure to eliminate access, and by controlling activities that can } \\
\text { cause exposure to site workers by implementing the planned Use Restriction. }\end{array}$ \\
\hline
\end{tabular}


Table 4-1

Plans for Disposal of Contaminated Items

(Page 2 of 2)

\begin{tabular}{|c|c|c|c|}
\hline \multirow{2}{*}{ Contaminant } & \multicolumn{2}{|c|}{ Source Material } & \multirow{2}{*}{ Justification for Leaving in Place } \\
\hline & Remove & Leave in Place & \\
\hline Mercury & $\begin{array}{l}\text { Mercury switches, } \\
\text { light bulbs }\end{array}$ & N/A & N/A \\
\hline Other RCRA Metals & N/A & 5400 interior paint & $\begin{array}{l}\text { Removal and disposal of the paint would be very resource intensive and create } \\
\text { significant safety hazards for workers without producing a reciprocal benefit in } \\
\text { terms of reducing the overall risk at the site upon closure. The potential migration } \\
\text { of contaminants to the environment will be eliminated by stabilization of the paint } \\
\text { and associated contaminants in place by the grout. Future exposure to site } \\
\text { workers will be eliminated by grouting the subsurface structure to eliminate } \\
\text { access, and by controlling activities that can cause exposure to site workers by } \\
\text { implementing the planned Use Restriction. }\end{array}$ \\
\hline $\begin{array}{c}\text { Asbestos-Containing } \\
\text { Materials }\end{array}$ & 5400A tabletop & N/A & N/A \\
\hline Freon & $\begin{array}{l}\text { 5400A HVAC, } \\
\text { 5400A refrigerant } \\
\text { system, } 5400 \\
\text { refrigerant system } \\
\text { (removed April 2006) }\end{array}$ & N/A & N/A \\
\hline
\end{tabular}


Table 4-1 provides a list of source material containing lead, and how such material will be handled during the site closure. Lead components that can be readily removed (e.g., loose debris, lead-acid batteries) will be radiologically surveyed, removed, managed, or disposed of as described in Section 6.2.5.1.

\subsubsection{Mercury}

In addition to traces of mercury found in samples taken during Site Confirmation, items potentially containing mercury include fluorescent light bulbs, switches, thermostats, circuit boards, and instrumentation. Maximum values of mercury found at CAU 118 during Site Confirmation by building and sample type are presented in Table 2-2. Table 4-1 provides a list of source material containing mercury, and how such material will be handled during the site closure. Items containing mercury will be identified, removed, and disposed of as described in Section 6.2.4, before demolition.

\subsubsection{Other RCRA Metals}

Traces of arsenic, barium, cadmium, chromium, selenium, and silver were also identified in Site Confirmation samples. Maximum concentrations of these constituents by building and sample type are presented in Table 2-2. Table 4-1 provides a list of source material containing RCRA contaminants, and how such material will be handled during the site closure.

\subsubsection{Beryllium}

Beryllium is considered a COPC only from an historical perspective (CAU 118 is listed as a beryllium legacy site). No machining, milling, or destruction of material containing beryllium is known to have occurred at CAS 27-41-01. Beryllium was not identified in samples taken during the Site Confirmation.

\subsubsection{Asbestos-Containing Material}

Refer to Section 2.2 for information on samples taken during Site Confirmation to confirm the presence of ACM. Disposal options for ACM found on site may vary depending on other contaminants present in the waste. All ACM will be removed before demolition by trained asbestos workers and disposed of properly. Removal of ACM is anticipated to be a minor effort. Table 4-1 
provides a list of source material containing ACM, and how such material will be handled during the site closure. Disposal of ACM is discussed further in Section 6.2.5.2.

\subsubsection{Freon}

Freon was identified during the site confirmation phase in an HVAC system on the exterior of the High Bay, in a refrigerant system inside of the High Bay, and in a refrigerant system in the reactor room (see Section 2.2). Table 4-1 provides a list of source material containing Freon, and how such material will be handled during the site closure. All Freon gas/liquids were drained, containerized, sampled, managed, and will be recycled or disposed of appropriately. Disposal of Freon is discussed further in Section 6.3.1.

\subsubsection{Other Hazardous Constituents}

Contaminants of potential concern identified from historical documentation include gadolinium paint used as a neutron absorber on Building 5400 equipment (Kelly, 2000), and methanol in Building 5410 (IT, 1996). Gadolinium is a non-toxic metal used as a neutron absorber to protect equipment during reactor bursts. The presence of methanol in Building 5410 will be confirmed through investigation.

Items found containing hazardous materials will be removed, managed, and disposed of appropriately. Refer to Table 4-1 for a list of source material containing other hazardous constituents, and how such material will be handled during the site closure. If additional hazardous materials are encountered that have not been previously identified, they will be removed, managed, and disposed of appropriately.

\subsection{Remediation}

The DQOs developed for CAU 118 identified data gaps that require additional data collection before identifying and implementing the preferred closure alternative for the CAS. Further characterization data are needed for Building 5410, the Wooden Shed and surface/near-surface soils surrounding Building 5400. Data for Buildings 5400 and 5400A were collected as part of a biased sampling plan carried out during the site confirmation phase. A decision point approach, based on the DQOs, for making remediation decisions is summarized in Figure 1-3. The presence of contamination, if any, is assumed to be confined to the spatial boundaries of the sites as defined in the DQO process and CSM. 
If COCs are identified within the CAS based on the initial investigation results, CAS 27-41-01 will be further assessed before implementing closure activities. If COPCs are not present at concentrations exceeding FALs, the CAS will be recommended for no further action. The objective of the initial investigation strategy is to determine whether COCs are present. Laboratory analytical results will be used to confirm the presence or absence of COCs.

If COCs are present, or it is decided that COCs may be present based on the presence of biasing factors, an interim action of removal for disposal may be implemented and additional verification samples taken from biased locations within the excavation.

The judgmental sampling strategy is presented in Section 3.0. Predetermined biased sample locations may be justified by the Site Supervisor, based on the criteria for satisfying DQO data needs listed in Section 3.0. Additional samples may be collected for waste management characterization and disposal purposes.

The initial sampling strategy targeted locations and media most likely to be contaminated. Biasing factors were used along with available process knowledge for choosing the sample locations for this investigation. Biasing factors considered in selecting locations for analytical samples at CAU 118 (and which will be considered when collecting samples for additional characterization or for waste management and disposal purposes) are detailed in Section 3.0.

The following remediation activities for CAU 118 have already been completed:

- $\quad$ Site Preparation (completed)

- Install temporary power, office trailer, lighting, and ventilation (complete).

- Clean on-site structures for Hantavirus (ongoing, as necessary).

- $\quad$ Site Confirmation (partially completed)

- Collect building media samples such as concrete and paint chips (ongoing).

- Collect radiological surveys, smears and H\&S swipes, and air monitoring data (ongoing).

- Inventory material and debris in each building (ongoing).

The remediation activities listed below must still be completed to close CAU 118:

- DQO/SAFER process. 
- Establish DQO criteria and develop SAFER plan.

- Hazard Reduction/Waste Management

- Remove PCB and non-PCB oils, lead and mercury components (e.g., lead sheet, switches, solder), asbestos, and other hazardous materials, as practical.

- Place debris from Building 5410 and the Wooden Shed in Building 5400 for entombment, as appropriate.

- Demolition, Disposal and Final Investigation

- Demolish/dispose of Buildings 5400A and 5410 and their contents to their concrete slabs.

- Demolish/dispose of Wooden Shed to grade.

- Sample soils adjacent to the Building 5410 slab and from under the Wooden Shed.

- Survey Building 5400A and Building 5410 concrete slabs.

- Prepare Structure for Final End-State

- Fill openings/pathways (e.g., ducts, sumps, overpressure well) with grout and/or concrete.

- Fill/entomb Building 5400, including sumps, basement reactor room, and tunnel with flowable grout.

- Implement engineering specifications to prevent weathering and precipitation infiltration (i.e., grade surrounding area to ensure surface water flows away from buildings).

- Apply appropriate Use Restriction.

The activities required to close CAU 118 are described in more detail in the following sections.

\subsubsection{Site Preparation}

Initial site preparation activities took place in early 2006. At that time, activities were performed to mitigate existing hazardous conditions and provide a safe and efficient work environment at the facility. Temporary lighting systems were installed in the access tunnel, reactor room and basement of Building 5400. A ventilation system extending from the basement of Building 5400 through Building 5400A was also installed. An office trailer was placed on site southwest of Building 5400/5400A. Rodent droppings (Hantavirus potential) were cleared and bagged from Buildings 
5400, 5400A and the Wooden Shed. Rodent droppings found in Building 5410 will be cleared and bagged in accordance with appropriate regulatory requirements. The absence of voltage in power lines entering and throughout the structures will be verified before beginning demolition activities.

\subsubsection{Site Confirmation}

Samples of various media, air monitoring data, surface swipes and radiological survey data were collected in April 2006 as part of the Site Confirmation. Refer to Section 2.1 for a description of general site confirmation activities, and to Section 2.2 for a description of sampling activities performed at each structure. Tables 2-1 and 2-2 present contaminants identified on site by building and media type.

\subsubsection{Draining Lubricants/Fluids from Equipment}

Before demolition, all equipment and piping will be drained of lubricants/fluids to the extent possible by using standard methods. The PCB hydraulic oil, crane and robotic arm oils, Freon gas and other incidental oils were drained from 5400 and 5400A in April 2006. It is not known whether 5410 currently contains any liquids. This will be verified before or during D\&D activities. All lubricants/fluids will be sampled for hazardous/radiological constituents or as required for disposal. Sample analytical results will determine whether the lubricants/fluids are to be reused, recycled, or managed and disposed of appropriately. Section 4.1 provides a discussion of how materials containing PCBs and Freon will be handled during the site closure. Freon from the 5400A HVAC and refrigerant systems in Buildings 5400 and 5400A were removed in April 2006. Table 4-1 lists source material containing PCBs or Freon and plans for its management in the final closure scenario.

\subsubsection{Hazardous and Regulated Waste Removal}

Refer to Section 2.2 for a discussion of hazardous and regulated wastes found during the Site Confirmation. Table 4-1 provides a list of source material containing hazardous or regulated waste and plans for its management in the final closure scenario. 


\subsubsection{Asbestos Containing Material}

All ACM will be removed by trained asbestos workers and disposed of properly. Removal of ACM is anticipated to be a minor effort. It is suspected that a tabletop in Building 5400A contains asbestos.

\subsubsection{Resource Conservation and Recovery Act Metals}

\subsection{Lead}

Lead components that can be readily removed (e.g., lead sheet, lead-acid batteries) will be radiologically surveyed, removed, managed, or disposed of as described in Section 6.2.5.1. The 79,000 lb lead shielding wall will remain in place for entombment in Building 5400 because the safety hazards and costs associated with removing the wall greatly outweigh any benefit from removal. Because it is present in deminimous amounts and there is no path to groundwater in the final closure scenario, lead solder in electrical components will also be entombed in Building 5400. Building 5400 interior paint found to contain lead during the Site Confirmation will remain in place because the safety hazards and costs associated with removing the paint greatly outweigh any benefit from removal. Lead-acid batteries will be removed before demolition/entombment.

\subsection{Mercury}

Items containing mercury (e.g., mercury switches, light bulbs) will be identified, removed, and disposed of as described in Section 6.2.5.1.

\subsubsection{Polychlorinated Biphenyls}

Drained fluids were sampled for radiological and PCB content. Overhead crane oils and Pydraul hydraulic system oils were removed in April 2006. Articles and/or containers containing drained fluid contaminated with PCBs will be treated as discussed in Section 6.2.5.1. Building 5400 interior paint found to contain PCBs during the Site Confirmation will remain in place because the safety hazards and costs associated with removing the paint greatly outweigh any benefit from removal. 


\subsubsection{Placement of Radiologically Impacted Items}

Site confirmation activities and completed waste inventories (see Section 2.2) indicate that radiologically impacted debris and equipment remain in Buildings 5400 and the Wooden Shed. It is expected that similar material will be found in Building 5410 after a waste inventory has been completed. Following removal of hazardous materials or mixed waste, radiologically impacted material or debris classified as LLW may be placed in Building 5400 before entombment if it is compatible (i.e., the debris is not hazardous or mixed waste, consists of the same radionuclides, and will not increase void space after entombment). Additionally, material from other NTS decontamination and decommissioning (D\&D) activities of similar nature (e.g., concrete rubble from Test Cell C, etc.) to the CAU 118 Facility may be placed in Building 5400 before entombment, as approved by NDEP on a case-by-case basis.

\subsubsection{Demolition and Disposal}

After removing equipment and regulated or hazardous materials and stabilizing or removing any radiological contamination (as appropriate or needed), Buildings 5400A and 5410 will be demolished to their concrete slabs. Heavy equipment, power tools, forklifts, loaders, trucks and other equipment will be used as needed. Debris from the demolition of these buildings will be disposed of according to the NTSWAC (NNSA/NSO, 2005) at approved NTS disposal sites. Following demolition, the concrete slabs below Buildings 5400A and 5410 will be surveyed and posted as per the NV/YMP RadCon Manual (NNSA/NSO, 2004). Steel and aluminum from building structures are considered radiologically impacted from neutron activation that took place during reactor operation. However, analytical samples confirm that radioactivity levels in the structure of Buildings 5400A are below levels specified by the NTS 10c Industrial Landfill Permit. Further data are needed to confirm conditions at Building 5410, but it is expected that radioactivity levels of the Building 5410 structure will also be below levels specified by the NTS 10c Industrial Landfill Permit. Building 5410 internal components (e.g., ventilation ducts, filters) are suspected to be radiologically contaminated and will be disposed of accordingly.

After removing equipment and regulated or hazardous materials, the Wooden Shed will be demolished to grade level, provided characterization samples show no evidence of regulated lead or asbestos within the building structure. A water spray will be applied before demolition in order to 
saturate the interior and exterior of the shed, and to control dust from demolition activities. The shed will be destructed with a minimum amount of size reduction. Current plans are for the demolition and loading to be accomplished with a loader and/or track hoe. Debris will be disposed of according to the NTSWAC (NNSA/NSO, 2005) at an approved NTS disposal site. After demolition, the area under the shed will be inspected for soil staining from spills that may have occurred within the shed. If clean, the area may be considered for run-on and run-off control.

\subsubsection{Prepare Structure for Final End-State}

Once Buildings 5400A and 5410 have been demolished to the slab, and associated debris is cleared and disposed of, preparations for and execution of the final closure actions will commence. Final end-state will be achieved through the completion of the actions/activities discussed below. The technical specification drawings containing the final closure instructions are presented in Drawings C-1 through C-7 and M-1 through M-3 in Appendix B.

- $\quad$ Building 5400A, High Bay

- Hazardous and mixed wastes (e.g., lead, mercury, ACM) will be stripped out and disposed of appropriately.

- The building structure, including the shell, HVAC and stacks, will be demolished to slab and disposed of on site (at NTS).

- The remaining concrete slab will be surveyed and posted according to the NV/YMP RadCon Manual (NNSA/NSO, 2004).

- Building 5400, Reactor Building

- All liquids, gases, and other hazardous wastes will be removed and disposed of appropriately.

- Debris from Buildings 5410 and the Wooden Shed may be placed in Building 5400 for entombment if it is determined to be compatible (i.e., the debris is not hazardous or mixed waste, consists of the same radionuclides, and will not increase void space after entombment).

- All ventilation and the hydraulic line chase connecting Buildings 5400 and 5410 will be filled with flowable grout.

- The overpressure well will be filled with flowable grout. 
- The basement, stairwell, sump, and lower portion of the reactor stand and associated systems will be filled with flowable grout.

- The reactor room and all associated debris and fixtures will be filled from a 3-ft access port in the ceiling of the reactor room (High Bay floor). The reactor stand, lead wall, and any associated activated or contaminated solid media (e.g., tools, equipment, electronics, test canisters) will be left in the room and filled in place. See Appendix C and Appendix D for qualitative and quantitative discussions, respectively, on the justification for leaving lead in place. All void spaces within the structure will be filled.

- The access tunnel to Building 5400 and all associated debris and fixtures from the reactor room will be filled to the tunnel entrance. The entrance to the tunnel will be sealed closed.

- Engineering specifications to prevent weathering and precipitation infiltration (i.e., grade surrounding the area to ensure surface water flows away from buildings) will be implemented.

- Building 5410, Mechanical Building

- Contents will be stripped out and either disposed of or placed in Building 5400 for entombment, as appropriate.

- The structure will be demolished to slab. Structure material will be disposed of appropriately.

- The remaining concrete slab will be surveyed and posted according to the NV/YMP RadCon Manual (NNSA/NSO, 2004).

- Wooden Shed

- Contents will be stripped out and either disposed of or placed in Building 5400 for entombment, as appropriate.

- The structure will be demolished to grade. Structure material will be disposed of appropriately.

- It will be verified that no contamination exists in soil underneath the shed. Soils will either be less than the FALs or included in the Use Restriction.

- Ancillary Structures

- It is proposed that concrete stairs and railings, perimeter fencing, bollards, and turnstiles will be removed.

The NDEP will be consulted on the extent of controls to be implemented before final closure. 


\subsection{Verification}

Table 5-8 of the CAU 118 FI summarizes the sampling approach used to achieve closure objectives for CAS 27-41-01, CAU 118 (SNJV, 2006). The analytical data collected from this sampling approach will be used to place Use Restriction boundaries around the CAU.

Radiological surveys for total and removable contamination are required to verify that the concrete foundations remaining from Buildings 5400A and 5410 are not contaminated. No additional analytical data or analysis is required to verify that the remaining concrete surfaces have been decontaminated to acceptable levels to achieve closure.

Any soil contamination surrounding Building 5400 is expected to come from activation products. Soil data taken during the Site Confirmation indicated that no activation of soils surrounding Building 5400 had occurred. Initial site inspections indicate that chemical COCs have not impacted the foundation of Building 5400A. Because no post-demolition remediation is planned for chemical COCs, verification samples will not be required.

If before demolition activities any COCs are detected in samples collected from floor stains, spill areas, and similar items from Building 5410 and the Wooden Shed, further characterization will be performed in order to apply the appropriate Use Restrictions. Soil samples adjacent to Building 5410 and underneath the Wooden Shed will be taken after demolition to characterize the extent of COC contamination.

\subsubsection{Radiological Surveys}

Methods used to conduct surveys are outlined in project documents such as the FWP, FI and Radiological Work Permit (RWP). These methods are sufficient to demonstrate compliance with the SNJV Radiation Protection Program, NV/YMP RadCon Manual (NNSA/NSO, 2004), and 10 Code of Federal Regulations (CFR) 835, “Occupational Radiation Protection” (CFR, 2003a).

Radiation survey instruments are maintained under the direction of SNJV Radiological Instrumentation and Calibration procedure, Technical Basis Document "Portable Radiation Survey Instrumentation” and Manufacture Technical Manuals to meet the requirements of 10 CFR 835.401, 
“Occupational Radiation Protection, Monitoring of Individuals and Areas, General Requirements” (CFR, 2003a).

\subsubsection{Initial Characterization Surveys}

Instruments and methods used to conduct radiological surveys during the Site Confirmation are outlined in Appendix B of the project FI.

\subsubsection{Post-Demolition Surveys}

Instrumentation and methods used to conduct post-demolition surveys to determine the final status of the concrete slabs for Buildings 5400A and 5410 will be performed as per project documents such as the FWP, FI, and RWP. These documents may be amended to reflect new hold points or special conditions arising during the final closure process.

\subsection{Closure}

Specific activities required to close CAU 118 are described in Section 4.2 and in the Technical Specifications provided in Appendix B. Hold points and special conditions that may be outside the initial project assumptions of this SAFER plan may impact the requirements for closure. General closure activities include:

- $\quad$ Site Preparation (completed)

- $\quad$ Site Confirmation (partially completed)

- DQO/SAFER Process

- Hazard Reduction/Waste Management

- Demolition, Disposal and Final Investigation

- $\quad$ Prepare Structure for Final End-State

- Project closeout including preparation and submittal of a Closure Report to the NNSA and NDEP for approval. 
Upon approval of the Closure Report from NDEP, the NNSA/NSO will request that CAU 118 be promoted to Appendix IV of the FFACO, "Closed Corrective Action Units."

\subsection{Duration}

The following is a tentative duration of activities (in calendar days) for SAFER activities:

\begin{tabular}{|c|c|}
\hline Duration (days) & Activity \\
\hline \hline 7 & Remove Hazardous Materials and Wooden Shed \\
\hline 50 & $\begin{array}{c}\text { 5400A \& 5410 Structure Demolition and Waste } \\
\text { Management }\end{array}$ \\
\hline 7 & $\begin{array}{c}\text { Prepare and Fill Ventilation Systems, OP Well } \\
\text { and Utility Chases }\end{array}$ \\
\hline 21 & Fill 5400 with Flowable Grout \\
\hline 5 & Remove Fencing, Exterior Stairs, Bollards \\
\hline 10 & Construct Engineering Controls to Cover/Protect \\
\hline
\end{tabular}




\subsection{Reports and Records Availability}

Historic information and documents referenced in this plan are retained in the NNSA/NSO project files in Las Vegas, Nevada, and can be obtained through written request to the NNSA/NSO Project Manager. This document is available in the DOE public reading rooms located in Las Vegas and Carson City, Nevada, or by contacting the appropriate DOE project manager. The NDEP maintains the official Administrative Record for all activities conducted under the auspices of the FFACO. 


\subsection{Investigation/Remediation Waste Management}

Management of IDW and D\&D wastes will be based on regulatory requirements, field observations, process knowledge, and laboratory results from CAU 118 investigation samples.

Disposable sampling equipment, personal protective equipment (PPE), and rinsate are considered potentially contaminated waste only by virtue of contact with potentially contaminated media (e.g., soil) or potentially contaminated debris (e.g., construction materials). Therefore, sampling and analysis of IDW, separate from analyses of site investigation samples, may not be necessary for all IDW. However, if associated investigation samples are found to contain contaminants above regulatory levels, conservative estimates of total waste contaminant concentrations may be made based on the mass of the waste, the amount of contaminated media contained in the waste, and the maximum concentration of contamination found in the media. Direct samples of IDW may also be taken to support waste characterization.

Sanitary, hazardous, radioactive, and/or mixed waste, if generated, will be managed and disposed of in accordance with applicable DOE orders, U.S. Department of Transportation (DOT) regulations, state and federal waste regulations, and agreements and permits between DOE and NDEP. Materials left in place are not considered to be generated and are not subject to RCRA or the requirements of the section below.

\subsection{Waste Minimization}

Investigation activities are planned to minimize IDW generation. This will be accomplished by incorporating the use of process knowledge, visual examination, and/or radiological survey and swipe results. When possible, disturbed media (such as soil removed during trenching) or debris will be returned to its original location. Contained media (e.g., soil managed as waste) as well as other IDW will be segregated to the greatest extent possible to minimize generation of hazardous, radioactive, or mixed waste. Hazardous material used at the sites will be controlled in order to limit unnecessary generation of hazardous or mixed waste. Administrative controls, including decontamination procedures and waste characterization strategies, will minimize waste generated during investigations. 
Compatible (refer to Section 3.1.7.1.2) debris found in Buildings 5400A, 5410, and the Wooden Shed will be placed in Building 5400 before entombment. It is anticipated that the majority of debris generated from the demolition of Buildings 5400A, 5410, and the Wooden Shed will qualify for disposal as sanitary waste. However, items from this debris found to be radiologically or chemically impacted above the limits for the Industrial Landfill will be managed in accordance with Section 6.2.2.

\subsection{Potential Waste Streams}

Site sampling was conducted in April 2006 for purposes of site confirmation, quality control, and waste characterization. Project waste could include solid, liquid, gases, and potentially sludge wastes. Waste generated from the sampling effort consisted of polychlorinated biphenyl (PCB) waste, mixed PCB/LLW, and potentially both LLW and MLLW. Waste generated during the corrective action activities will include the following potential waste streams:

- Sanitary wastes

- LLW

- MLLW

- Hazardous waste

- $\quad$ TSCA waste: PCB waste/LLW, ACM

For commonly disposed items, such as fluorescent and incandescent light bulbs, process knowledge may be used for waste designation/disposal. No sampling for hazardous waste constituents (such as RCRA constituents) is required, although radiological surveys may be required to determine whether the waste meets the regulatory requirements for LLW (SNJV, 2006).

The on-site management and ultimate disposition of wastes will be determined based on a determination of the waste type (e.g., sanitary, low-level, hazardous, hydrocarbon, mixed), or the combination of waste types. A determination of the waste type will be guided by several factors, including, but not limited to: the analytical results of samples either directly or indirectly associated with the waste, historical site knowledge, knowledge of the waste generation process, field observations, field-monitoring/screening results, and/or radiological survey/swipe results.

Table 4-2 of the NV/YMP RadCon Manual (NNSA/NSO, 2004) shall be used to determine whether such materials may be declared nonradioactive. On-site IDW management requirements by waste 
type are detailed in the following sections. Applicable waste management regulations and requirements are listed in Table 6-1.

Table 6-1

\section{Waste Management Regulations and Requirements}

\begin{tabular}{|c|c|c|}
\hline Waste Type & Federal Regulation & Additional Requirements \\
\hline Solid (nonhazardous) & $\mathrm{N} / \mathrm{A}$ & $\begin{array}{c}\text { NRS }^{a} 444.440-444.620 \\
\text { NAC }^{b} 444.570-444.7499 \\
\text { NTS Landfill Permit SW13.097.04 } \\
\text { NTS Landfill Permit SW13.097.03 }\end{array}$ \\
\hline Liquid/Rinsate (nonhazardous) & N/A & $\begin{array}{l}\text { Water Pollution Control General Permit } \\
\text { GNEV93001, Rev. 3iii }\end{array}$ \\
\hline Hazardous & $\begin{array}{c}\text { RCRA }^{f}, \\
40 \text { CFR 260-282 }\end{array}$ & $\begin{array}{c}\text { NRS }^{\mathrm{a}} 459.400-459.600 \\
\text { NAC }^{\mathrm{b}} 444.850-444.8746 \\
\mathrm{POC}^{\mathrm{g}}\end{array}$ \\
\hline Low-Level Radioactive & N/A & DOE Orders and NTSWAC ${ }^{h}$ \\
\hline Mixed & $\begin{array}{c}\text { RCRA }^{f}, \\
40 \text { CFR 260-282 }\end{array}$ & $\begin{array}{l}\text { NTSWAC } \\
\text { POC }^{\mathrm{h}}\end{array}$ \\
\hline Hydrocarbon & $\mathrm{N} / \mathrm{A}$ & NTS Landfill Permit SW13.097.02i \\
\hline Polychlorinated Biphenyls & $\begin{array}{l}\text { TSCA }^{\mathrm{j}} \\
40 \text { CFR } 761\end{array}$ & $\begin{array}{l}N_{R S}^{a} 459.400-459.600 \\
N^{a} C^{b} 444.940-444.9555\end{array}$ \\
\hline Asbestos & $\begin{array}{c}\text { TSCA }^{\mathrm{j}} \\
40 \text { CFR } 763\end{array}$ & $\begin{array}{l}N_{R S^{a}} 618.750-618.840 \\
N^{b} C^{b} 444.965-444.976\end{array}$ \\
\hline
\end{tabular}

${ }^{a}$ Nevada Revised Statutes (NRS, 2005a, b, c)

${ }^{\mathrm{b}}$ Nevada Administrative Code (NAC, 2005)

${ }^{\text {c} A r e a ~} 23$ Class II Solid Waste Disposal Site (NDEP, 1997a)

${ }^{\mathrm{d} A r e a} 9$ Class III Solid Waste Disposal Site (NDEP, 1997c)

${ }^{\mathrm{e}}$ Nevada Test Site Sewage Lagoons (NDEP, 1999)

${ }^{\mathrm{f}}$ Resource Conservation and Recovery Act (CFR, 2003b)

${ }^{9}$ Nevada Test Site Performance Objective for the Certification of Nonradioactive Hazardous Waste (BN, 1995)

${ }^{\mathrm{h}}$ Nevada Test Site Waste Acceptance Criteria, Rev. 6 (NNSA/NSO, 2005)

'Area 6 Class III Solid Waste Disposal Site for hydrocarbon waste (NDEP, 1997b)

${ }^{\mathrm{j}}$ Toxic Substance Control Act (CFR, 2003c and d)

CFR $=$ Code of Federal Regulations

DOE $=$ U.S. Department of Energy

$\mathrm{N} / \mathrm{A}=$ Not applicable

NAC $=$ Nevada Administrative Code

NDEP $=$ Nevada Division of Environmental Protection

NRS = Nevada Revised Statutes

NTS = Nevada Test Site

NTSWAC = Nevada Test Site Waste Acceptance Criteria

$\mathrm{POC}=$ Performance Objective for the Certification of Nonradioactive Hazardous Waste

RCRA = Resource Conservation and Recovery Act

TSCA $=$ Toxic Substance Control Act 


\subsubsection{Sanitary Waste}

Non-hazardous, solid waste items (e.g., debris from demolished structures, piping, and/or scrap metal) that have been surveyed by RadCon and determined not to be radiologically impacted above the surface and mass concentrations for the NTS 10c Industrial Landfill may qualify for disposal as sanitary waste. Sanitary IDW generated will be collected, managed, and disposed of according to the sanitary waste management regulations and the permits for operation of the NTS 10c Industrial Waste Landfill.

\subsubsection{Low-Level Waste}

Low-level waste generated at CAU 118 will be packaged and managed in accordance with all applicable federal, state and NTS requirements. Low-level waste is defined as any radioactive waste not classified as transuranic waste, high-level waste, or spent nuclear fuel. Low-level waste may be generated as a result of operations in areas where radioactive materials are or were formerly managed. Low-level waste forms expected include debris, tools and equipment, combustibles, light metals, and liquids (SNJV, 2006). As part of the closure strategy for CAU 118, most solid low-level waste generated or found on site will be placed in Building 5400 before entombment.

Non-hazardous solid waste that exceeds the permissible radiological surface and mass concentration for the NTS 10c Industrial Landfill Permit will be managed as LLW. Radiological swipe surveys and/or direct-scan surveys may be conducted on reusable sampling equipment and the PPE and disposable sampling equipment waste streams exiting a radiologically controlled area (RCA). This allows for the immediate segregation of radioactive waste from waste that may be unrestricted regarding radiological release. Removable contamination limits, as defined in Table 4-2 of the current version of the NV/YMP RadCon Manual (NNSA/NSO, 2004), will be used to determine whether such waste may be declared unrestricted regarding radiological release versus being declared radioactive waste. Direct sampling of the waste may be conducted to aid in determining whether a particular waste unit (e.g., drum of soil) contains LLW, as necessary. Waste that is determined to be below the values of Table 4-2, by either direct radiological survey/swipe results or through process knowledge, will not be managed as potential radioactive waste but will be managed in accordance with the appropriate section of this document. Wastes in excess of Table 4-2 values will be managed 
as potential radioactive waste and be managed in accordance with this section and any other applicable sections of this document.

The LLW, if generated, will be managed in accordance with the contractor-specific waste certification program plan, DOE orders, and the requirements of the current version of the NTSWAC (NNSA/NSO, 2005). Potential radioactive waste containing soil, PPE, disposable sampling equipment, and/or rinsate may be staged at a designated radioactive material area (RMA) or RCA when full or at the end of an investigation phase. The waste drums will remain at the RMA pending certification and disposal under NTSWAC requirements (NNSA/NSO, 2005).

\subsubsection{Mixed Low-Level Waste}

Mixed waste is waste containing both RCRA hazardous and LLW characteristics. These wastes will be managed in accordance with the applicable radioactive waste and hazardous waste requirements. If generated, solid MLLW will be stored, treated, and disposed at an approved MLLW facility. If liquid MLLW is generated, it will be packaged for treatment/disposal at a DOE-approved site (SNJV, 2006). The MLLW found on site is mostly likely generated by hazardous material impacted by neutron activation products generated during operation of the reactor.

Mixed low-level waste, if generated, shall be managed and dispositioned according to the requirements of RCRA (CFR, 2003b) or subject to agreements between NNSA/NSO and the State of Nevada, as well as DOE requirements for radioactive waste. The waste will be marked with the words “Hazardous Waste Pending Analysis and Radioactive Waste Pending Analysis.” Waste characterized as mixed will not be stored for a period of time that exceeds the requirements of RCRA unless subject to agreements between NNSA/NSO and the State of Nevada. The MLLW shall be transported via an approved hazardous waste/radioactive waste transporter to the NTS transuranic waste storage pad for storage pending treatment or disposal. Mixed low-level waste with hazardous waste constituent concentrations below Land Disposal Restrictions may be disposed of at the NTS Area 5 Radioactive Waste Management Site if the waste meets the requirements of the NTSWAC (NNSA/NSO, 2005), the NDEP NTS permit for a Hazardous Waste Management Facility (NEV HW0009 [NDEP, 2000]), and the RCRA Part B Permit Application for Waste Management Activities at the Nevada Test Site (DOE/NV, 1999). Hazardous waste constituent concentrations (within MLLW) exceeding Land Disposal Restrictions will require development of a treatment and disposal 
plan under the requirements of the Mutual Consent Agreement between DOE and the State of Nevada (NDEP, 1995).

\subsubsection{Hazardous Waste}

The RCRA waste contains hazardous constituents or exhibits hazardous characteristics as defined by RCRA and the State of Nevada Hazardous Waste Regulations (see Table 6-1). A variety of hazardous wastes may be generated, including metals, organics, combustibles, and hazardous liquids. Items with the potential of being RCRA-regulated hazardous waste were identified during the site confirmation phase in early 2006. These items include mercury-vapor lamps, mercury switches, lead-acid batteries, lead ballast, lead solder, and similar items. The RCRA waste is routinely shipped to off-site commercial facilities for treatment and/or disposal. Hazardous materials will be removed before building demolition begins.

The CAU will have waste accumulation areas established according to the needs of the project. Satellite accumulation areas and hazardous waste accumulation areas (HWAAs) will be managed consistent with the requirements of federal and state regulations. (CFR, 2003b; NAC, 2005a). The HWAAs will be properly controlled for access, and will be equipped with spill kits and appropriate spill containment. Suspected hazardous wastes will be placed in DOT-compliant containers. All containerized hazardous waste will be handled, inspected, and managed in accordance with Title 40 CFR 265 Subpart I (CFR, 2003b). These provisions include managing the waste in containers compatible with the waste type, and segregating incompatible waste types so that in the event of a spill, leak, or release, incompatible wastes shall not contact one another. The HWAAs will be covered under a site-specific emergency response and contingency action plan until such time that the waste is determined to be nonhazardous or all containers of hazardous waste have been removed from the storage area. Hazardous waste will be characterized in accordance with the requirement of Title 40 CFR 261. Any waste determined to be hazardous will be managed and transported in accordance with RCRA and DOT requirements to a permitted treatment, storage, and disposal facility (CFR, 2003b).

\subsubsection{TSCA Waste}

The TSCA waste consists of either PCB waste (solid or liquid) and asbestos. 


\subsubsection{Polychlorinated Biphenyls}

The management of PCBs is governed by the Toxic Substances Control Act (TSCA) (USC, 1976) and its implementing regulations at 40 CFR 761 (CFR, 2003c). Polychlorinated biphenyl contamination may be found as a sole contaminant or in combination with any of the types of waste discussed in this document. For example, PCBs may be a co-contaminant in soil that contains a RCRA "characteristic" waste (PCB/hazardous waste), or in soil that contains radioactive wastes ( $\mathrm{PCB} /$ radioactive waste), or even in mixed waste (PCB/radioactive/hazardous waste). The IDW will initially be evaluated using analytical results for media samples from the investigation. If any type of PCB waste is generated, it will be managed according to 40 CFR 761 (CFR, 2003c) as well as State of Nevada requirements, (NAC, 2004) guidance, and agreements with NNSA/NSO.

During the site confirmation phase, PCBs were identified in equipment oils and building paint samples. Hydraulic oils containing PCBs will be managed as PCB liquids. Polychlorinated biphenyl waste will be packaged and managed in accordance with all applicable regulations pending shipment to an off-site treatment and/or disposal facility. The PCB waste from CAU 118 has been identified as potentially radioactive (LLW). Because of the regulatory requirements associated with waste containing TSCA and LLW characteristics, the disposal path has been identified as an incinerator in Oak Ridge, Tennessee, that is permitted to accept TSCA/LLW waste (SNJV, 2006).

\subsubsection{Asbestos-Containing Material}

Asbestos-containing material may be found in CAU 118. Based on site walkdowns, it is suspected that a blanket in a cabinet of the 5400 access tunnel may be asbestos, and that a desktop in 5400A contains non-friable asbestos (SNJV, 2006). Samples of suspected ACM in Building 5400A were collected an analyzed in April 2006. Results confirmed that ducting insulation and insulation panels in Building 5400A do not contain ACM. Disposal options for ACM may vary depending on other contaminants present in the waste. All ACM to be removed will be removed by trained asbestos workers and disposed of in the Industrial Waste Facility or LLW Waste Facility in accordance with the NTSWAC. 


\subsection{Management of Specific Waste Streams}

\subsubsection{Freon}

Freon was identified during the site confirmation phase in an HVAC system located on the exterior of Building 5400A, in a refrigerant system inside Building 5400A, and in a refrigerant system inside Building 5400. These systems were evacuated in April 2006. All fluids were drained, containerized, managed, and will be recycled or disposed of according to the appropriate regulations.

\subsubsection{Decontamination Rinsate}

Potentially contaminated rinsate will be segregated from "clean" rinsate that may be generated during pre-use decontamination activities for equipment, as applicable. Rinsate generated during sampling activities will be characterized based on analytical results of associated samples. Additional samples may be collected directly from the rinsate, if needed, for waste characterization purposes. Pre-use surveys of equipment may assist in minimizing rinsate generated (SNJV, 2006).

\subsubsection{Personal Protective Equipment}

Personal protective equipment and disposable sampling equipment will be visually inspected for stains, discoloration, and gross contamination as the waste is generated, and also evaluated for radiological contamination. Staining and/discoloration will be assumed to be the result of contact with potentially contaminated media such as soil, sludge, or liquid. Gross contamination is the visible contamination of an item (e.g., clumps of soil/sludge on a sampling spoon or free liquid smeared on a glove). While gross contamination can often be removed through decontamination methods, removal of gross contamination from small items, such as gloves or booties is not typically conducted. Any IDW that meets this description will be segregated and managed as potentially "characteristic" hazardous waste. This segregated population of waste will either: (1) be assigned the characterization of the soil/sludge that was sampled, (2) be sampled directly, or (3) undergo further evaluation using the soil/sludge sample results to determine how much soil/sludge would need to be present in the waste to exceed regulatory levels. Waste that is determined to be hazardous will be entered into an approved waste management system, where it will be managed and dispositioned according to RCRA requirements or subject to agreements between NNSA/NSO and the State of 
Nevada. The PPE and equipment that is not visibly stained, discolored, or grossly contaminated and that is within the radiological free-release criteria will be managed as nonhazardous sanitary waste.

\subsubsection{Soil and Debris}

This waste stream can vary depending on site conditions. Debris that requires removal for the investigation activities (soil sampling, excavation, and/or drilling) must be characterized for proper management and disposition. Historical site knowledge, knowledge of the waste generation process, field observations, field-monitoring/screening results, radiological survey/swipe results and/or the analytical results of samples either directly or indirectly associated with the waste may be used to characterized the debris. Debris will be visually inspected for stains, discoloration, and gross contamination. Debris may be deemed reusable, recyclable, sanitary waste, hazardous waste, PCB waste, or LLW. Waste that is not sanitary will be entered into an approved waste management system, where it will be managed and dispositioned according to federal, state requirements, and agreements between NNSA/NSO and the State of Nevada. The debris will either be managed on site by berming and covering next to the excavation, by placement in a container(s), or left on the footprint of the CAS and its disposition deferred until implementation of corrective action at the site.

Waste is characterized based on process knowledge and associated media samples. It is assumed that the majority of debris and/or soil can be returned to the original sample location. If soil cannot be return to the original location, it may be placed in a container, managed as waste, and characterized based on soil sample results (SNJV, 2006). Loose and miscellaneous debris (e.g., equipment, parts, trash) that is unattached to the structure will be inventoried and characterized. It is anticipated that sampling of debris may occur on a case-specific basis, as needed. The primary method of characterizing the debris will consist of a visual inspection, direct radiological measurement, smears for removable contamination, and sampling, as appropriate (SNJV, 2006).

\subsubsection{Field-Screening Waste}

The use of field test kits and/or instruments may result in the generation of small quantities of hazardous wastes. If hazardous waste is produced by field screening, it will be segregated from other IDW and managed in accordance with the hazardous waste regulations (CFR, 2003b). For sites where field-screening samples contain radioactivity above background levels, field-screening 
CAU 118 SAFER Plan

Section: 6.0

Revision: 1

Date: September 2006

Page 84 of 98

methods that have the potential to generate hazardous waste will not be used, thus avoiding the potential to generate MLLW. In the event MLLW is generated, the waste will be managed in accordance with Section 6.2 .3 of this document. 


\subsection{Quality Assurance/Quality Control}

The overall objective of the characterization activities described in this SAFER plan is to collect accurate and defensible data to support the selection and implementation of a closure alternative for CAS 27-41-01 in CAU 118. Sections 7.1 and 7.2 discuss the collection of required QC samples in the field and QA requirements for laboratory/analytical data to achieve closure. With the exception of oil samples, QC samples will be collected according to SBMS procedure "Collection of Field Quality Control Samples” and the Industrial Sites QAPP (NNSA/NV, 2002a). The QA/QC methods discussed in this section are only applicable to soil samples.

\subsection{Sample Collection Activities}

Soil requiring additional characterization will be sampled and analyzed according to the Sampling and Analysis Plan (SAP) for CAU 118. At a minimum, the SAP will address the following:

- $\quad$ Sampling plan objectives

- DQO: Confidence levels, precision, accuracy, representativeness, comparability, and completeness

- Number and location of regular and QC samples

- Sampling technique

- $\quad$ Sampling equipment

- Field decontamination of sampling equipment

- Field observations and notebook

Field QC samples will be collected in accordance with established procedures. Field QC samples are collected and analyzed to aid in determining the validity of environmental sample results. The number of required QC samples depends on the types and number of environmental samples collected. The minimum frequency of collecting and analyzing QC samples for this investigation, as determined in the DQO process, include:

- $\quad$ Trip blanks (one per sample cooler containing VOC environmental samples)

- Equipment rinsate blanks (one per sampling event for each media by characterization unit)

- $\quad$ Source blanks (one per lot of source material that contacts sampled media) 
- Field duplicates (one per 20 environmental samples or one per CAS per matrix, if less than 20 collected)

- Field blanks (one per CAS or one per day if environmental conditions change)

- Laboratory QC samples (one per 20 environmental samples or one per CAS, if less than 20 collected, not required for all radionuclide measurements)

Additional QC samples may be submitted based on site conditions at the discretion of the Task Manager or Site Supervisor. Field QC samples shall be analyzed using the same analytical procedures implemented for associated environmental samples. Additional details regarding field QC samples are available in the Industrial Sites QAPP (NNSA/NV, 2002a).

\subsection{Applicable Laboratory/Analytical Data Quality Indicators}

Confirmation of achieving site closure objectives shall be provided primarily by radiological surveys, as discussed in Section 4.3.1.2, "Post Demolition Surveys." However, laboratory analysis was required during the site confirmation phase and for waste characterization samples. All laboratory data from waste characterization samples will be evaluated for data quality. The DQIs are qualitative and quantitative descriptors used in interpreting the degree of acceptability or utility of data. Data quality indicators are used to evaluate the entire measurement system and laboratory measurement processes (i.e., analytical method performance) as well as to evaluate individual analytical results (i.e., parameter performance). The quality and usability of data used to make DQO decisions will be assessed based on the following DQIs:

- Precision

- Accuracy/bias

- Representativeness

- Comparability

- Completeness

- Sensitivity

Table 7-1 provides the established analytical method/measurement system performance criteria for each of the DQIs and the potential impacts to the decision if the criteria are not met. The following subsections discuss each of the DQIs that will be used to assess the quality of laboratory data. Due to changes in analytical methodology and changes in analytical laboratory contracts, criteria for 
Table 7-1

Laboratory and Analytical Performance Criteria for CAU 118 Data Quality Indicators

\begin{tabular}{|c|c|c|}
\hline $\begin{array}{l}\text { Data Quality } \\
\text { Indicator }\end{array}$ & Performance Metric & $\begin{array}{l}\text { Potential Impact on Decision } \\
\text { If Performance Metric Not Met }\end{array}$ \\
\hline Precision & $\begin{array}{l}\text { At least } 80 \% \text { of the sample results for each } \\
\text { measured contaminant are not qualified for } \\
\text { precision based on the criteria for each analytical } \\
\text { method-specific and laboratory-specific criteria } \\
\text { presented in Tables 3-6 and 3-7, or for the field } \\
\text { duplicate criteria of } 80 \% \text { RPD or } 2 \% \text { ND. }\end{array}$ & $\begin{array}{l}\text { If the performance metric is not met, the } \\
\text { affected analytical results from each } \\
\text { affected CAS will be assessed to determine } \\
\text { whether there is sufficient confidence in } \\
\text { analytical results to use the data in making } \\
\text { DQO decisions. }\end{array}$ \\
\hline Accuracy & $\begin{array}{l}\text { At least } 80 \% \text { of the sample results for each } \\
\text { measured contaminant are not qualified for } \\
\text { accuracy based on the method-specific and } \\
\text { laboratory-specific criteria presented in } \\
\text { Tables 3-6 and 3-7. }\end{array}$ & $\begin{array}{l}\text { If the performance metric is not met, the } \\
\text { affected analytical results from each } \\
\text { affected CAS will be assessed to determine } \\
\text { whether there is sufficient confidence in } \\
\text { analytical results to use the data in making } \\
\text { DQO decisions. }\end{array}$ \\
\hline Sensitivity & $\begin{array}{l}\text { Minimum detectable concentrations are less than } \\
\text { or equal to respective FALs. }\end{array}$ & $\begin{array}{l}\text { Cannot determine whether COCs are } \\
\text { present or migrating at levels of concern. }\end{array}$ \\
\hline Comparability & $\begin{array}{l}\text { Sampling, handling, preparation, analysis, } \\
\text { reporting, and data validation are performed } \\
\text { using standard methods and procedures. }\end{array}$ & $\begin{array}{l}\text { Inability to combine data with data obtained } \\
\text { from other sources and/or inability to } \\
\text { compare data to regulatory action levels. }\end{array}$ \\
\hline Representativeness & $\begin{array}{l}\text { Samples contain contaminants at concentrations } \\
\text { present in the environmental media from which } \\
\text { they were collected. }\end{array}$ & $\begin{array}{l}\text { Analytical results will not represent true site } \\
\text { conditions. Inability to make appropriate } \\
\text { DQO decisions. }\end{array}$ \\
\hline Completeness & $\begin{array}{l}80 \% \text { of the CAS-specific COPCs have valid } \\
\text { results. } \\
100 \% \text { of CAS-specific targeted contaminants } \\
\text { have valid results. }\end{array}$ & $\begin{array}{l}\text { Cannot support/defend decision on whether } \\
\text { COCs are present. }\end{array}$ \\
\hline Extent Completeness & $\begin{array}{l}100 \% \text { of COCs used to define extent have valid } \\
\text { results. }\end{array}$ & $\begin{array}{l}\text { Extent of contamination cannot be } \\
\text { accurately determined. }\end{array}$ \\
\hline $\begin{array}{l}\text { Clean Closure } \\
\text { Completeness }\end{array}$ & $\begin{array}{l}100 \% \text { of targeted contaminants have valid } \\
\text { results. }\end{array}$ & $\begin{array}{l}\text { Cannot determine whether COCs remain in } \\
\text { soil. }\end{array}$ \\
\hline
\end{tabular}

CAS = Corrective action site

$\mathrm{COC}=$ Contaminant of concern

$\mathrm{COPC}=$ Contaminant of potential concern

$\mathrm{DQO}=$ Data quality objective

$\mathrm{FAL}=$ Final action level

ND $=$ Normalized difference

RPD = Relative percent difference

precision and accuracy in Tables 3-6 and 3-7 that vary from corresponding information in the QAPP will supersede that information in the QAPP (NNSA/NV, 2002a). 


\subsubsection{Precision}

Precision is a measure of the repeatability of the analysis process from sample collection through analysis results. It is used to assess the variability between two equal samples.

Determinations of precision will be made for field duplicate samples and laboratory duplicate samples. Field duplicate samples will be collected simultaneously with samples from the same source under similar conditions in separate containers. The duplicate sample will be treated independently of the original sample in order to assess field impacts and laboratory performance on precision through a comparison of results. Laboratory precision is evaluated as part of the required laboratory internal QC program to assess performance of analytical procedures. The laboratory sample duplicates are an aliquot, or subset, of a field sample generated in the laboratory. They are not a separate sample but a split, or portion, of an existing sample. Typically, laboratory duplicate QC samples may include matrix spike duplicate (MSD) and laboratory control sample duplicate (LCSD) samples for organic, inorganic, and radiological analyses.

Precision is a quantitative measure used to assess overall analytical method and field-sampling performance as well as to assess the need to "flag" (qualify) individual parameter results when corresponding QC sample results are not within established control limits.

The criteria used for the assessment of chemical precision when both results are greater than or equal to $5 \mathrm{x}$ reporting limit (RL) is 20 percent and 35 percent for aqueous and soil samples, respectively. When either result is less than $5 x$ RL, a control limit of $\pm 1 x$ RL and $\pm 2 x$ RL for aqueous and soil samples, respectively, is applied to the absolute difference.

The criteria used for the assessment of radiological precision when both results are greater than or equal to $5 \mathrm{x}$ MDC is 20 percent and 35 percent for aqueous and soil samples, respectively. When either result is less than $5 x$ MDC, the normalized difference (ND) should be between -2 and +2 for aqueous and soil samples. The parameters to be used for assessment of precision for duplicates are listed in Table 3-7.

Any values outside the specified criteria do not necessarily result in the qualification of analytical data. It is only one factor in making an overall judgment about the quality of the reported analytical results. The performance metric for assessing the DQI of precision on DQO decisions (see Table 7-1) 
is that at least 80 percent of sample results for each measured contaminant are not qualified due to duplicates exceeding the criteria. If this performance is not met, an assessment will be conducted in the investigation report on the impacts to DQO decisions specific to affected contaminants and CASs.

\subsubsection{Accuracy}

Accuracy is a measure of the closeness of an individual measurement to the true value. It is used to assess the performance of laboratory measurement processes.

Accuracy is determined by analyzing a reference material of known parameter concentration or by reanalyzing a sample to which a material of known concentration or amount of parameter has been added (spiked). Accuracy will be evaluated based on results from three types of spiked samples: matrix spike (MS), laboratory control sample (LCS), and surrogates (organics). The LCS sample is analyzed with the field samples using the same sample preparation, reagents, and analytical methods employed for the samples. One LCS will be prepared with each batch of samples for analysis by a specific measurement.

The criteria used for the assessment of inorganic chemical accuracy are 75 to 125 percent for MS recoveries and 80 to 120 percent for LCS recoveries. For organic chemical accuracy, MS and LCS laboratory-specific percent recovery criteria developed and generated in-house by the laboratory according to approved laboratory procedures are applied. The criteria used for the assessment of radiochemical accuracy are 80 to 120 percent for LCS and MS recoveries.

Any values outside the specified criteria do not necessarily result in the qualification of analytical data. It is only one factor in making an overall judgment about the quality of the reported analytical results. Factors beyond laboratory control, such as sample matrix effects, can cause the measured values to be outside of the established criteria. Therefore, the entire sampling and analytical process may be evaluated when determining the usability of the affected data.

The performance metric for assessing the DQI of accuracy on DQO decisions (see Table 7-1) is that at least 80 percent of the sample results for each measured contaminant are not qualified for accuracy. If this performance is not met, an assessment will be conducted in the investigation report on the impacts to DQO decisions specific to affected contaminants and CASs. 


\subsubsection{Representativeness}

Representativeness is the degree to which sample characteristics accurately and precisely represent characteristics of a population or an environmental condition (EPA, 1987). Representativeness is assured by carefully developing the sampling strategy during the DQO process such that false negative and false positive decision errors are minimized. The criteria listed in DQO Step 6 - Specify the Tolerable Limits on Decision Errors are:

- For Decision I judgmental sampling, having a high degree of confidence that the sample locations selected will identify COCs if present anywhere within the CAS.

- Having a high degree of confidence that analyses conducted will be sufficient to detect any COCs present in the samples.

- For Decision II, having a high degree of confidence that the sample locations selected will identify the extent of COCs.

These are qualitative measures that will be used to assess measurement system performance for representativeness. The assessment of this qualitative criterion will be presented in the investigation report.

\subsubsection{Completeness}

Completeness is defined as generating sufficient data of the appropriate quality to satisfy the data needs identified in the DQOs. For judgmental sampling, completeness will be evaluated using both a quantitative measure and a qualitative assessment. The quantitative measurement to be used to evaluate completeness is presented in Table 7-1 and is based on the percentage of measurements made that are judged to be valid. For the judgmental sampling approach, the completeness goal for targeted contaminants and the remaining COPCs is 100 and 80 percent, respectively. If this goal is not achieved, the dataset will be assessed for potential impacts on making DQO decisions.

The qualitative assessment of completeness is an evaluation of the sufficiency of information available to make DQO decisions. This assessment will be based on meeting the data needs identified in the DQOs and will be presented in the investigation report. Additional samples will be collected if it is determined that the number of samples do not meet completeness criteria. 


\subsubsection{Comparability}

Comparability is a qualitative parameter expressing the confidence with which one dataset can be compared to another (EPA, 1987). The criteria for the evaluation of comparability will be that all sampling, handling, preparation, analysis, reporting, and data validation were performed using approved standard methods and procedures. This will ensure that data from this project can be compared to regulatory action levels that were developed based on data generated using the same or comparable methods and procedures. An evaluation of comparability will be presented in the investigation report.

\subsubsection{Sensitivity}

Sensitivity is the capability of a method or instrument to discriminate between measurement responses representing different levels of the variable of interest (EPA, 2001). The evaluation criteria for this parameter will be that measurement sensitivity (detection limits) will be less than or equal to the corresponding FALs. If this criterion is not achieved, the affected data will be assessed for usability and potential impacts on meeting site characterization objectives. This assessment will be presented in the investigation report. 


\subsection{References}

ASTM, see American Society for Testing and Materials.

American Society for Testing and Materials. 1995. Standard Guide for Risk-Based Corrective Action Applied at Petroleum Release Sites/American Society for Testing and Materials, ASTM E 1739-95 (Reapproved 2002). Philadelphia, PA.

American Society for Testing and Materials. 2000. Standard Test Method for Radiochemical Determination of Uranium Isotopes in Soil by Alpha Spectrometry, ASTM C 1000-00. West Conshohocken, PA: ASTM International.

American Society for Testing and Materials. 2002. Standard Test Method for Radiochemical Determination of Plutonium in Soil by Alpha Spectroscopy, ASTM C 1001-00.

West Conshohocken, PA: ASTM International.

BN, see Bechtel Nevada.

Bechtel Nevada. 1995. Nevada Test Site Performance Objective for Certification of Nonradioactive Hazardous Waste, Rev. 0, G-E11/96.01. Las Vegas, NV.

CFR, see Code of Federal Regulations.

Code of Federal Regulations. 2003a. Title 10 CFR, Part 835, “Occupational Radiation Protection.” Washington, D.C.: U.S. Government Printing Office.

Code of Federal Regulations. 2003b. Title 40 CFR, Parts 260-282, "Hazardous Waste Management System: General.” Washington, D.C.: U.S. Government Printing Office.

Code of Federal Regulations. 2003c. Title 40 CFR, Parts 761, "Polychlorinated Biphenyls (PCBs) Manufacturing, Processing, Distribution in Commerce, and Use Prohibitions.” Washington, D.C.: U.S. Government Printing Office.

Code of Federal Regulations. 2003d. Title 40 CFR, Part 763, “Asbestos.” Washington, D.C.: U.S. Government Printing Office.

DOE, see U.S. Department of Energy.

DOE/NV, see U.S. Department of Energy, Nevada Operations Office.

EPA, see U.S. Environmental Protection Agency. 
EG\&G Rocky Flats. 1991. General Radiochemistry and Routine Analytical Services Protocol (GRASP), Version 2.1, July. Golden, CO: Environmental Management Department.

FFACO, see Federal Facility Agreement and Consent Order.

Federal Facility Agreement and Consent Order. 1996 (as amended). Agreed to by the State of Nevada, the U.S. Department of Energy, and the U.S. Department of Defense.

Garcia, A. Lawrence Livermore National Laboratory. 2000. Record of Telecon with J. Tinney (SAIC) concerning the Super Kukla Facility in Area 27 (CAU 118/CAS 27-41-01), 8 June. Las Vegas, NV.

Hannon, W.J. and H.L. McKague. 1975. Paper entitled, “An Examination of the Geology and Seismology Associated with Area 410 at the Nevada Test Site,” 23 May. Livermore, CA: Lawrence Livermore National Laboratory.

Holmes \& Narver, Inc. Date unknown. Engineering Drawing A27-5 entitled "Super Kukla Reactor Site.” Las Vegas, NV.

IT, see IT Corporation.

IT Corporation. 1996. Drawing Number 764039.01050000 entitled, "Figure 9-3, Super Kukla Facility Mechanical Equipment and Relay Station Floor Plans,” 13 March. Las Vegas, NV.

Kelly, B., Los Alamos National Laboratory. 2000. Record of Telecon with J. Markowsky (SAIC) concerning the Super Kukla Facility in Area 27 (CAU 118/CAS 27-41-01), 15 June. Las Vegas, NV.

LLNL, see Lawrence Livermore National Laboratory.

LRL, see Lawrence Livermore National Laboratory, Lawrence Radiation Laboratory.

Lawrence Livermore National Laboratory. 1973. Paper entitled, "Super Kukla Operating Experience, 1964-1973,” 16 February. Prepared by L.R. Peterson and R.E. Kelley, Jr. Livermore, CA: University of California.

Lawrence Livermore National Laboratory, Lawrence Radiation Laboratory. 1964. Revised Safety Analysis Report for the Super Kukla Prompt Burst Reactor, Rev. 1. UCRL-7695. Prepared by W.S. Gilbert, F.A. Kloverstrom, and F. Rienecker Jr., Livermore, CA.

Lawrence Livermore National Laboratory, Lawrence Radiation Laboratory. 1969. Operating Manual for the Super Kukla Prompt Burst Reactor, November. Livermore, CA: University of California. 
Lawrence Livermore National Laboratory, Lawrence Radiation Laboratory. 1971. Super Kukla Shim Rod Incident - 12/71, January. Livermore, CA: University of California.

Miller, R. 1972. Semiannual Radioactive Waste Report, April. Publisher Unknown.

Moore, J., Science Applications International Corporation. 1999. Memorandum to M. Todd (SAIC) entitled, “Background Concentrations for NTS and TTR Soil Samples,” 3 February. Las Vegas, NV: IT Corporation.

Murphy, T., Bureau of Federal Facilities. 2004. Letter to R. Bangerter (NNSA/NSO) entitled, "Review of Industrial Sites Project Document Guidance for Calculating Industrial Sites Project Remediation Goals for Radionuclides in Soil Using the Residual Radiation (RESRAD) Computer Code.” 19 November. Las Vegas, NV.

NAC, see Nevada Administrative Code.

NBMG, see Nevada Bureau of Mines and Geology.

NCRP, see National Council on Radiation Protection and Measurements.

NDEP, see Nevada Division of Environmental Protection.

NNSA/NSO, see U.S. Department of Energy, National Nuclear Security Administration Nevada Site Office.

NNSA/NV, see U.S. Department of Energy, National Nuclear Security Administration Nevada Operations Office.

Norman Engineering, see Norman Engineering Co., Inc.

NPS, see National Park Service, Department of the Interior.

NRS, see Nevada Revised Statutes.

National Council on Radiation Protection and Measurements. 1999. Recommended Screening Limits for Contaminated Surface Soil and Review of Factors Relevant to Site-Specific Studies/National Council on Radiation Protection and Measurements, NCRP Report No. 129. Bethesda, MD.

National Park Service, Department of the Interior. 2000. Historic American Engineering Record, Nevada Test Site, Super Kukla Facility, HAER No. NV-31. Prepared by H. Drollinger, C. Beck, Las Vegas, NV; and N. Goldenberg, San Francisco, CA.

Nevada Administrative Code. 2004. NAC 444, “Sanitation.” Carson City, NV.

Nevada Administrative Code. 2005a. NAC 445A, "Water Controls.” Carson City, NV. 
Nevada Administrative Code. 2005b. NAC 445A.2272, “Contamination of Soil: Establishment of Action Levels.” Carson City, NV.

Nevada Administrative Code. 2005c. NAC 445A.22705, "Contamination of Soil: Evaluation of Site by Owner or Operator; Review of Evaluation by Division.” Carson City, NV.

Nevada Bureau of Mines and Geology. 1998. Mineral and Energy Resource Assessment of the Nellis Air Force Range, Open-File Report 98-1. Reno, NV.

Nevada Division of Environmental Protection. 1995. Mutual Consent Agreement between the State of Nevada and the U.S. Department of Energy for the Storage of Low-Level Land Disposal Restricted Mixed Waste. Carson City, NV.

Nevada Division of Environmental Protection. 1997a. Class II Solid Waste Disposal Site for Municipal and Solid Waste, Area 23 of the NTS, Permit SW 13-097-04. Carson City, NV.

Nevada Division of Environmental Protection. 1997b (as amended in August 2000). Class III Solid Waste Disposal Site for Hydrocarbon Burdened Soils, Area 6 of the NTS, Permit SW 1309702. Carson City, NV.

Nevada Division of Environmental Protection. 1997c (as amended in August 2000). Class III Solid Waste Disposal Site; UIOC, Area 9 of the NTS, Permit SW 13-097-03. Carson City, NV.

Nevada Division of Environmental Protection. 1999. State of Nevada Water Pollution Control General Permit, No. GNEV93001. Carson City, NV.

Nevada Division of Environmental Protection. 2000. Nevada Test Site Permit for Hazardous Waste Management Facility (NEV HW0009). Las Vegas, NV.

Nevada Revised Statutes. 2005a. NRS 444.440 - 444.620, “Collection and Disposal of Solid Waste.” Carson City, NV.

Nevada Revised Statutes. 2005b. NRS 459.400 - 459.600, “Disposal of Hazardous Waste.” Carson City, NV.

Nevada Revised Statutes. 2005c. NRS 618.750-618.840 “Control of Asbestos.” Carson City, NV.

Norman Engineering Co., Inc. 1964a. As-built engineering drawing NV-35-08-01 (sheet 14 of 44) entitled, “Super Kukla Facility Containment Building Plan, Section, and Details,” 7 April. Los Angeles, CA.

Norman Engineering Co., Inc. 1964b. As-built engineering drawing NV-35-08-01 (sheet 15 of 44) entitled, "Super Kukla Facility Containment Building Foundation and Floor Plans," 7 March. Los Angeles, CA. 
Norman Engineering Co., Inc. 1964c. As-built engineering drawing NV-35-08-01 (sheet 24 of 44) entitled, "Super Kukla Facility Mech. Equip. Bldg. and Relay Station Bldg. Foundation Plans," 7 April. Los Angeles, CA.

Norman Engineering, Co., Inc. 1964d. As-built engineering drawing NV-35-08-01 (sheet 27 of 44) entitled, “Super Kukla Facility Mechanical Plot Plan,” 3 April. Las Vegas, NV.

Norman Engineering Co., Inc. 1968. As-built engineering drawing NV-35-08-03 (sheet 7 of 22) entitled, "Super Kukla Facility Addition Containment Building, High Bay Elevations and Section,” 15 November. Los Angeles, CA.

Paar, J.G., and D.R. Porterfield. 1997. Evaluation of Radiochemical Data Usability, April, ES/ER/MS-5. Oak Ridge, TN: U.S. Department of Energy.

Peterson, L.R., Lawrence Livermore National Laboratory. 1979. Memo to G.G. Staehle entitled, “The Super Kukla Facility Report In Standby Status Transition,” 5 July. University of California: Livermore, CA.

Roy, T., Lawrence Livermore National Laboratory. 1994. Record of Telecon with L. Whitesides (ITLV) concerning the Super Kukla Facility in Area 27 (CAU 118/CAS 27-41-01), 2 March. Las Vegas, NV.

SNJV, see Stoller-Navarro Joint Venture.

Stoller-Navarro Joint Venture. 2006. Field Instruction for Corrective Action Unit 118: Super Kukla, Nevada Test Site, Nevada, Rev. 0. Las Vegas, NV.

Strand, D., Stoller-Navarro Joint Venture. 2005. Record of Telecon with H. Hernandez (Lawrence Livermore National Laboratory) concerning the summary of Nov. 9 and 10 Super Kukla discussions with Abel Garcia, 17 November. Las Vegas, NV.

USC, see United States Code.

United States Code. 1976. 15 USC 2601 et seq., “Toxic Substances Control Act.” Enacted by Public Law No. 94-469, as amended. Washington, D.C.: U.S. Government Printing Office.

U.S. Department of Energy. 1993. Radiation Protection of the Public and the Environment, DOE Order 5400.5, Change 2. Washington, D.C.: U.S. Government Printing Office.

U.S. Department of Energy. 1997. The Procedures Manual of the Environmental Measurements Laboratory, HASL-300, 28th Ed., Vol.I. New York, NY.

U.S. Department of Energy, National Nuclear Security Administration Nevada Operations Office. 2002a. Industrial Sites Quality Assurance Project Plan, Nevada Test Site, Nevada, Rev. 3, DOE/NV--372. Las Vegas, NV. 
U.S. Department of Energy, National Nuclear Security Administration Nevada Operations Office. 2002b. Underground Test Area Project Waste Management Plan, DOE/NV--343-Rev. 2. Las Vegas, NV.

U.S. Department of Energy, National Nuclear Security Administration Nevada Site Office. 2004. NV/YMP Radiological Control Manual, Rev. 5, DOE/NV/11718-079, UC-702. Prepared by A.L. Gile of Bechtel Nevada. Las Vegas, NV.

U.S. Department of Energy, National Nuclear Security Administration Nevada Site Office. 2005. Nevada Test Site Waste Acceptance Criteria, DOE/NV--325, Rev. 6. Las Vegas, NV.

U.S. Department of Energy, National Nuclear Security Administration Nevada Site Office. 2006. Industrial Sites Project Establishment of Final Action Levels, Rev. 0, DOE/NV--1107. Las Vegas, NV.

U.S. Department of Energy, Nevada Operations Office. 1992. Remedial Investigation and Feasibility Study for the Plutonium Contaminated Soils at Nevada Test Site, Nellis Air Force Range and Tonopah Test Range, April. Las Vegas, NV.

U.S. Department of Energy, Nevada Operations Office. 1993a. Decontamination and Decommissioning Program, Facility Background Information Document, Draft. Las Vegas, NV.

U.S. Department of Energy, Nevada Operations Office. 1993b. Decontamination and Decommissioning Program, Building Decommissioning Data Sheets, Draft. Las Vegas, NV.

U.S. Department of Energy, Nevada Operations Office. 1996. Decontamination and Decommissioning Facilities Evaluation Report, July. Las Vegas, NV.

U.S. Department of Energy, Nevada Operations Office. 1998. Nevada Test Site Resource Management Plan. DOE/NV--518, Las Vegas, NV.

U.S. Department of Energy, Nevada Operations Office. 1999. Resource Conservation and Recovery Act, Part B, Permit Application for Waste Management Activities at the Nevada Test Site. Las Vegas, NV.

U.S. Environmental Protection Agency. 1987. Data Quality Objectives for Remedial Response Activities, EPA/540/G-87/003. Washington, D.C.

U.S. Environmental Protection Agency. 1988. Contract Laboratory Program Statement of Work for Inorganic Analysis, SOW No. 788, EPA/540/R-94/093. Washington, D.C.

U.S. Environmental Protection Agency. 1994. Contract Laboratory Program Statement of Work for Inorganic Analysis, ILMO 3.0, EPA/540/R-94/076. Washington, D.C. 
U.S. Environmental Protection Agency. 1995. Contract Laboratory Program Statement of Work for Inorganic Analysis, ILMO 4.0, EPA/540/R-95/121. Washington, D.C.

U.S. Environmental Protection Agency. 1996. Test Method for Evaluating Solid Waste Physical/Chemical Methods, SW-846, 3rd Edition. Washington, D.C.

U.S. Environmental Protection Agency. 1999. Contract Laboratory Program Statement of Work for Organic Analysis, OCM 04.3. Washington, D.C.

U.S. Environmental Protection Agency. 2000a. Data Quality Objectives Process for Hazardous Waste Site Investigations. EPA QA/G-4HW. Washington, D.C.

U.S. Environmental Protection Agency. 2000b. Guidance for the Data Quality Objectives Process. EPA QA/G4. Washington, D.C.

U.S. Environmental Protection Agency. 2001. Guidance on Data Quality Indicators, EPA QA/G-5i. Washington, D.C.

U.S. Environmental Protection Agency. 2002. Guidance for Quality Assurance Project Plans, EPAQA/G5. Washington, D.C.

U.S. Environmental Protection Agency. 2005. Region 9 Preliminary Remediation Goals (PRGs). As accessed at http://www.epa.gov/region09/waste/sfund/prg/index.htm on 28 June 2006. Prepared by S.J. Smucker. San Francisco, CA. 


\section{Appendix A}

\section{Project Organization}




\section{A.1.0 Project Organization}

The NNSA/NSO Federal Sub-Project Manager is Kevin Cabble. He can be contacted at (702) 295-5000. The NNSA/NSO Task Manager is Sabine Curtis. She can be contacted at (702) 295-0542.

The identification of the project Health and Safety Officer and the Quality Assurance Officer can be found in the appropriate plan. However, personnel are subject to change and it is suggested that the appropriate DOE Project Manager be contacted for further information. The Task Manager will be identified in the FFACO Monthly Activity Report before the start of field activities. 


\section{Appendix B}

\section{Engineering Drawings for Site Closure}




\section{B.1.0 Engineering Specifications for Site Closure}

Engineering specifications for site closure are identified below and are located in this section.

- Super Kukla Facility Title Sheet, Legend, Drawing Index, Site Plan and Location Map Sheet Number: T-1

- Super Kukla Facility Grading Plan - Sheet Number: C-1

- $\quad$ Super Kukla Facility Grading Sections - Sheet Number: C-2

- $\quad$ Super Kukla Facility Containment Plan and Sections - Sheet Number: C-3

- $\quad$ Super Kukla Facility Floor Plan - Sheet Number: C-4

- $\quad$ Super Kukla Facility Removable Floor System - Sheet Number: C-5

- Super Kukla Facility Containment Foundation Plans - Sheet Number: C-6

- $\quad$ Super Kukla Facility Containment Sections - Sheet Number: C-7

- $\quad$ Super Kukla Facility Mechanical Plot Plan - Sheet Number: M-1

- $\quad$ Super Kukla Facility Mechanical Equipment Room Plan and Sections - Sheet Number: M-2

- Super Kukla Facility Containment Building Mechanical Plan and Sections Sheet Number: M-3

- $\quad$ Super Kukla Facility Removable Floor System - Detail I: I1

- $\quad$ Super Kukla Facility Removable Floor System - Detail II: I2

- Super Kukla Facility Containment Sections and Details: I3

- Super Kukla Facility Containment Partial Plans and Sections: I4

- Super Kukla Facility Containment Shielding Wall Plan and Sections: I5

- Super Kukla Facility Containment Shielding Wall Details: I6

- $\quad$ Super Kukla Facility Containment Tunnel Entrance: I7 


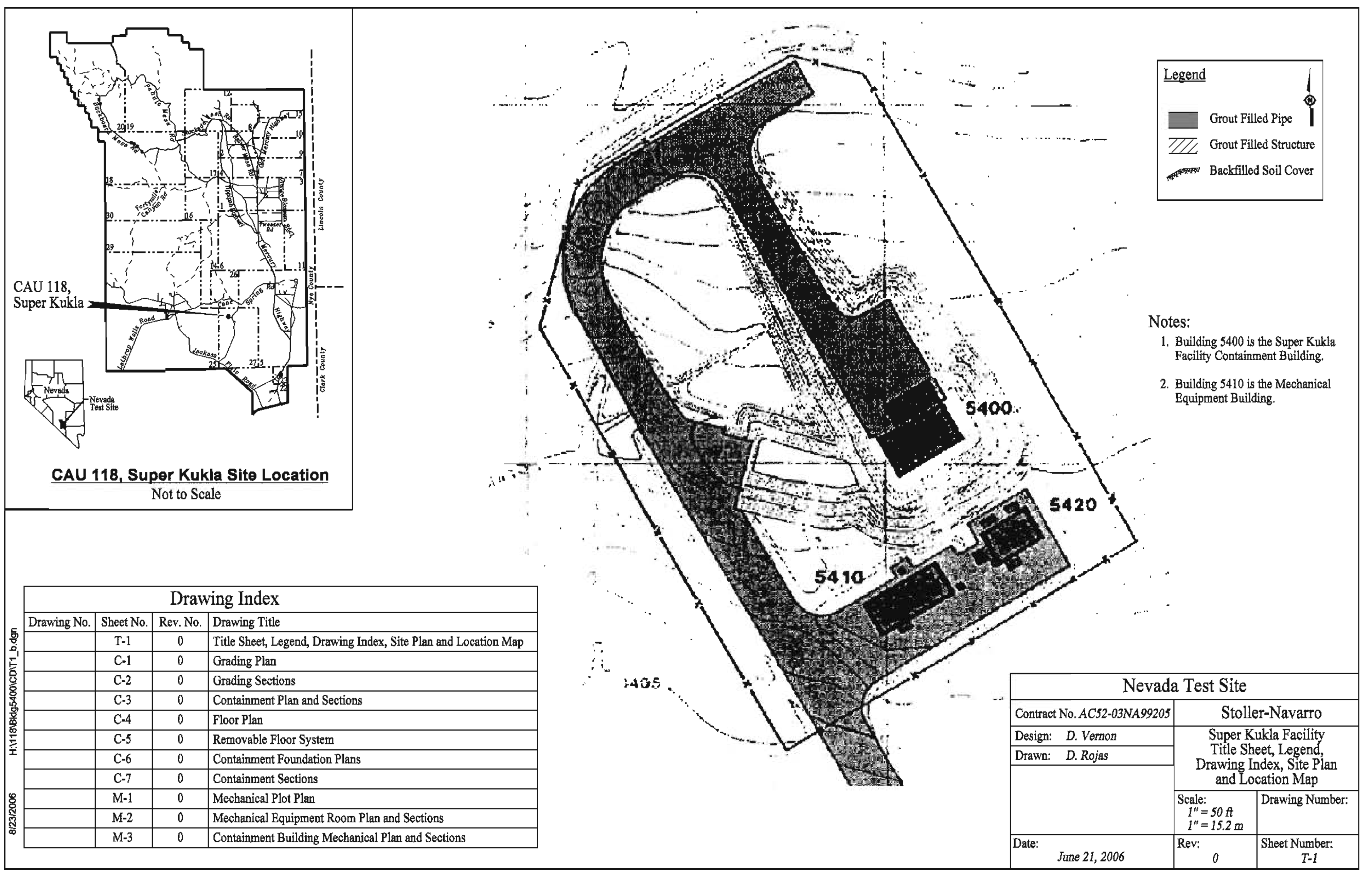

Unterentrodled WherpPPritated 


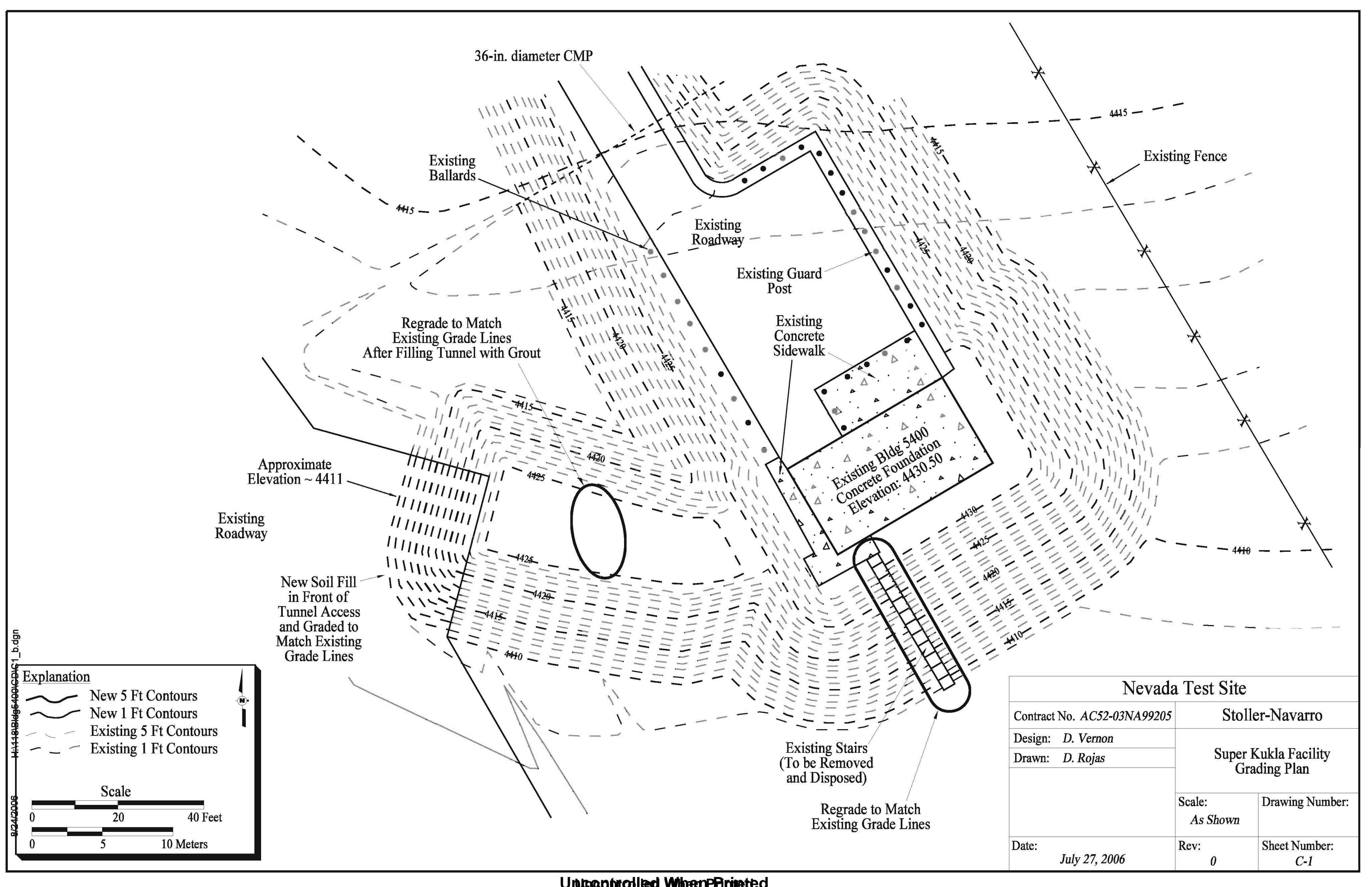

Uriterentitodled WhernPPrivated 

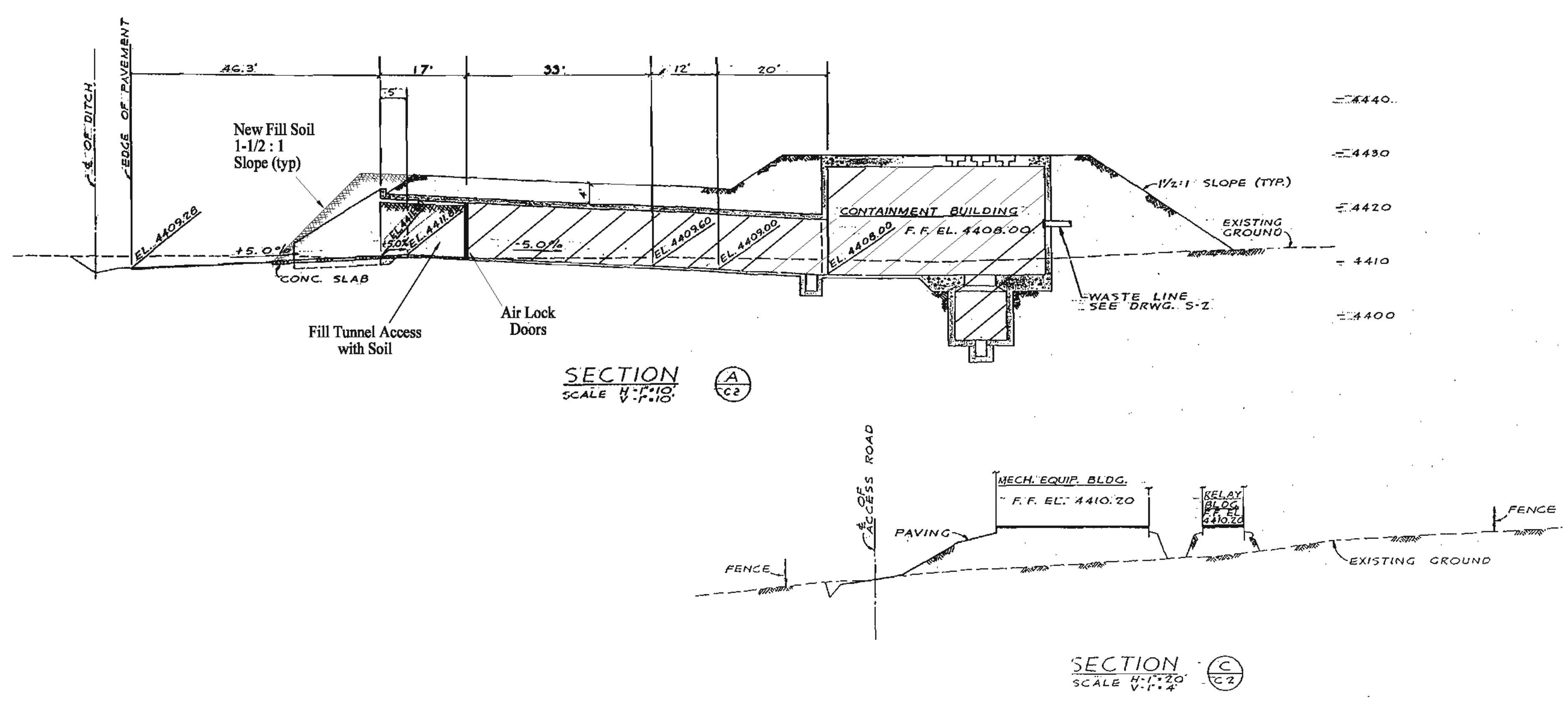

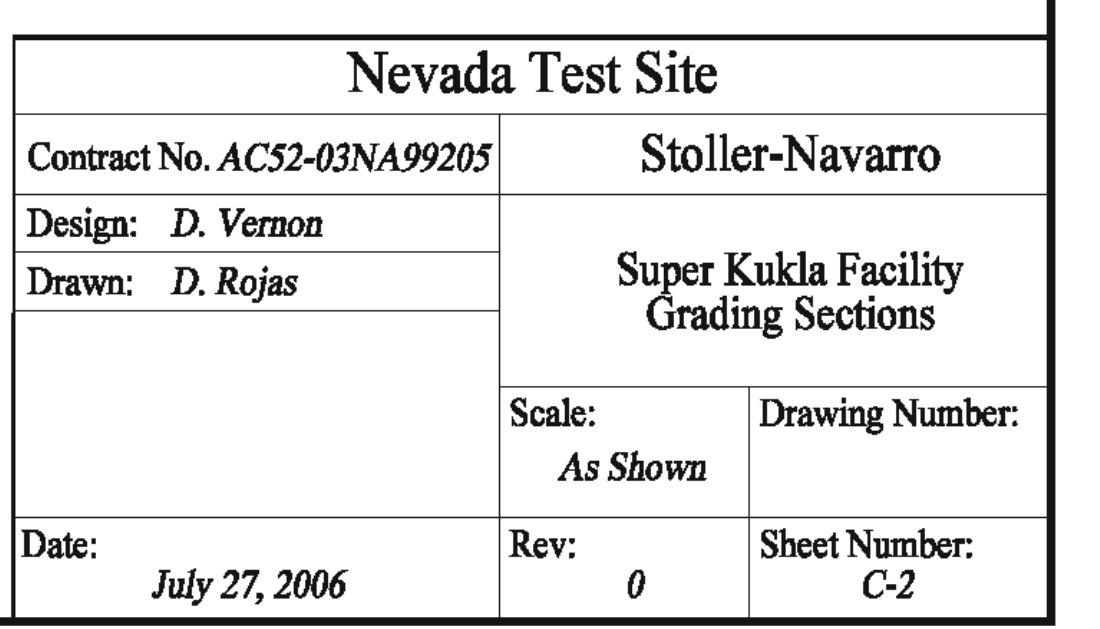




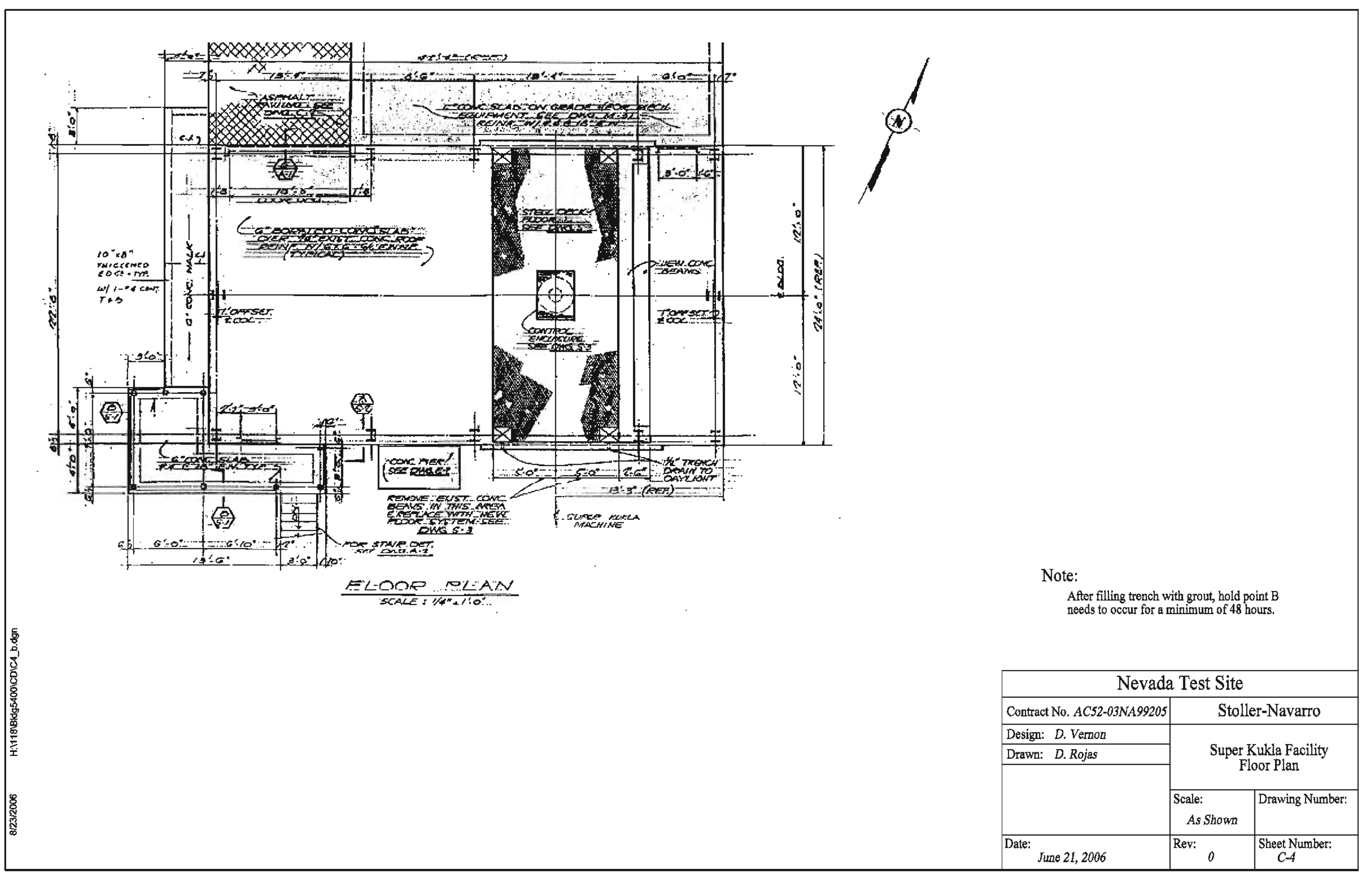




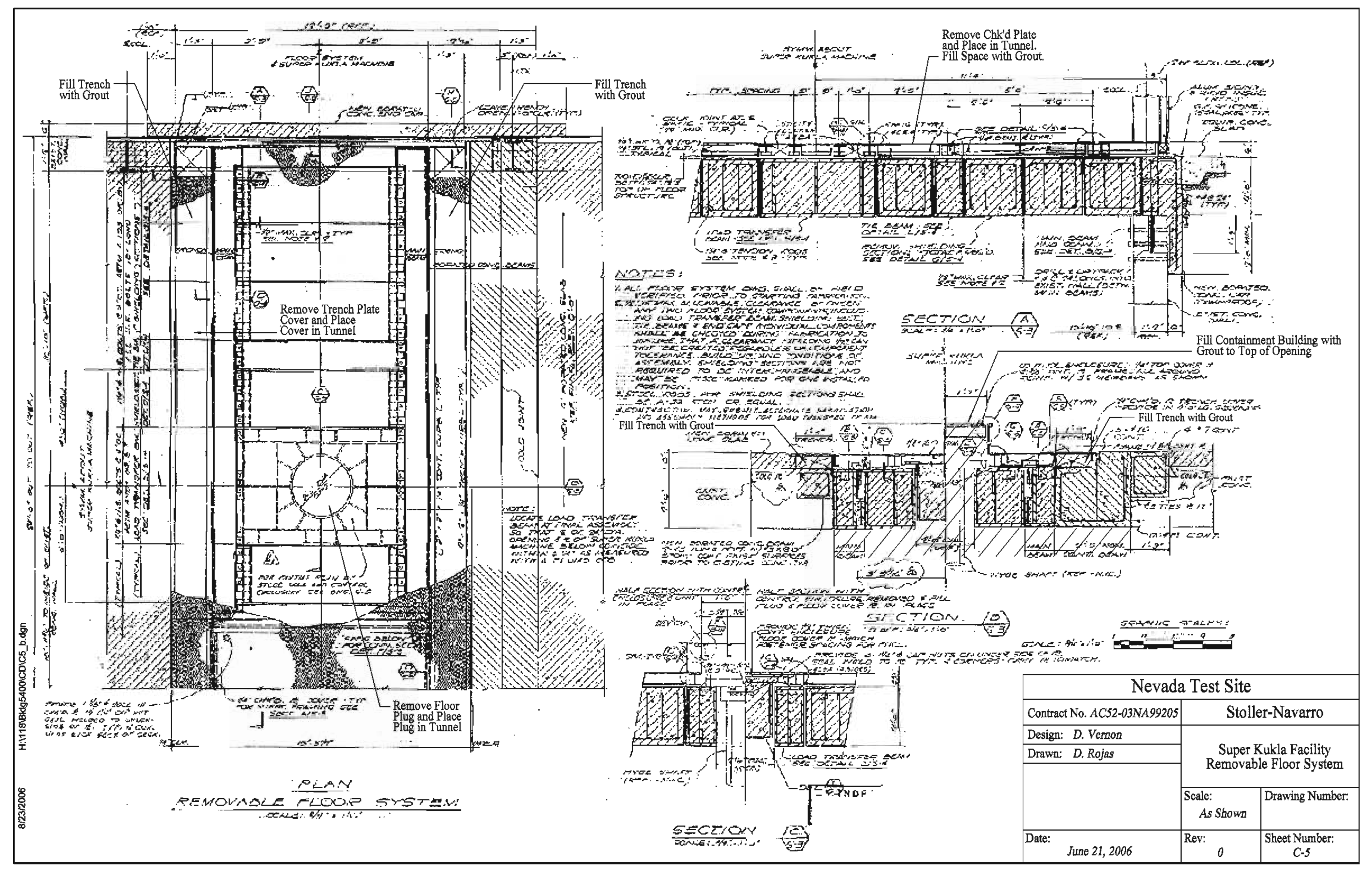

Urterentrodled WhemPPriveted 


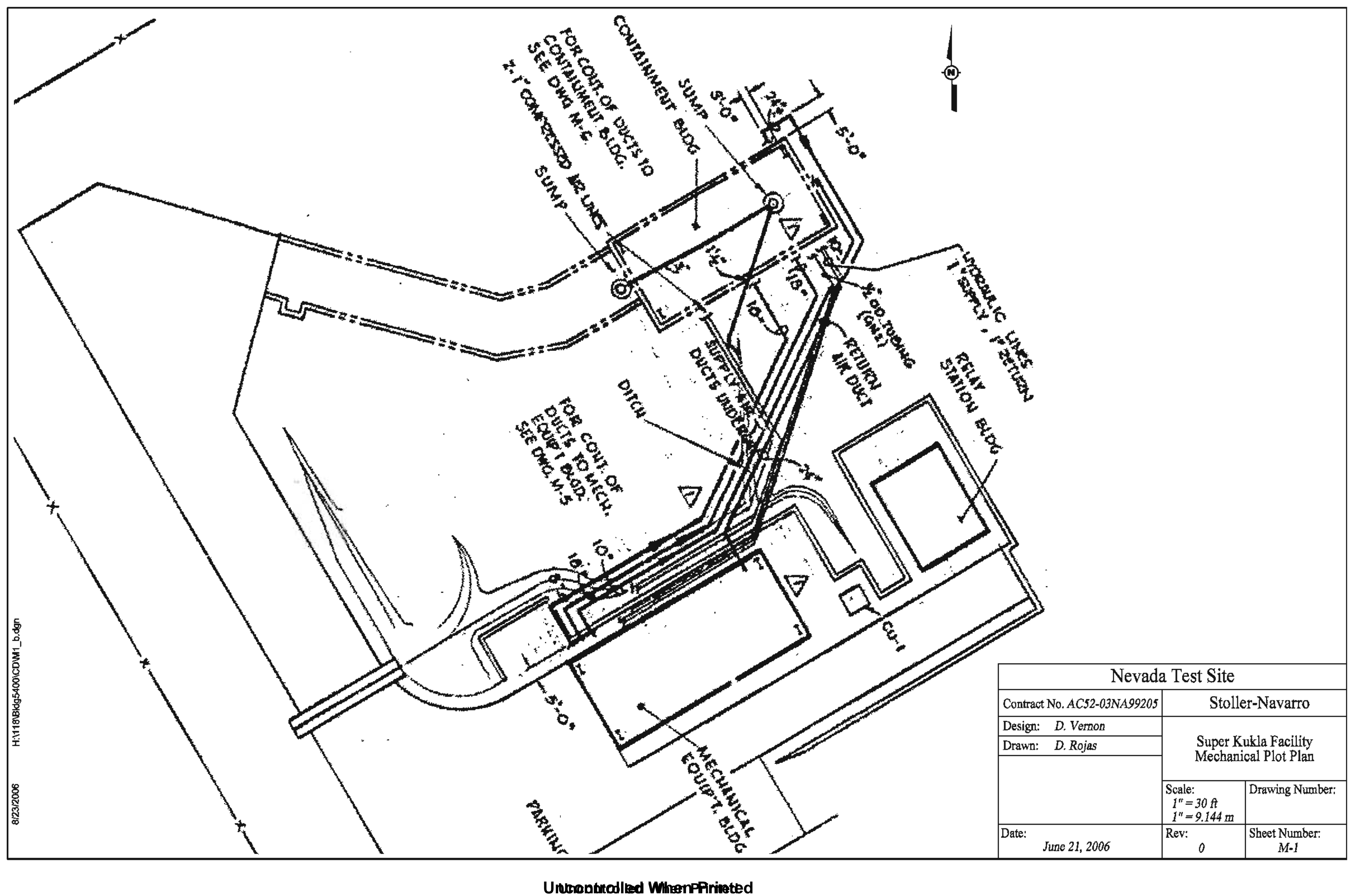




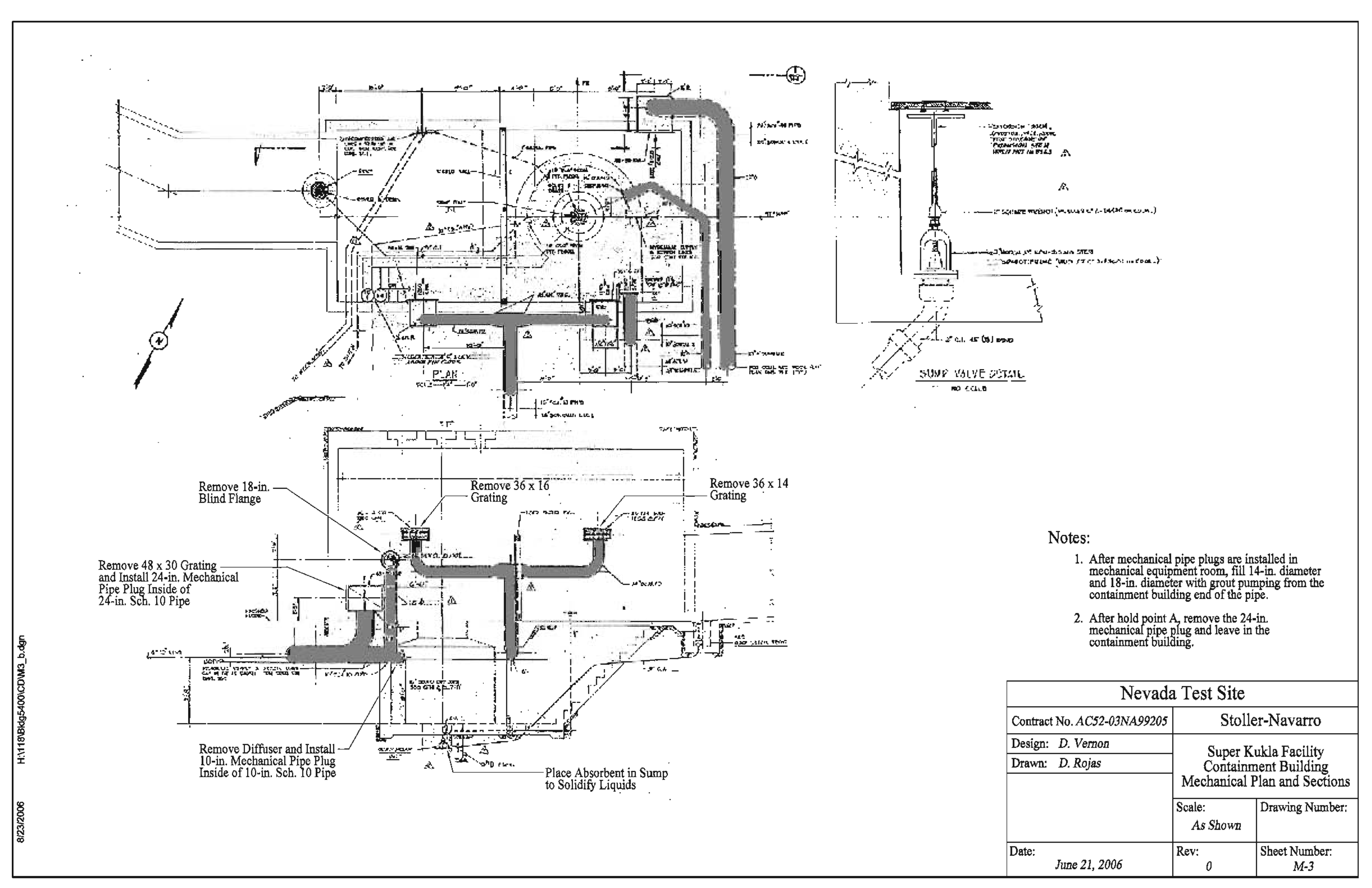

Urterentrodled WhempPrinated 


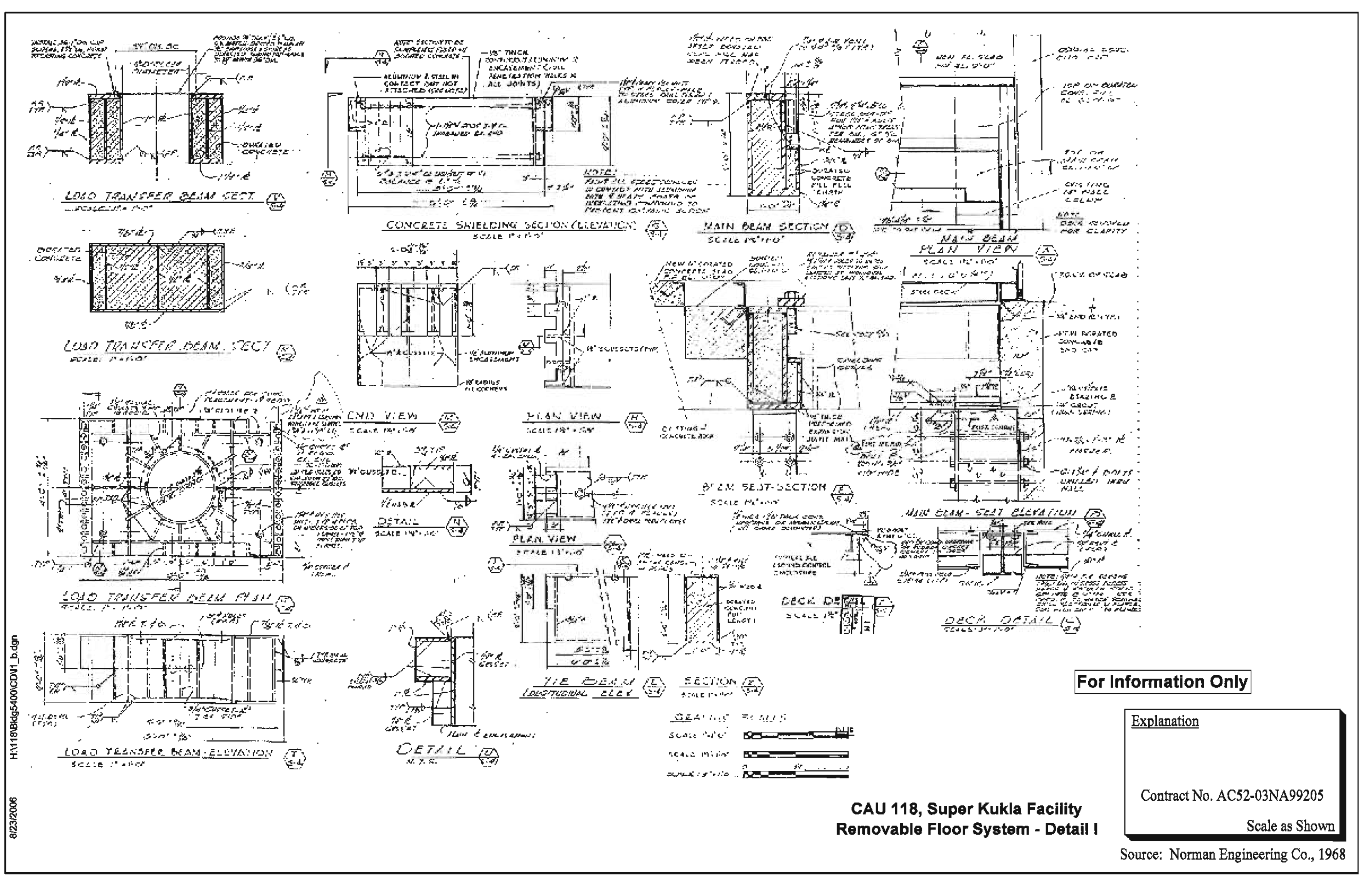




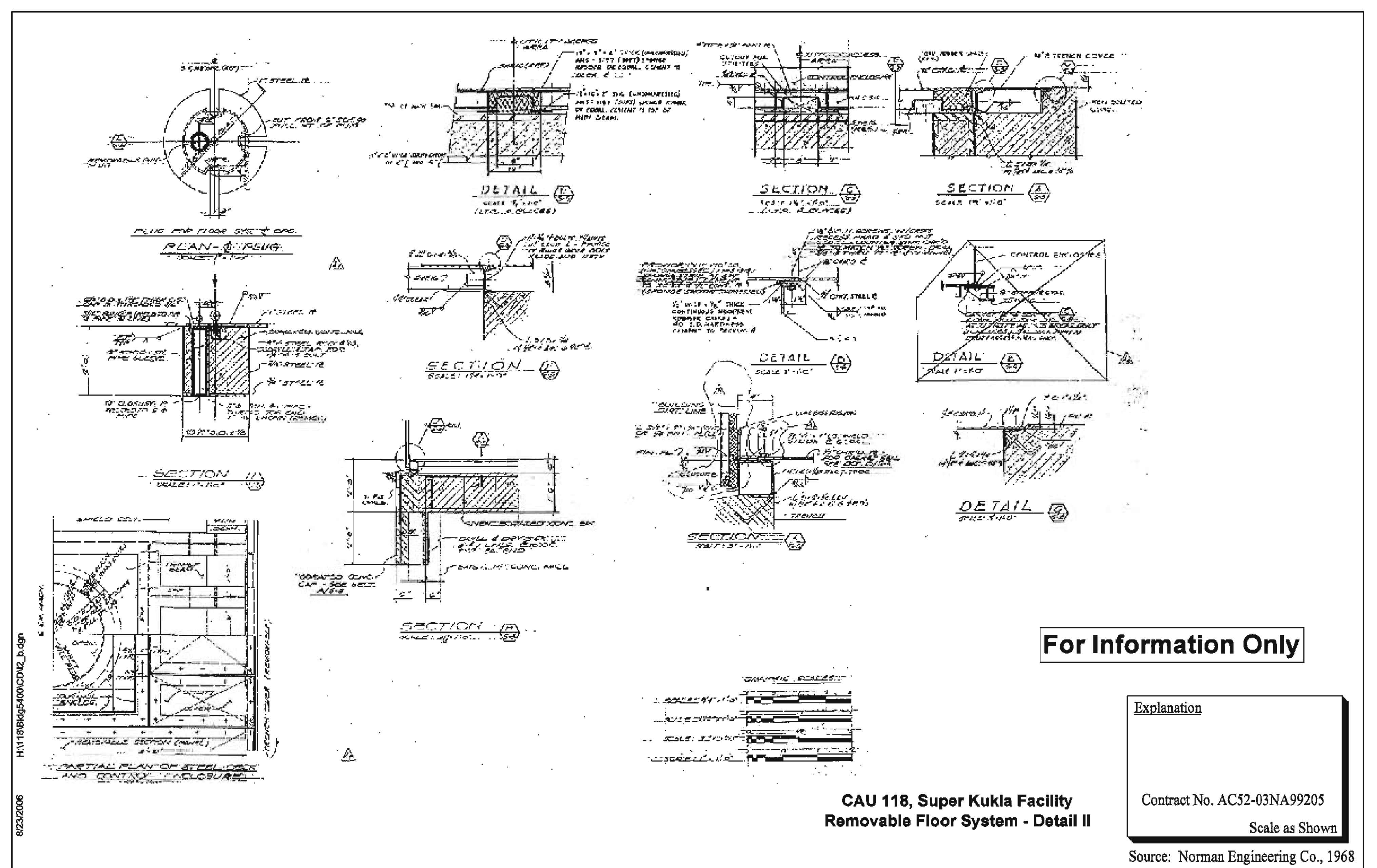




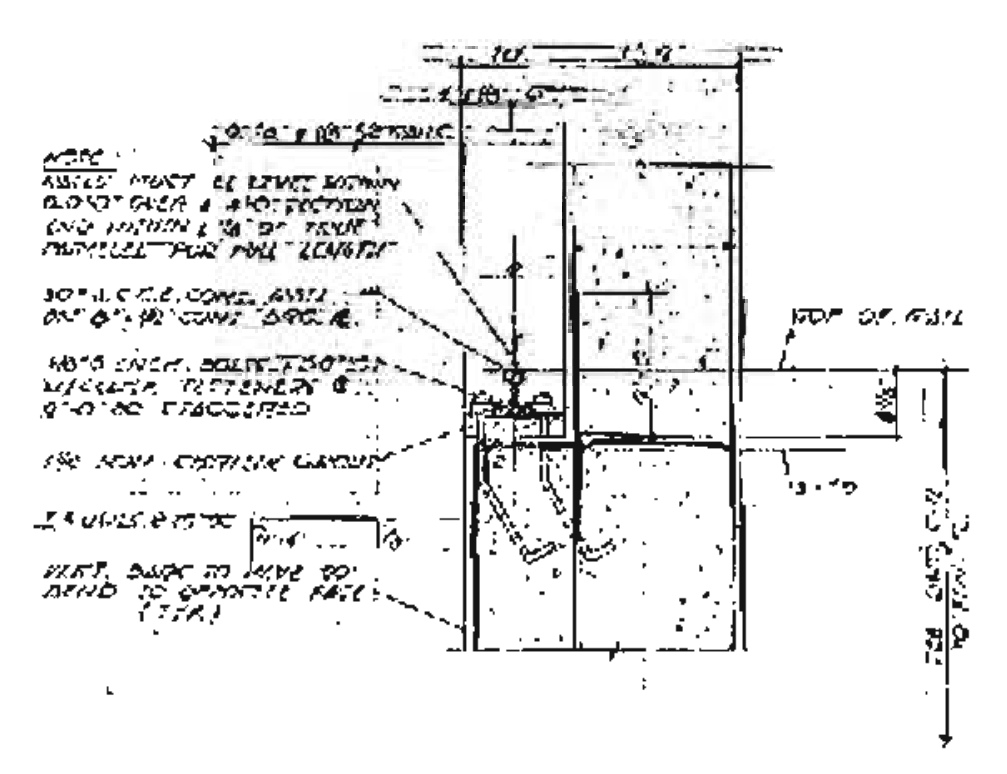

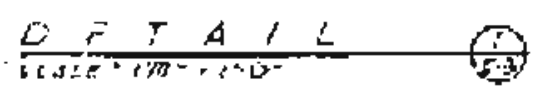

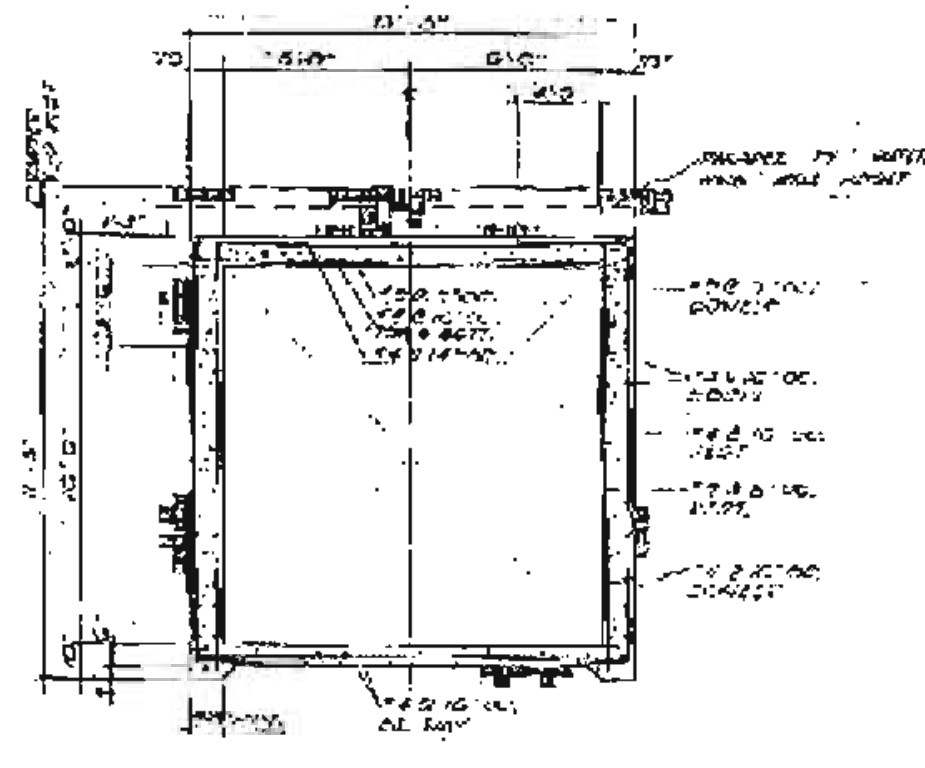

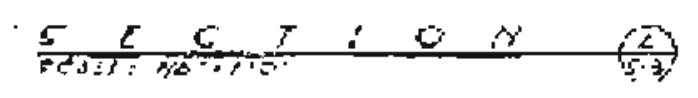

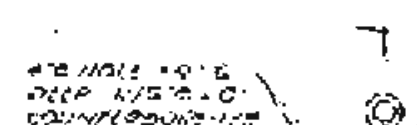

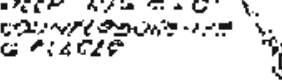

i

$\frac{5}{3}$

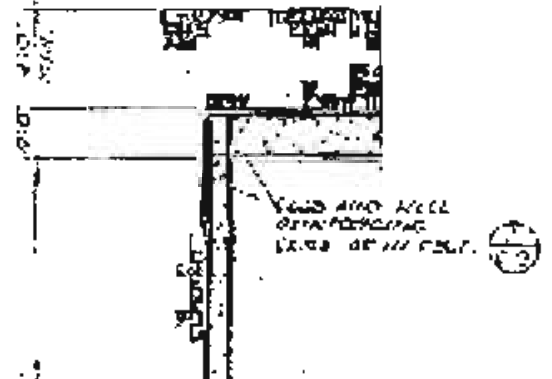

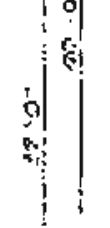<smiles>C=C(C)CC</smiles>

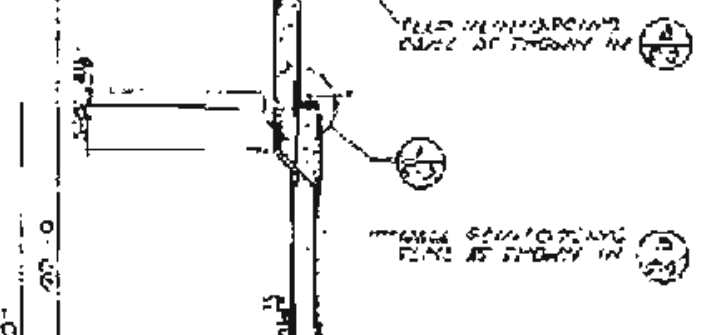
sases

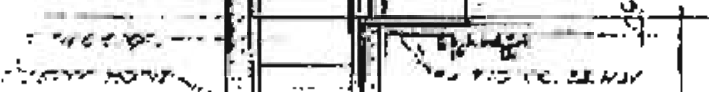

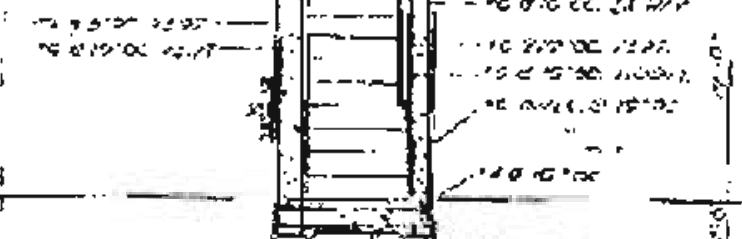

$\Leftrightarrow=\dot{0}, \infty$

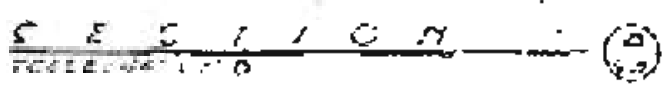

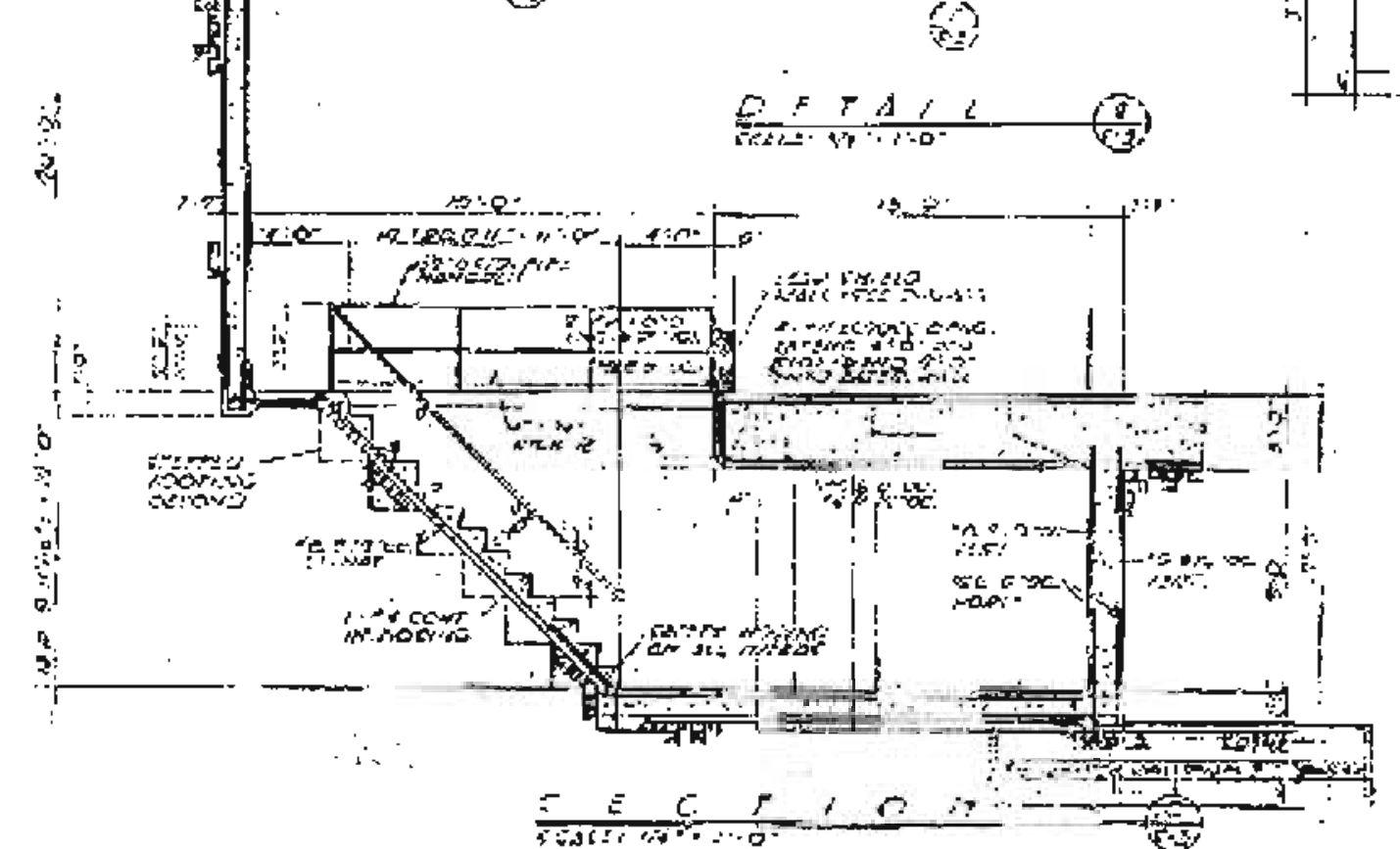

CAU 118, Super Kukla Facility Containment Sections and Details

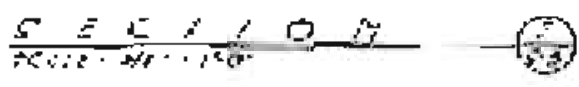

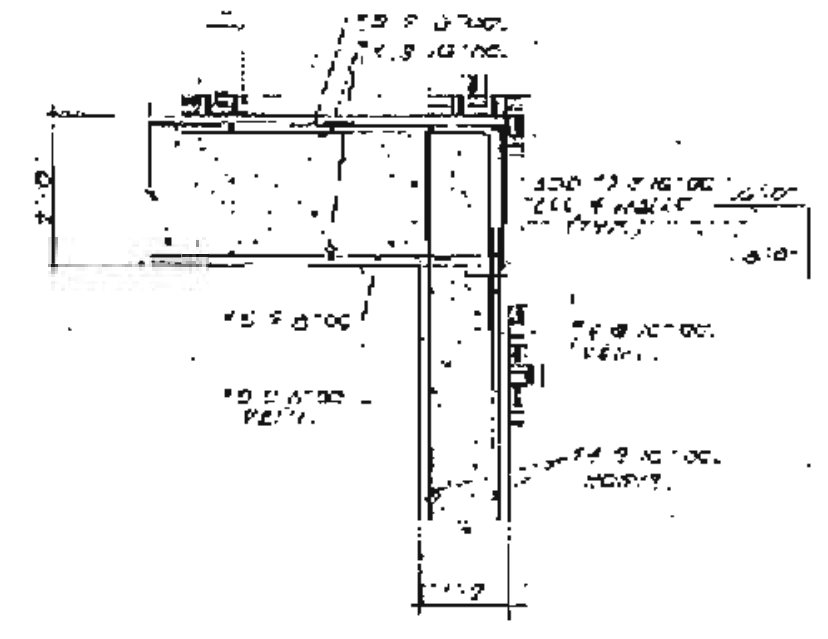

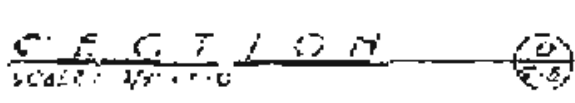

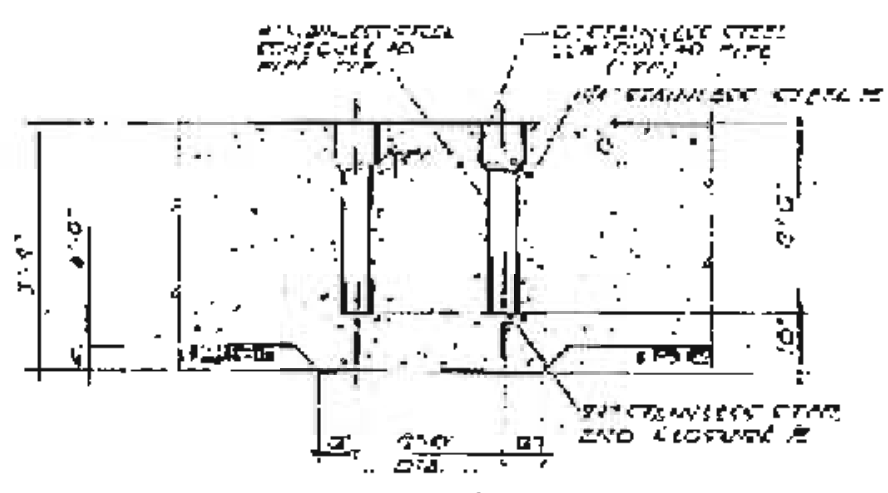

For Information Only

Explanation

Contract No. AC52-03NA99205

Scale at Shown 


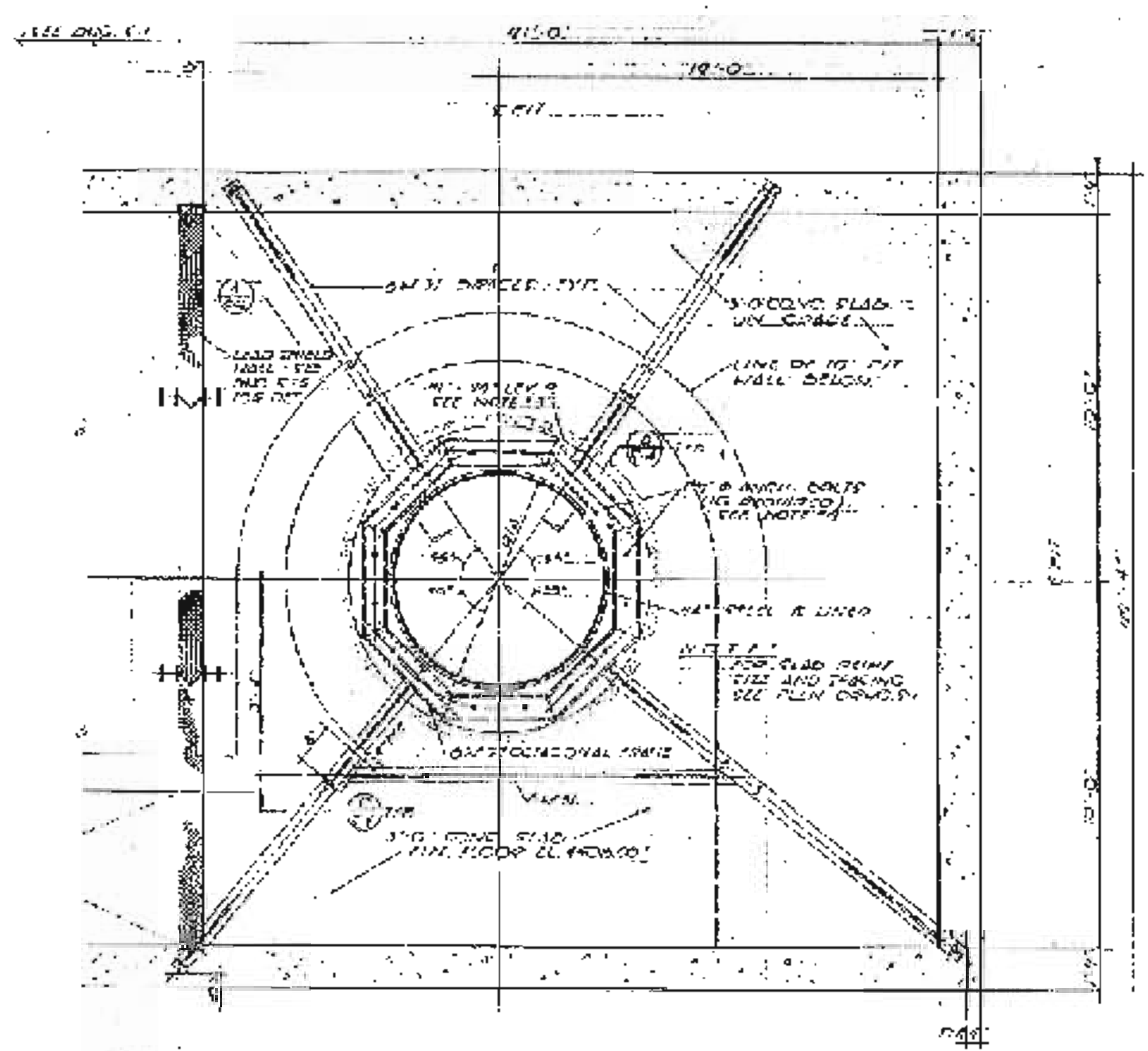

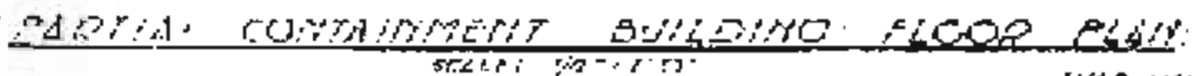

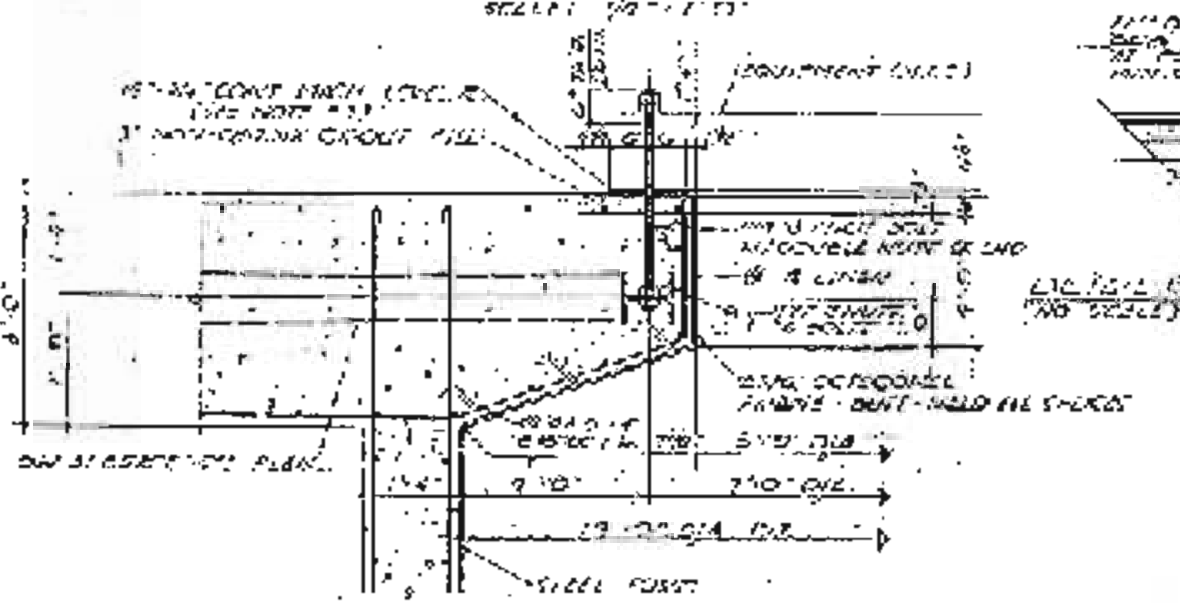

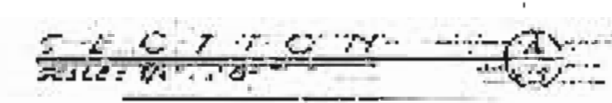

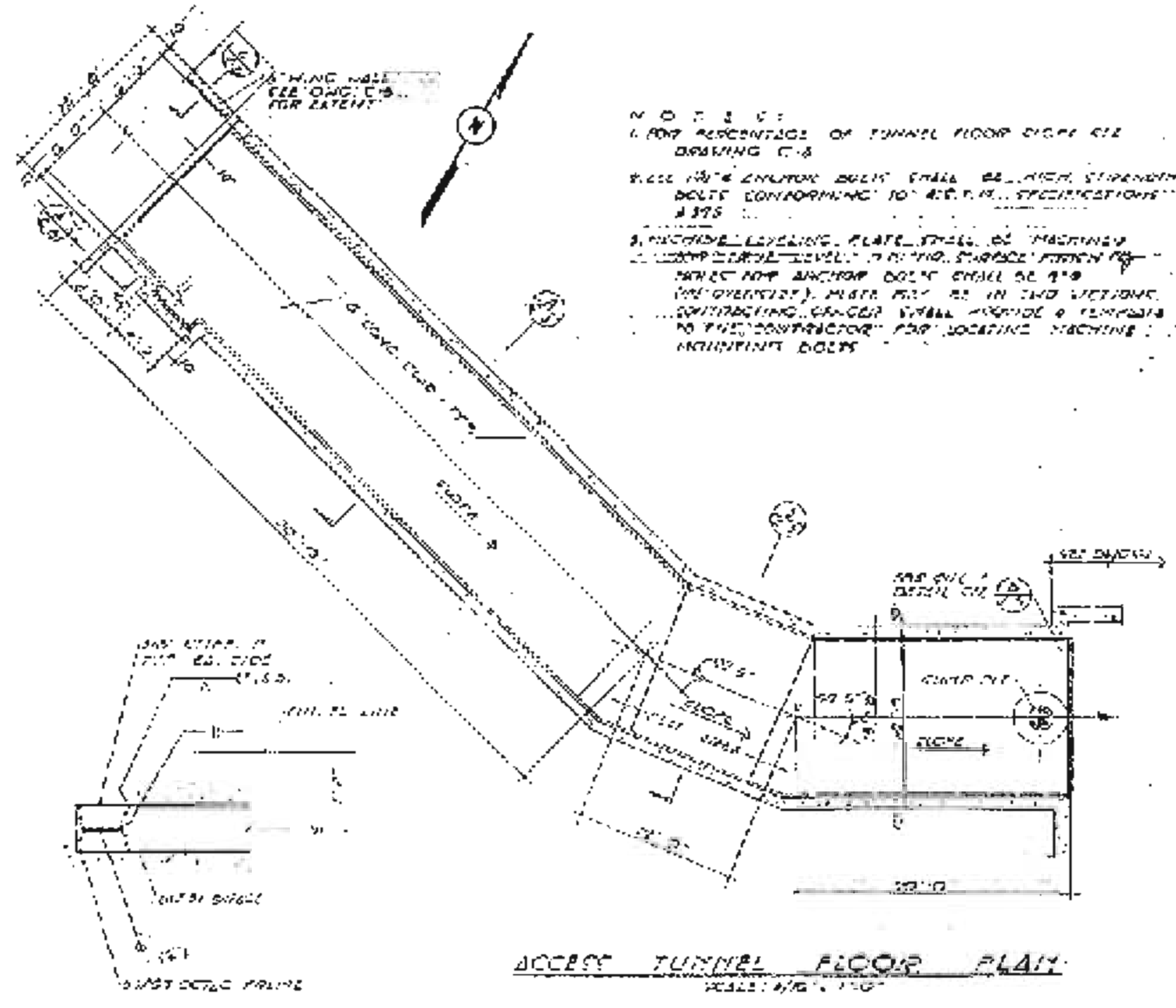

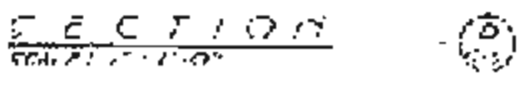

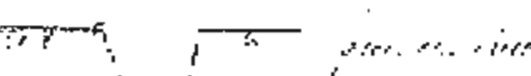

a

os $\sin \cos \theta \sin$

arex

$\cos t \sin$

CAU 118, Super Kukla Facility

Containment Partial Plans and Sections

\section{For Information Only}

Explanation

Contract No. AC52-03NA99205

Scale as Shown

Source: Norman Engineering Co., 1963 


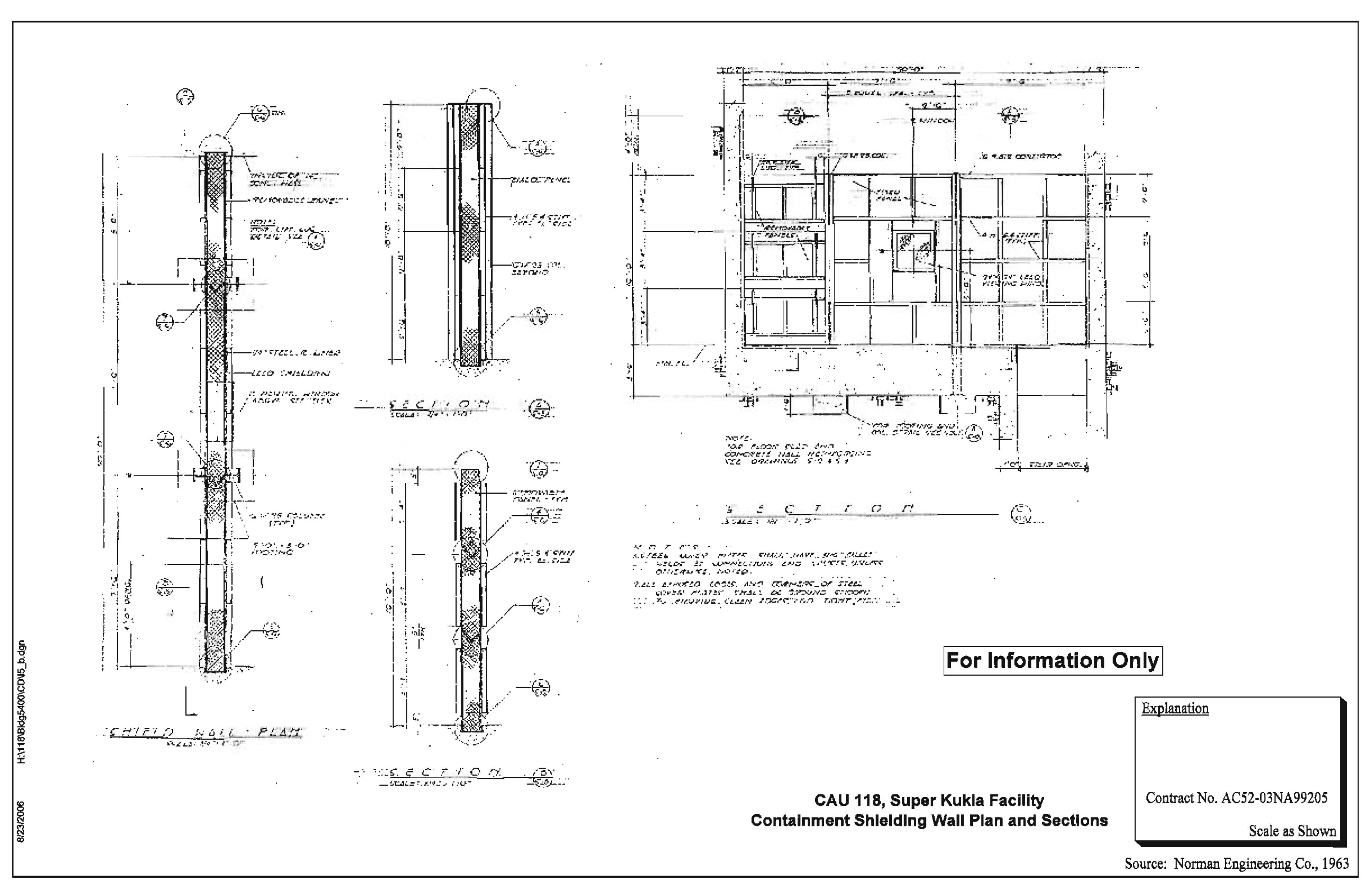




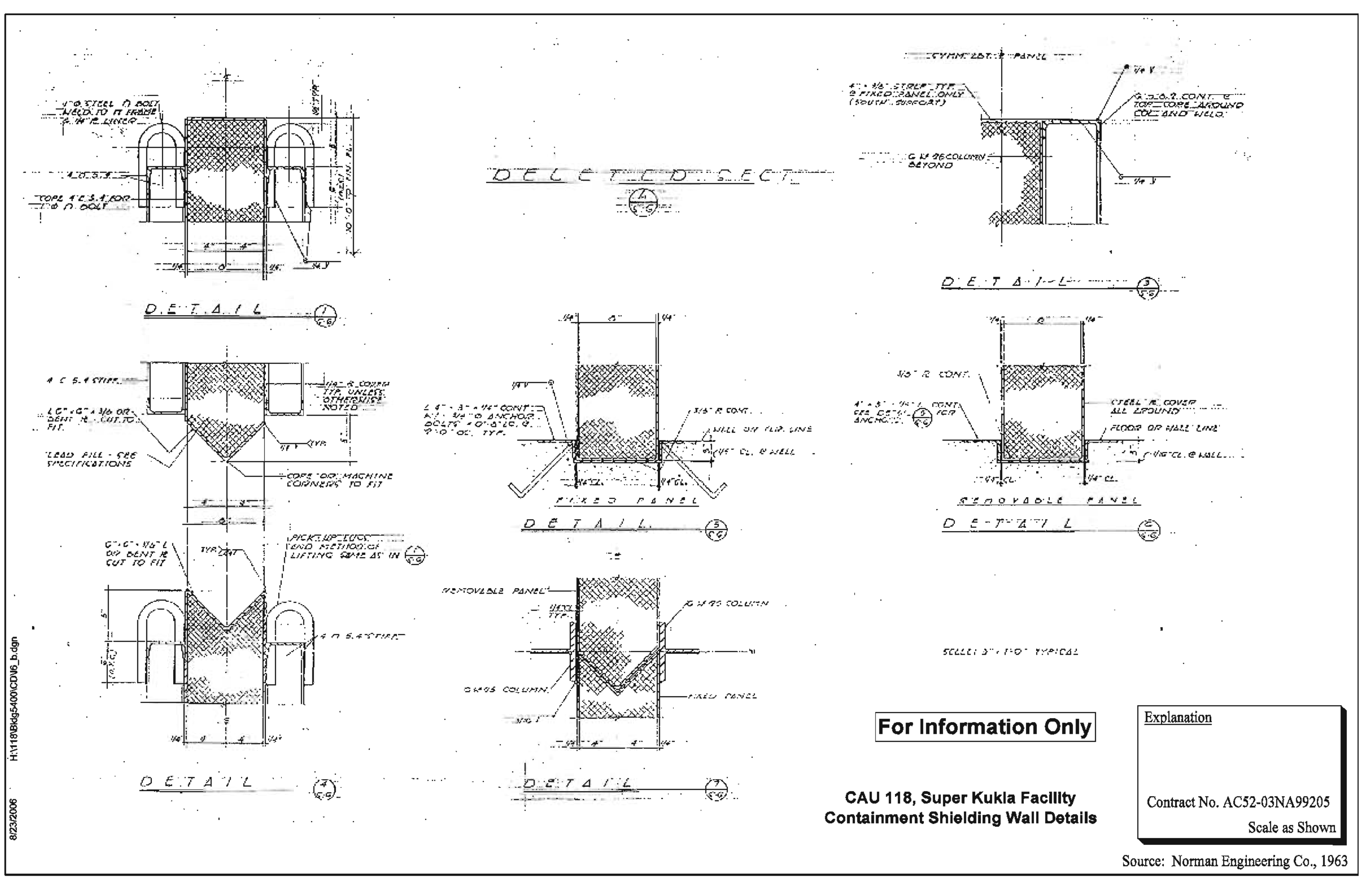

Urterentitodled WheenPPritated 


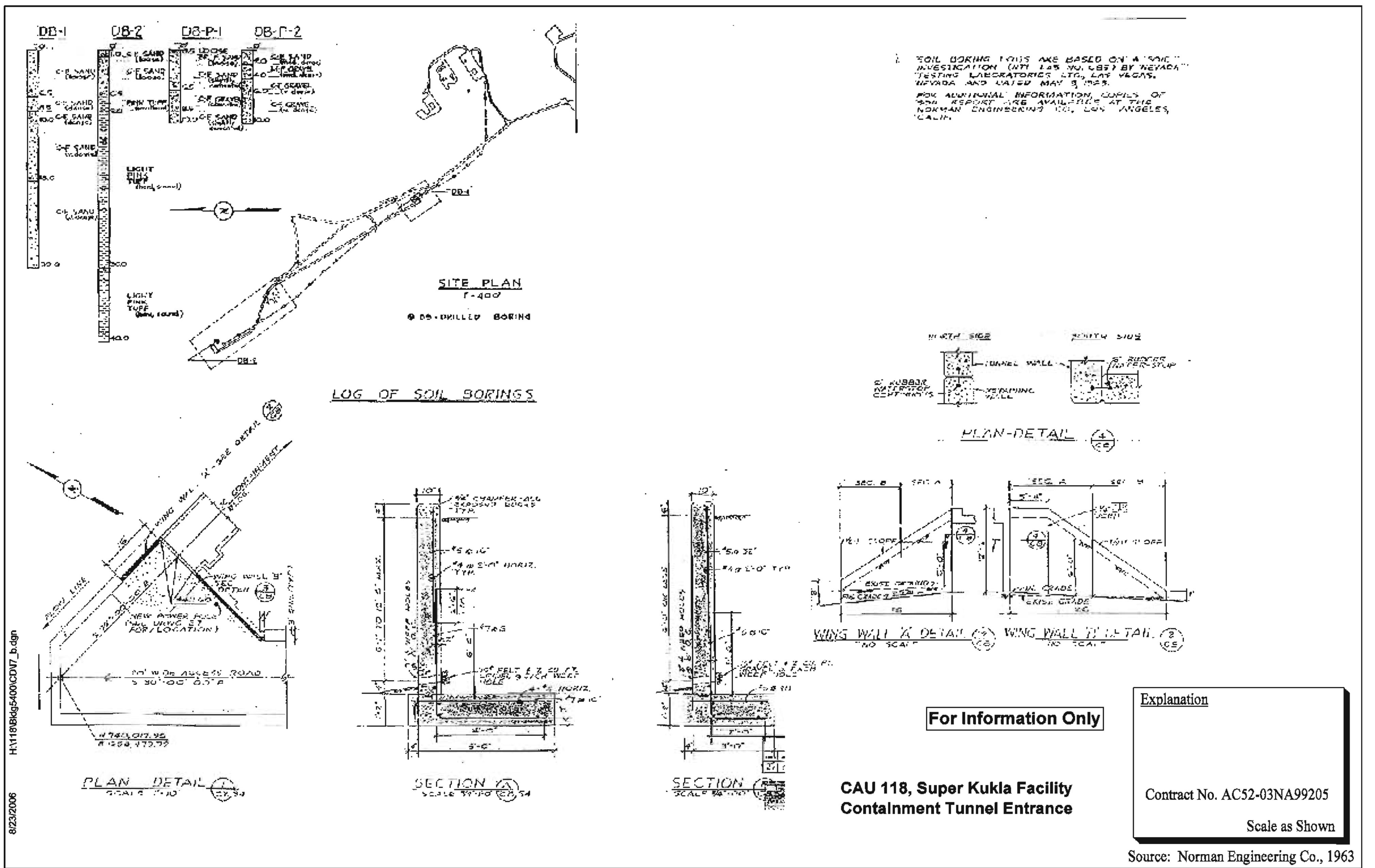




\section{Appendix C}

\section{Alternative Evaluation for the Lead Shielding Wall}




\section{C.1.0 Alternative Evaluation for the Lead Shielding Wall}

The corrective action alternatives (CAAs) of close in place and clean closure of the lead shielding wall located within the Super Kukla Containment Building are qualitatively assessed in this section. The CAA of no further action will not be assessed due to the presence of lead within the wall at concentrations exceeding industrial cleanup standards. This assessment includes a description of the CAAs being considered in Section C.2.0, a description of the screening criteria in Section C.3.0, and an evaluation of the alternatives (based on the screening criteria) described in Section C.4.0. Appendix D of this SAFER provides a quantitative analysis on the justification for leaving the lead shielding wall in place. Figure C.1-1 is a photograph of the lead shielding wall in Building 5400. 


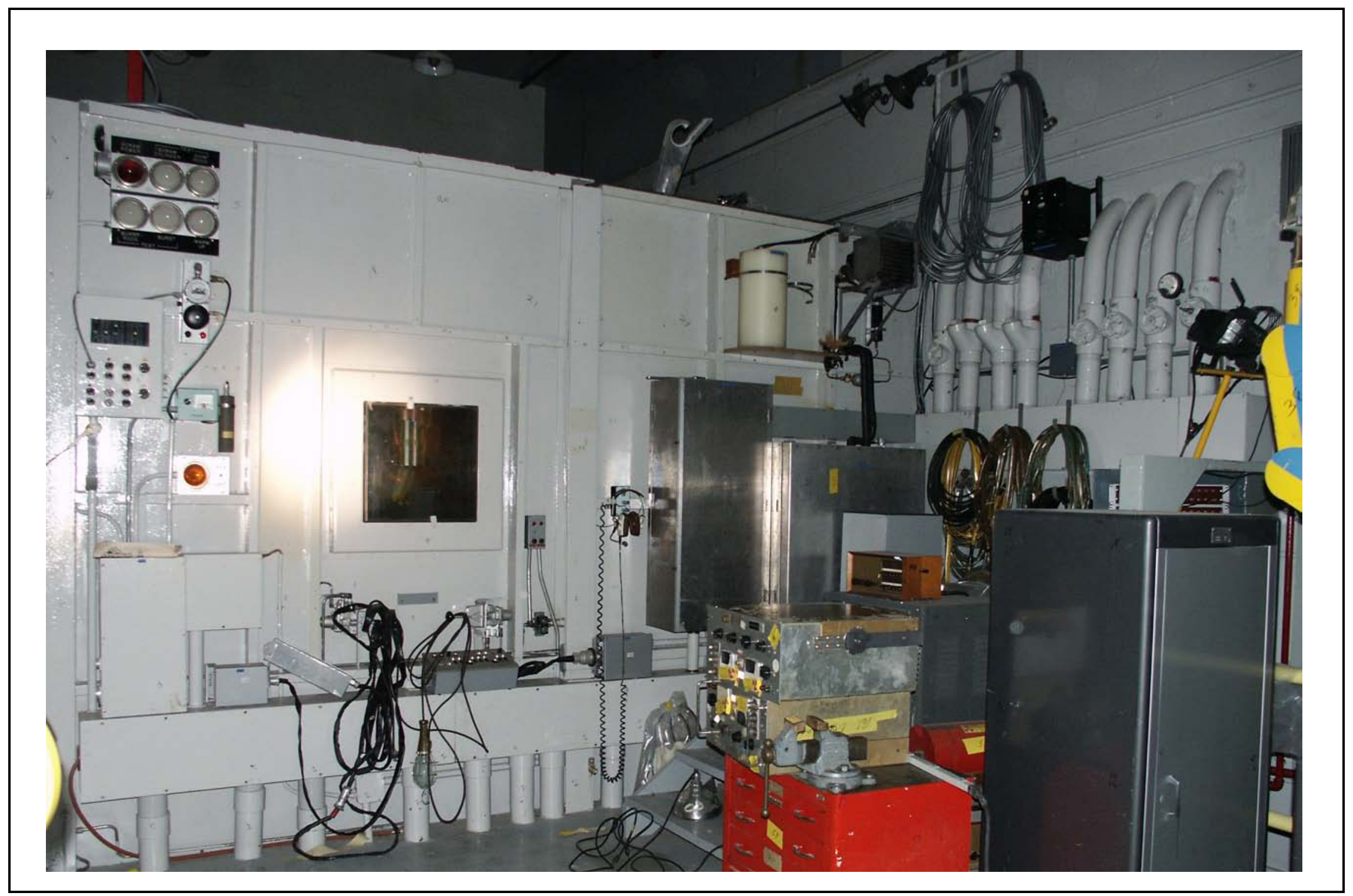

Figure C.1-1

Building 5400 Lead Shielding Wall 


\section{C.2.0 Development of Corrective Action Alternatives}

This section identifies and briefly describes the viable corrective action technologies and the CAAs considered for the lead shielding wall. Based on the review of existing data, future use, and current operations at the NTS, the following alternatives have been developed for consideration:

- Alternative 1 - Clean Closure

- $\quad$ Alternative 2 - Close in Place with Administrative Controls

\section{C.2.1 Alternative 1 - Clean Closure}

The CAA of clean closure would include specific site preparation activities, field activities associated with dismantling and packaging the lead shielding wall, and shipment of the wall to an approved MLLW disposal facility. These steps are listed in more detail below:

- $\quad$ Site Preparation

- Hantavirus cleanup.

- Construct engineering controls, as needed (e.g., air movers, monitoring equipment, shielding curtains, etc.).

- Install a 90-day hazardous waste management area.

- Dismantlement

- Remove equipment, conduit piping, and other items attached to or blocking the removal of the lead wall.

- Remove paint covering the welded seam between the two sections of the lead wall.

- Secure the overhead crane to one of the two sections of the wall, and separate the welding attaching the two sections.

- Packaging

- Lift one section of the lead wall at a time and wrap or containerize as appropriate for staging and disposal.

- Remove the wrapped section of the lead wall through the Building 5400 access tunnel, and transfer to the temporary hazardous waste management area. 
- Repeat for the second section of the lead wall.

- $\quad$ Shipment

- Load both sections of the lead wall onto a flatbed truck for transport to an approved disposal facility.

\section{C.2.2 Alternative 2 - Close in Place with Administrative Controls}

The CAA of close in place would culminate in removing and disposing of all liquids and gases, and much of the hazardous wastes from Building 5400, and encasing the reactor room (including the lead wall) in flowable cement grout. All ventilation, the hydraulic line chase connecting Buildings 5400 and 5410, overpressure well, basement, stairwell, sump, and access tunnel of Building 5400 will also be filled with flowable grout. Engineering specifications to prevent weathering and precipitation infiltration will be implemented as necessary, and an appropriate Use Restriction for the site will be applied. Refer to Section 4.2 of the SAFER document for detailed information on all of the activities to be performed as part of the close in place scenario. 


\section{C.3.0 Screening Criteria}

The screening criteria used to evaluate and select the preferred CAAs are identified in the EPA Guidance on RCRA Corrective Action Decision Documents (EPA, 1991) and the Final RCRA Corrective Action Plan (EPA, 1994).

Corrective action alternatives are evaluated based on four general corrective action standards and five remedy selection decision factors. All CAAs must meet the four general standards to be selected for evaluation using the remedy selection decision factors.

The general corrective action standards are as follows:

- Protection of human health and the environment

- Compliance with media cleanup standards

- Control the source(s) of the release

- Comply with applicable federal, state, and local standards for waste management

The remedy selection decision factors are as follows:

- $\quad$ Short-term reliability and effectiveness

- Reduction of toxicity, mobility, and/or volume

- Long-term reliability and effectiveness

- Feasibility

- Cost

\section{C.3.1 Corrective Action Standards}

The following text describes the corrective action standards used to evaluate the CAAs.

\section{Protection of Human Health and the Environment}

Protection of human health and the environment is a general mandate of the RCRA statute (EPA, 1994). This mandate requires that the corrective action include any necessary protective measures. These measures may or may not be directly related to media cleanup, source control, or management of wastes. The CAAs are evaluated for the ability to be protective of human health and the environment. 


\section{Compliance with Media Cleanup Standards}

The CAAs are evaluated for the ability to meet the proposed media cleanup standards. The media cleanup standards are the final action levels.

\section{Control the Source(s) of the Release}

The CAAs are evaluated for the ability to stop further environmental degradation by controlling or eliminating additional releases that may pose a threat to human health and the environment. Unless source control measures are taken, efforts to clean up releases may be ineffective or, at best, will essentially involve a perpetual cleanup. Therefore, each CAA must provide effective source control to ensure the long-term effectiveness and protectiveness of the corrective action.

\section{Comply with Applicable Federal, State, and Local Standards for Waste Management}

The CAAs are evaluated for the ability to be conducted in accordance with applicable federal and state regulations (e.g., 40 CFR 260-282, “Hazardous Waste Management” [CFR, 2003a]; 40 CFR 761 “Polychlorinated Biphenyls,” [CFR, 2003b]; and NAC 444.842 to 98, “Management of Hazardous Waste” [NAC, 2002]).

\section{C.3.2 Remedy Selection Decision Factors}

The following text describes the remedy selection decision factors used to evaluate the CAAs.

\section{Short-Term Reliability and Effectiveness}

Each CAA must be evaluated with respect to its effects on human health and the environment during implementation of the selected corrective action. The following factors will be addressed for each alternative:

- $\quad$ Protection of the community from potential risks associated with implementation, such as fugitive dusts, transportation of hazardous materials, and explosion

- Protection of workers during implementation

- Environmental impacts that may result from implementation

- The amount of time until the corrective action objectives are achieved 


\section{Reduction of Toxicity, Mobility, and/or Volume}

Each CAA must be evaluated for its ability to reduce the toxicity, mobility, and/or volume of the contaminated media. Reduction in toxicity, mobility, and/or volume refers to changes in one or more characteristics of the contaminated media by the use of corrective measures that decrease the inherent threats associated with that media.

\section{Long-Term Reliability and Effectiveness}

Each CAA must be evaluated in terms of risk remaining at the CAU after the CAA has been implemented. The primary focus of this evaluation is on the extent and effectiveness of the control that may be required to manage the risk posed by treatment of residuals and/or untreated wastes.

\section{Feasibility}

The feasibility criterion addresses the technical and administrative feasibility of implementing a CAA and the availability of services and materials needed during implementation. Each CAA must be evaluated for the following criteria:

- Construction and Operation - Refers to the feasibility of implementing a CAA given the existing set of waste and site-specific conditions.

- Administrative Feasibility - Refers to the administrative activities needed to implement the CAA (e.g., permits, use restrictions, public acceptance, rights-of-way, off-site approval).

- Availability of Services and Materials - Refers to the availability of adequate off-site and on-site treatment, storage capacity, disposal services, necessary technical services and materials, and prospective technologies for each CAA.

\section{Cost}

Costs for each alternative are estimated for comparison purposes only. The cost estimate for each CAA includes both capital, and operation and maintenance costs, as applicable. The following is a brief description of each component:

- Capital Costs - Include direct costs that may consist of materials, labor, construction materials, equipment purchase and rental, excavation and backfilling, sampling and analysis, waste disposal, demobilization, and health and safety measures. Indirect costs are separate and not included in the estimates. 
- Operation and Maintenance - These are separate and include labor, training, sampling and analysis, maintenance materials, utilities, and health and safety measures; and are not included in the estimates. 


\section{C.4.0 Evaluation and Comparison of Alternatives}

The CAAs of clean closure and close in place were evaluated for the lead shielding wall based on the general corrective action standards described in Section C.3.1. This evaluation is presented in Table C.4-1. Both CAAs meet the general corrective action standards.

The CAAs were further evaluated based on the remedy selection decision factors described in Section C.3.2. This evaluation is presented in Table C.4-2. For each remedy selection decision factor the CAAs are ranked relative to each other. The CAA with the least desirable impact on the remedy selection decision factor will be given a ranking of one. The CAA with the most desirable impacts on the remedy selection decision factor will receive a ranking of two. If both CAAs have an equal impact on the remedy selection decision factor, both will receive an equal rank. The scoring listed in this table represents the sum of the remedy selection decision factor ranks for each CAA. 
Table C.4-1

Evaluation of General Corrective Action Standards

\begin{tabular}{|c|c|c|}
\hline \multicolumn{3}{|r|}{ Lead Wall } \\
\hline \multicolumn{3}{|r|}{ CAA 1, Clean closure } \\
\hline Standard & Comply? & Explanation \\
\hline $\begin{array}{l}\text { Protection of Human Health and } \\
\text { the Environment }\end{array}$ & Yes & $\begin{array}{l}\text { The lead material exceeding the risk-based action levels will be } \\
\text { removed. }\end{array}$ \\
\hline $\begin{array}{l}\text { Compliance with Media Cleanup } \\
\text { Standards }\end{array}$ & Yes & $\begin{array}{l}\text { The lead material exceeding the risk-based action levels will be } \\
\text { removed. }\end{array}$ \\
\hline $\begin{array}{l}\text { Control the Source(s) of the } \\
\text { Release }\end{array}$ & Yes & $\begin{array}{l}\text { The lead material exceeding the risk-based action levels will be } \\
\text { removed. }\end{array}$ \\
\hline $\begin{array}{l}\text { Comply with Applicable Federal, } \\
\text { State, and Local Standards for } \\
\text { Waste Management }\end{array}$ & Yes & $\begin{array}{l}\text { Removed lead waste can be managed in compliance with RCRA } \\
\text { standards. }\end{array}$ \\
\hline \multicolumn{3}{|c|}{ CAA 2, Close in place with administrative controls } \\
\hline Standard & Comply? & Explanation \\
\hline $\begin{array}{l}\text { Protection of Human Health and } \\
\text { the Environment }\end{array}$ & Yes & $\begin{array}{l}\text { All receptors will be protected from exposure to the lead as it is within a } \\
\text { concrete structure with reinforced concrete walls and floor and access } \\
\text { to the structure will be prevented by filling the structure with cement } \\
\text { grout. The lead is completely encased within a steel casing structure } \\
\text { and will be enveloped by cement grout. A Use Restriction will also be } \\
\text { implemented to prevent future site workers from inadvertent contact. }\end{array}$ \\
\hline $\begin{array}{l}\text { Compliance with Media Cleanup } \\
\qquad \text { Standards }\end{array}$ & Yes & $\begin{array}{l}\text { The lead has not been released into environmental media and a release } \\
\text { will be prevented by the containment afforded by the steel casing, the } \\
\text { cement grout, and the reinforced concrete structure. }\end{array}$ \\
\hline $\begin{array}{l}\text { Control the Source(s) of the } \\
\text { Release }\end{array}$ & Yes & $\begin{array}{l}\text { Release of the lead will be prevented by the containment afforded by } \\
\text { the steel casing, the cement grout, and the reinforced concrete } \\
\text { structure. }\end{array}$ \\
\hline $\begin{array}{l}\text { Comply with Applicable Federal, } \\
\text { State, and Local Standards for } \\
\text { Waste Management }\end{array}$ & Yes & $\begin{array}{l}\text { The lead wall will not be subject to hazardous waste management } \\
\text { regulations as it will not be removed or disturbed. }\end{array}$ \\
\hline
\end{tabular}


Table C.4-2

Evaluation of Remedy Selection Decision Factors

(Page 1 of 2)

\begin{tabular}{|c|c|c|}
\hline \multicolumn{3}{|r|}{ Lead Wall } \\
\hline \multicolumn{3}{|r|}{ CAA 1, Clean closure } \\
\hline Factor & Rank & Explanation \\
\hline $\begin{array}{l}\text { Short-Term Reliability and } \\
\quad \text { Effectiveness }\end{array}$ & 1 & $\begin{array}{l}\text { This alternative is reliable and effective but would expose remediation workers to } \\
\text { significant physical hazards associated with cutting apart a massive structure; } \\
\text { moving and managing heavy lead material. Workers will be exposed to } \\
\text { suspended oxidized lead particles and lead fumes resulting from cutting the steel } \\
\text { casings from around the lead core. Transportation of the lead will cause } \\
\text { increased risk to workers loading, unloading, and transporting the waste on } \\
\text { highways as well as increased risk to the public or workers using the highways or } \\
\text { living/working near those highways. The short-term increased physical hazards } \\
\text { and toxic exposures to remediation workers is significant. }\end{array}$ \\
\hline $\begin{array}{l}\text { Reduction of Toxicity, Mobility, } \\
\text { and/or Volume }\end{array}$ & 1 & $\begin{array}{l}\text { This alternative will result in an increase in toxicity to workers by increasing the } \\
\text { mobility of the lead from cutting the steel casings from around the lead core as } \\
\text { the abrasive cutting operation will suspend oxidized lead particles and heat from } \\
\text { the cutting will vaporize lead releasing toxic fumes. }\end{array}$ \\
\hline $\begin{array}{l}\text { Long-Term Reliability and } \\
\text { Effectiveness }\end{array}$ & 2 & $\begin{array}{l}\text { This alternative is reliable and effective in the long-term at protecting human } \\
\text { health and the environment because the lead material will be managed in a } \\
\text { landfill and future exposure to receptors will be prevented. }\end{array}$ \\
\hline Feasibility & 1 & $\begin{array}{l}\text { While feasible, the operation of disassembly of the lead wall, removal of the lead } \\
\text { material from within the structure, managing and packaging the waste, } \\
\text { transporting the waste, encapsulating the waste, and disposing of the waste is a } \\
\text { complicated and labor intensive operation. }\end{array}$ \\
\hline Cost & 1 & $\begin{array}{l}\text { The excavation and waste disposal costs for this alternative are estimated to be } \\
\$ 616,000 \text {. }\end{array}$ \\
\hline Score & 6 & \\
\hline \multicolumn{3}{|c|}{ CAA 2, Close in place with administrative controls } \\
\hline Factor & Rank & Explanation \\
\hline $\begin{array}{l}\text { Short-Term Reliability and } \\
\text { Effectiveness }\end{array}$ & 2 & $\begin{array}{l}\text { This alternative is reliable and effective in providing increased protection of } \\
\text { human health by preventing contact with the lead as it is within a concrete } \\
\text { structure with reinforced concrete walls and floor and access to the structure will } \\
\text { be prevented by filling the structure with cement grout. The lead is completely } \\
\text { encased within a steel casing structure and will be enveloped by cement grout. } \\
\text { A use restriction will also be implemented to prevent future site workers from } \\
\text { inadvertent contact. }\end{array}$ \\
\hline $\begin{array}{l}\text { Reduction of Toxicity, Mobility, } \\
\text { and/or Volume }\end{array}$ & 2 & $\begin{array}{l}\text { This alternative will reduce the toxicity and mobility of the lead as the lead will } \\
\text { remain encased in steel and will be enveloped by cement grout within a } \\
\text { reinforced concrete structure. This will provide a greater reduction of toxicity and } \\
\text { mobility than provided by macroencapsulation within a landfill as the effective } \\
\text { containment of the lead wall is much greater (encased in steel within a reinforced } \\
\text { concrete structure filled with cement grout). }\end{array}$ \\
\hline
\end{tabular}


Table C.4-2

Evaluation of Remedy Selection Decision Factors

(Page 2 of 2)

\begin{tabular}{||c|c|l||}
\hline \multicolumn{3}{||c||}{ LAA 2, Close in place with administrative controls } \\
\hline \hline $\begin{array}{c}\text { Lactor } \\
\text { Leng-Term Reliability and } \\
\text { Effectiveness }\end{array}$ & Rank & \multicolumn{1}{|c|}{ Explanation } \\
\hline $\begin{array}{c}\text { This alternative is reliable and effective in the long-term at protecting human } \\
\text { steel and will be enveloped by cement grout within a reinforced concrete } \\
\text { structure that is filled with cement grout and future exposure to receptors will be } \\
\text { prevented. }\end{array}$ \\
\hline Feasibility & 2 & There will be no incremental increase in effort for this alternative. \\
\hline Cost & 2 & There will be no incremental increase in costs for this alternative. \\
\hline Score & 10 & \\
\hline
\end{tabular}




\section{C.5.0 Recommended Alternatives}

The two CAAs were judged to meet all requirements for the general corrective action standards. The recommended CAAs presented in this section meet all applicable state and federal regulations for closure of the sites and will minimize potential future exposure pathways to the material in the lead wall.

Alternative 1, Clean Closure, is not the preferred corrective action for the lead wall. This alternative would subject workers and the public to significant increased risks during the corrective action, subsequent management and transportation of the wastes to a disposal facility, and treatment and management of the wastes at the disposal facility. The final disposal of the lead wall waste material at the landfill will require the cut apart pieces of the lead wall to be macroencapsulated with surface coating materials such as polymeric organics (e.g., resins and plastics) or with a jacket of inert inorganic materials (e.g.steel drums) before being placed in a landfill. While this containment affords adequate protection to the public or environment, it does not afford as much containment as Alternative 2 (i.e., entombing the lead wall in place within a steel casing within a reinforced concrete structure that has been filled with cement grout).

Alternative 2, Close in Place with administrative controls, was the highest-scoring CAA in Table C.4-2 and is selected as the preferred corrective action for the lead wall. Selection of this CAA is consistent with past practices for sites that contain contaminants where the removal of contaminated media is not feasible, the removal does not afford a significant reduction of risk, the removal alternative cannot be safely completed, and/or where there is limited future exposure to receptors to the contamination. With regard to the lead wall, the activities recommended to meet the requirements of Alternative 2, Close in Place with administrative controls, include:

- Backfilling void space around lead wall and throughout the underground structure with flowable cement grout.

- Addition of this area to the FFACO use restriction database, and placement of signs at the site to warn of the presence of underground contamination. 


\section{C.6.0 References}

CFR, see Code of Federal Regulations.

Code of Federal Regulations. 2003a. Title 40 CFR Parts 260 - 282, "Hazardous Waste Management.” Washington, D.C.: U.S. Government Printing Office.

Code of Federal Regulations. 2003b. Title 40 CFR 761, "Polychlorinated Biphenyls (PCBs) Manufacturing, Processing, Distribution in Commerce and Prohibitions.” Washington, D.C.: U.S. Government Printing Office.

EPA, see U.S. Environmental Protection Agency.

NAC, see Nevada Administrative Code.

Nevada Administrative Code. 2002. NAC 444.842 to 444.9809, “Management of Hazardous Waste.” Carson City, NV.

U.S. Environmental Protection Agency. 1991. Guidance on RCRA Corrective Action Decision Documents, EPA/540/G-91/011. Washington, D.C.: Office of Research and Development.

U.S. Environmental Protection Agency. 1994. Final RCRA Corrective Action Plan, EPA/520-R-94-004. Washington, D.C.: Office of Solid Waste and Emergency Response. 
Appendix D

Risk Evaluation of Lead Wall Closure Alternatives 


\section{D.1.0 Introduction}

This section provides a quantitative evaluation of the chemical, physical, and radiological risks associated with the two closure alternatives of the lead wall in Building 5400, CAU 118. A comparison and discussion of associated regulatory citations is also presented. This evaluation and comparison is supplemental to the qualitative analysis presented in Appendix C, Alternative Evaluation for the Lead Shielding Wall. This appendix focuses on worker exposure to the aforementioned risks associated with leaving the lead wall in place versus its removal and disposal at a permitted facility.

In formulating the comparative risks, it is necessary to state the assumptions associated with the removal of the lead wall as follows:

If the lead shielding wall were to remain in Building 5400:

- All void space around the lead wall and throughout the Building 5400 structure will be filled with flowable cement grout.

- CAU 118 will be added to the FFACO use restriction database, and signs will be placed at the site to warn of the presence of underground contamination.

If the lead shielding wall were removed from Building 5400:

- The wall would be appropriate for disposal at an approved MLLW facility due to its classification as having DOE Rad-added contamination/activation.

- The lead bricks inside the steel casing would be oxidized, increasing risk to workers dismantling the wall, transporting the lead to a treatment and disposal facility, and treating the lead for disposal.

- Workers would be required to use handheld power tools to remove equipment, conduit, piping, and other items attached to or blocking the removal of the lead wall.

- Workers would be required to remove paint containing lead and PCBs covering the welded seams between the two sections of the wall.

- Workers would be required to use a torch to separate sections of the lead wall. 
- Heavy equipment would be used to remove the sections of the lead wall from Building 5400 and to package and load them for transport.

- Once packaged and loaded, the lead wall sections would be transported to an appropriate offsite disposal facility.

- $\quad$ Lead wall sections would be treated by macroencapsulation and placed in a landfill.

The following additional worker activities would also be associated with the work steps listed above:

- Verifying the absence of power/utilities to Building 5400

- Performing Hantavirus cleanup

- Collection of paint samples for additional health and safety concerns

- Draining/sampling mineral oil from the viewing window

- Performing initial and in-process radiation surveys

- Performing initial and in-process industrial health surveys

- Additional training necessary for employees working with lead

- Based on an estimate from the M\&O organization, approximately 1,608 construction worker hours will be needed to complete all activities associated with the removal of the lead shielding wall including site setup, execution, and closeout. Additional hours will be required to provide health and safety monitoring and oversight (see Table D.D.2-1). 


\section{D.2.0 Industrial Health and Physical Hazards}

The CAU 118 Super Kukla Site, Building 5400 (the reactor building and basement with the high bay 5400A above) consists of a reactor and associated components. Within the reactor building situated approximately $5 \mathrm{ft}$ away from the reactor core is a lead wall encapsulated in stainless steel that is painted with a gadolinium-based paint (herein referred to as the lead wall). There is a question regarding whether the lead wall should be left in place or removed, and if removed, what safety and health-related risks are involved?

\section{D.2.1 Health and Safety-Related Hazards Associated with Leaving in Place}

Because the Building 5400 lead wall is encapsulated in stainless steel, it poses zero risk from an occupational injury and illness perspective. The gadolinium-based paint that covers the outer wall is intact and presents no occupational health hazard in its present condition. In addition, because Building 5400 will be filled with flowable grout, future access to the facility will be discontinued, thereby virtually assuring no future potential exposure to lead or gadolinium-based paint health hazards.

\section{D.2.2 Health and Safety-Related Hazards Associated with Removal}

\section{D.2.2.1 Safety-Related Hazards}

The safety-related health hazards associated with removing the lead wall include physical injury potential from the tasks associated with wall removal, and the potential health hazards associated with lead and gadolinium-based paint removal. A summary of tasks associated with wall removal including estimated exposure hours for each task is provided in Table D.D.2-1.

For statistical comparison purposes, the exposure has been estimated to be 2000 hours. Hours of exposure do not include hours associated with administrative functions (e.g., work planning and control document preparation). These administrative functions pose negligible risk and are excluded from this assessment.

The tasks involved with the wall removal encompass a variety of construction-related activities. Included are paint scraping/removal, cutting/burning, material handling, portable and mobile 
Table D.2-1

Tasks and Estimated Hours Associated with Wall Removal

\begin{tabular}{|c|c|}
\hline Wall Removal Tasks & Estimated Exposure Hours \\
\hline Collect paint samples form shield wall & 40 \\
\hline Drain and sample mineral oil & 40 \\
\hline Initial rad surveys & 35 \\
\hline Verify absence of power & 18 \\
\hline Hantavirus cleanup & 32 \\
\hline Lead wall clearance & 280 \\
\hline Prepare lead wall & 155 \\
\hline Remove lead wall & 774 \\
\hline Demobilize equipment and labor & 34 \\
\hline Mixed waste transport and disposal & 160 \\
\hline Drive to Envirocare & 40 \\
\hline $\begin{array}{c}\text { Oversight activities } \\
\text { (Site Safety Supervisor, Radiological Control Technician, }^{\text {Sulte Safety Officer: } 3 \times 182 \text { hours) }}{ }^{a}\end{array}$ & 546 \\
\hline Total & 2,154 \\
\hline
\end{tabular}

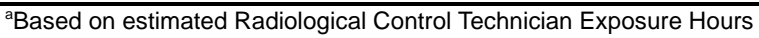

equipment use, and transportation. Lead and steel removal alone will require movement of approximately 79,000 lbs of material, representing a significant material handling risk.

In its latest injury statistics (2004), the U.S. Bureau of Labor Statistics published a nation-wide construction industry Occupational Safety and Health Administration (OSHA) total recordable case rate of 6.4 injuries per 200,000 exposure hours, and a lost workday rate (Days Away, Transfer and Restricted Work) of 3.4 injuries per 200,000 exposure hours (BLS, 2004a). Nevada published a rate of 8.8 construction injuries per 200,000 hours, and a lost workday rate of 5.2 injuries per 200,000 exposure hours for the same period (BLS, 2004b).

Considering 2,000 exposure hours for wall removal tasks and applying the national average construction injury rates, the probability (likelihood) of physical injury resulting from the activity can be estimated based on the national and state rates of injury. The number of physical injuries meeting OSHA criteria for recordability is estimated between 0.064 and 0.088 for the task, and the number of lost workday injuries is estimated between 0.034 and 0.052 . 
Similarly, nationwide truck transportation statistics for 2004 listed a rate of 6.1 total injuries per 200,000 exposure hours and a lost workday case rate of 3.9 (BLS, 2004a). Nevada transit rates were higher, listing a total recordable case rate of 10.9 injuries and a lost workday rate of 7.1 injuries per 200,000 exposure hours (BLS, 2004b). Considering 200 estimated transport exposure hours, the number of physical injuries matching OSHA recordability thresholds for this task is estimated between 0.0061 and 0.019 , with the number of lost workday injuries between 0.0039 and 0.0071 .

\section{D.2.2.2 Health-Related Hazards}

Removal of the gadolinium-based paint containing lead and PCBs that covers the outer wall will be required for wall disassembly. This will involve physical scraping and the potential for creating dust. Cutting and burning will create fumes. Once the stainless steel outer wall is removed, manual handling of approximately 73,500 lbs of lead bricks will be required. The OSHA lead standard requirements (29 CFR 1910.1025 and 1926.62) (CFR 2005a) will apply. Airborne sampling will be required for lead dust exposure. Personal protective equipment will be required during the performance of these tasks to include respiratory protection. Worker medical monitoring will be required, including monitoring of blood lead levels. Coordination with the NNSA/NSO Occupational Medicine Group and adherence to applicable procedures will be required.

\section{D.2.3 Summary}

Although medical monitoring, PPE, and administrative controls in the form of work control procedures are designed to minimize exposure risk, the potential for exposure and adverse consequence is greater than zero.

Based on nationwide and state injury rates, the potential for OSHA recordable occupational injuries, including lost workday injuries resulting from this work, can be estimated to be less than one but greater than zero. Adequate work controls in the form of administrative procedures, exposure monitoring and medical surveillance, and appropriate PPE will contribute to hazard mitigation but not reduce risk to zero as would be the case if the wall remained in place. 


\section{D.3.0 Radiological Hazards}

This section presents a quantitative comparison of the radiological hazards and/or risks associated with leaving in place and removing the lead wall in Building 5400.

\section{D.3.1 Radiological Hazards Associated with Leaving in Place}

The only radiological hazard associated with leaving the lead wall in place is the radiation fields to which personnel accessing the area could be exposed. The dose rate surveys conducted for the Super Kukla Site are summarized in Table D.D.3-1.

Table D.3-1

Summary of External Dose Rates for CAU 118

\begin{tabular}{||l|c|c|c||}
\hline \multicolumn{1}{|c|}{$\begin{array}{c}\text { Characterization } \\
\text { Unit }\end{array}$} & Survey Dates & $\begin{array}{c}\text { Dose Rate } \\
(\mu \mathrm{rem} / \mathrm{hr})\end{array}$ & Description \\
\hline \hline C (5400A interior) & $\begin{array}{c}\text { February } 8,2006 \\
\text { February 13, 2006 }\end{array}$ & 10 & $\begin{array}{c}\text { Maximum dose rate } \\
\text { throughout }\end{array}$ \\
\hline D (5400A exterior) & February 8, 2006 & 10 & $\begin{array}{c}\text { Maximum dose rate } \\
\text { throughout }\end{array}$ \\
\hline E (5400 hallway) & February 8, 2006 & 45 & $\begin{array}{c}\text { Maximum dose rate } \\
\text { throughout }\end{array}$ \\
\hline F (5400 west reactor room) & February 9, 2006 & 300 & $\begin{array}{c}\text { Maximum dose rate } \\
\text { throughout }\end{array}$ \\
\hline G (5400 east reactor room) & February 9, 2006 & 85 & Maximum dose rate within \\
reactor diameter \\
\hline G (5400 east reactor room)
\end{tabular}

mrem $=$ Millirem

$\mu \mathrm{mrem} / \mathrm{hr}=$ Micromillirem per hour

Note that none of these areas are radiation areas, and with the exception of Characterization Unit G, all the areas contain radiation fields within the limit of a controlled area. In addition, because access to the facility will be discontinued (i.e., filled with flowable grout), it is expected that there will be no further personnel exposure to these radiation fields upon completion of closure activities. 


\section{D.3.2 Radiological Hazards Associated with Removal}

The radiological hazards associated with removing the lead wall include:

- Radiation fields to which personnel accessing the area could be exposed.

- Possible ingestion and/or inhalation of radioactive material due to intrusive activities during removal.

\section{D.3.2.1 External Doses}

The dose rate surveys summarized in Table D.D.3-1 and the estimated number of work hours to remove the lead wall (1,608 hours for construction workers) (M\&O, 2006) can be used to estimate the maximum individual dose and the maximum collective dose for the work activities performed by construction worker personnel (excludes oversight personnel, as listed in Table D.D.2-1). It is likely that personnel would not access the reactor diameter (area of highest dose exposure rates) except for a Radiological Control Technician (RCT) during a survey. To be conservative, assume that personnel performing the work access the reactor diameter approximately 5 percent of the work hours, the east side of the lead wall approximately 75 percent of the work hours, and the west side of the lead wall approximately 20 percent of the work hours. Also note that of the type of work required, an RCT has the potential to spend the maximum amount of work time on this project, with a potential total of 182 hours (M\&O, 2006). The maximum individual and the collective doses would be approximately 16 millirem (mrem) and 141 mrem, as shown in Table D.D.3-2.

Table D.3-2

Summary of External Dose Estimates for CAU 118

\begin{tabular}{||c|c|c|c|c|c||}
\hline Location & $\begin{array}{c}\text { Dose Rate } \\
(\mu \mathrm{rem} / \mathrm{hr})\end{array}$ & $\begin{array}{c}\text { Collective } \\
\text { Hours }\end{array}$ & $\begin{array}{c}\text { Maximum } \\
\text { Individual } \\
\text { Hours }\end{array}$ & $\begin{array}{c}\text { Collective } \\
\text { Dose } \\
\text { (mrem) }\end{array}$ & $\begin{array}{c}\text { Maximum } \\
\text { Individual } \\
\text { Dose } \\
\text { (mrem) }\end{array}$ \\
\hline \hline Reactor diameter & 300 & 80.4 & 9.1 & 24.12 & 2.73 \\
\hline $\begin{array}{c}\text { East side of } \\
\text { lead wall }\end{array}$ & 85 & $1,206.0$ & 136.5 & 102.51 & 11.60 \\
\hline $\begin{array}{c}\text { West side of } \\
\text { lead wall }\end{array}$ & 45 & 321.6 & 36.4 & 14.47 & 1.67 \\
\hline \hline & & & Total & $\mathbf{1 4 1 . 1 0}$ & $\mathbf{1 5 . 9 7}$ \\
\hline
\end{tabular}


These dose estimates are less than the requirements for a formal ALARA review as indicated in Chapter 3, Section 312, Step 3 of the NV/YMP Radiological Control Manual (NNSA/NSO, 2004); however, they are above the negligible dose associated with leaving the wall in place, which is essentially zero due to the minimal worker hours required. The16 mrem potential maximum individual dose is approximately 16 percent of the total effective dose equivalent limit for members of the public entering a controlled area (CFR, 2003).

\section{D.3.2.2 Internal Doses}

In addition to receiving external doses, personnel working on the removal of the lead may have the potential to ingest and/or inhale radioactive material due to intrusive activities. To determine if there is any residual radioactive material due to activation of the lead wall, it is necessary to determine the materials present as follows:

- The wall is composed of 73,479 lbs of natural lead, 5,300 lbs of stainless steel, and the mass of the paint is irrelevant compared to the mass of the lead and steel (Sanford, 2006).

- Natural lead is composed of 1.4 percent lead $(\mathrm{Pb})-204,24.1$ percent $\mathrm{Pb}-206,22.1$ percent $\mathrm{Pb}-207$, and 52.4 percent $\mathrm{Pb}-208$ (WebElements, 2006).

- The basic composition of Type 304 stainless steel is 71 percent iron, 19 percent chromium, and 10 percent nickel (WISE, 2006).

- Natural iron is composed of 5.8 percent Fe-54, 91.8 percent Fe-56, 2.1 percent Fe-57, and 0.3 percent Fe-58 (WebElements, 2006).

- Natural chromium is composed of 4.3 percent chromium (Cr)-50, 83.8 percent Cr-52, 9.5 percent Cr-53, and 2.4 percent Cr-54 (WebElements, 2006).

- Natural nickel is composed of 68.1 percent Ni-58, 26.2 percent Ni-60, 1.2 percent Ni-61, 3.6 percent Ni-62, and 0.9 percent Ni-64 (WebElements, 2006).

From the materials present, it is possible to identify the activation products of significance (with reasonably large atomic cross sections and long half-lives) as shown in Table D.D.3-3.

The data in Table D.D.3-3 have been taken from Handbook of Health Physics and Radiological Health, (Table 7.18.1, Shleien et al., 1998), with the exception of the Isotopic Abundances, as referenced previously. 
Table D.3-3

Activation Products for Natural Lead and Stainless Steel

\begin{tabular}{|c|c|c|c|c|c|c|}
\hline Target & $\begin{array}{c}\text { Isotopic } \\
\text { Abundance } \\
\mathbf{( \% )}\end{array}$ & Reaction & $\begin{array}{c}\text { Reaction } \\
\text { Type }\end{array}$ & $\begin{array}{c}\text { Cross } \\
\text { Section } \\
\text { (barns) }\end{array}$ & Product & Half-Life \\
\hline \hline Iron-54 & 5.8 & Activation & Thermal & 2.25 & Iron-55 & $2.70 \mathrm{y}$ \\
\hline Nickel-58 & 68.1 & Activation & Thermal & 4.6 & Nickel-59 & $7.5 \times 10^{4} \mathrm{y}$ \\
\hline Nickel-58 & 68.1 & $\mathrm{n}, \mathrm{a}$ & Fast & 0.003 & Iron-55 & $2.70 \mathrm{y}$ \\
\hline Nickel-60 & 26.2 & $\mathrm{n}, \mathrm{p}$ & Fast & 0.002 & Cobalt-60 & $5.27 \mathrm{y}$ \\
\hline Nickel-60 & 26.2 & $\mathrm{n}, \mathrm{p}$ & Fast & 0.002 & Cobalt-60m & $10.48 \mathrm{~m}$ \\
\hline $\begin{array}{l}\text { Nickel-62 } \\
\text { L Lead-204 }\end{array}$ & 3.6 & Activation & Thermal & 14.5 & Nickel-63 & $100.00 \mathrm{y}$ \\
\hline $\begin{array}{l}\mathrm{a}=\text { Alpha } \\
\mathrm{m}=\text { Month } \\
\mathrm{n}=\text { Neutron } \\
\mathrm{p}=\text { Proton } \\
\mathrm{y}=\text { Year }\end{array}$ & Activation & Thermal & 0.661 & Lead-205 & $14 \times 10^{6} \mathrm{y}$ \\
\hline
\end{tabular}

It is apparent that there may be some long-lived activation products present in the lead wall. The same hazard migration controls put in place to protect workers removing the wall from exposure to lead (e.g., respiratory protection, Tyvek ${ }^{\circledR}$ ) would be the same controls put in place to protect workers from ingesting/inhaling radioactive particles.

\section{D.3.3 Summary}

The radiological hazards for either action are expected to be minimal. However, as shown in Table D.D.3-2, removal of the wall could result in an estimated maximum worker dose of 16 milli-roentgen equivalent man as compared to zero for leaving the wall in place. If the wall is removed, the potential to encounter unknown radiological exposure or contaminants exists, but is unlikely. Should removal of the lead wall be the preferred corrective action, appropriate actions to ensure worker doses are kept ALARA will be taken. 


\section{D.4.0 RCRA Regulatory Analysis}

The following provides a regulatory evaluation concerning the proposed closure in place of the shielding wall in the Super Kukla Reactor Containment Building. The regulatory evaluation of the closure in place alternative considered two primary factors, below, and regulatory citings are italicized throughout this section:

- Hazardous constituents (i.e., lead)

- Environmental setting of the closed facility

\section{D.4.1 Hazardous Constituents}

The primary hazardous constituent is lead that is contained in the shielding wall. The shielding wall is approximately $10 \mathrm{ft}$ high, $15 \mathrm{ft}$ long, and 8.5-in. thick, and is constructed of $8 \mathrm{in}$. of lead encased between two $1 / 4$-in. steel plates. The shielding wall is located in the underground level of the reactor containment building and is attached to a 3-ft thick concrete floor. Implementation of the closure in place alternative would include filling the containment building with grout.

Upon closure, the lead would be encased in $1 / 4$-in. steel, a minimum of $3 \mathrm{ft}$ of reinforced concrete below the wall, and grout encasing the sides extending approximately $10 \mathrm{ft}$ above the wall to the 2-ft thick reinforced concrete ceiling.

As a comparison, the treatment standard for radioactive lead solid is MACRO and is defined by 40 CFR 268.42 (CFR, 2005c) as:

Macroencapsulation with surface coating materials such as polymeric organics (e.g., resins and plastics) or with a jacket of inert inorganic materials to substantially reduce surface exposure to potential leaching media. Macroencapsulation specifically does not include any material that would be classified as a tank or container according to 40 CFR 260.10.

The lead being encased in $1 / 4$-in. steel with the addition of several feet of grout (both inert inorganic materials) and reinforced concrete will substantially reduce the surface exposure to potential leaching media, thus providing a barrier to the surrounding subsurface soils and environment. 


\section{D.4.2 Environmental Setting}

Two regulations provide guidance concerning site suitability when assessing closure in place. Specifically, the NAC concerning the factors to be considered in determining whether to perform remedial actions (NAC 445A.227) (NAC, 2006), and 40 CFR 264.601 and 264.603 (Environmental Performance Standards) (CFR, 2005b). The following provides an evaluation of these requirements to the facility after closure in place has been completed.

\section{D.4.2.1 NAC 445A.227}

NAC 445A.227, Contamination of soil: Order by Director for corrective action; factors to be considered in determining whether corrective action required. (NRS 445A.425)

1. Except as otherwise provided in NAC 445A.22715, the Director may require an owner or operator to take corrective action if the release of a hazardous substance, hazardous waste or a regulated substance contaminates soil and the level of contamination exceeds the action level established for the soil pursuant to NAC 445A.2272.

2. In determining whether corrective action is required, the Director shall consider:

(a) The depth of any groundwater;

The Super Kukla Site is located approximately $1.7 \mathrm{mi}$ southeast of Test Well F (USGS/USDOE, 2006) and has a groundwater level of approximately 1,735 ft below the surface at an elevation of approximately 2,408 ft above sea level (USGS/USDOE, 2006). The well has a surface elevation of approximately 4,142.7 ft above sea level (USGS/USDOE, 2006). Groundwater appears to be from the carbonate aquifer and has a temperature of $48{ }^{\circ}$ Celsius (USGS/USDOE, 2006). The water from this well is not currently being used, although in the past it was used as construction water.

(b) The distance to irrigation wells or wells for drinking water;

The closest water well that supplies potable water is water well 5-B located in Area 5, approximately $8.8 \mathrm{mi}$ east-northeast of the Super Kukla Site (USGS/USDOE, 2006). The groundwater at this location has a water level of approximately $687 \mathrm{ft}$ below the surface at an elevation of approximately 2,405 ft above sea level (USGS/USDOE, 2006). The well has a surface elevation of approximately 
3,092.13 ft above sea level (USGS/USDOE, 2006). Groundwater appears to be from the consolidated deposits and has a temperature of $23{ }^{\circ}$ Celsius (USGS/USDOE, 2006). This well is listed as being an active water supply well.

(c) The type of soil that is contaminated;

No hazardous constituents have been released, therefore, no soil has been contaminated. The site characteristics are described in Section 3.1.1.2.4.

(d) The annual precipitation;

Annual precipitation is approximately 7.8 in. per year based on NNSA/NSO data on Cane Springs rainfall measurements (1964 to 2005) (ARL, 2005); and 3 to 4 in. per year per LRL Report 1964 (LRL, 1964).

(e) The type of waste or substance that was released;

No waste nor hazardous substance has been released. See the discussion in Section D.4.1 for information regarding hazardous constituents and encapsulation.

(f) The extent of the contamination;

There have been no releases of hazardous (i.e., lead) materials, therefore, there is no hazardous contamination present.

(g) The present and potential use for the land;

The Super Kukla Facility is currently an inactive facility on the NTS and within in a secure area of the NTS. The facility is undergoing D\&D following the FFACO SAFER process. The site will be "Use Restricted” for future use.

(h) The preferred routes of migration;

Migration pathways and transport mechanisms are discussed in Section 3.1.1.2.5. In addition to the mechanisms discussed that would prevent the migration of hazardous constituents, credit should also 
be taken for the steel plate, 14-in. thick reinforced concrete walls, 36-in. thick floor, and the approximately 800 to 1000 cubic yards of flowable grout that will be encapsulating the hazardous constituents.

(i) The location of structures or impediments;

Buildings are discussed in detail in Section 1.0. None of these building or structures should have any impact to the integrity of the shield wall or the grout filled containment room.

(j) The potential for a hazard related to fire, vapor or an explosion;

None of these hazards are credible since the shield wall and containment room will be underground and filled with grout.

(k) Any other information specifically related to the site which the director determines is appropriate.

\section{D.4.2.2 40 CFR 264.603 and 264.601}

40 CFR 264.603 requires that: "A miscellaneous unit that is a disposal unit must be maintained in a manner that complies with 264.601 during the post-closure care period” (CFR, 2005b). Although upon completion of the closure in place alternative this unit is not defined as a closed disposal unit, the environmental performance standards in 264.601 provide applicable guidance concerning the protection of human health and the environment as it applies to the closure in place alternative.

40 CFR 264.601 states in part that: “A miscellaneous unit must... closed in a manner that will ensure protection of human health and the environment... Protection of human health and the environment includes, but is not limited to" (CFR, 2005b):

(a) Prevention of any releases that may have adverse effects on human health or the environment due to migration of waste constituents in the ground water or subsurface environment, considering:

1) The volume and physical and chemical characteristics of the waste in the unit, including its potential for migration through soil, liners, or other containing structures; 
Discussion concerning the hazardous constituents is provided in Section D.4.1.

2) The hydrologic and geologic characteristics of the unit and the surrounding area;

The site characteristics are described in Section 3.1.1.2.4.

3) The existing quality of ground water, including other sources of contamination and their cumulative impact on the ground water;

Addressed in Section D.4.2.1 under the NAC comparison.

4) The quantity and direction of ground-water flow;

Addressed in Section D.4.2.1 under the NAC comparison.

5) The proximity to and withdrawal rates of current and potential ground-water users;

Addressed in Section D.4.2.1 under the NAC comparison.

6) The patterns of land use in the region;

Addressed in Section D.4.2.1 under the NAC comparison.

7) The potential for deposition or migration of waste constituents into subsurface physical structures, and into the root zone of food-chain crops and other vegetation;

8) The potential for health risks caused by human exposure to waste constituents; and

9) The potential for damage to domestic animals, wildlife, crops, vegetation, and physical structures caused by exposure to waste constituents;

Concerning items 7, 8, and 9, migration pathways and transport mechanisms are discussed in Section 3.1.1.2.5. In addition to the mechanisms discussed that would prevent the migration of hazardous constituents, credit should also be taken for the steel plate, 14-in. thick walls, 36-in. thick reinforced concrete floor, and grout encapsulating the hazardous constituents. 


\section{D.4.3 Summary}

The above analysis demonstrates that no potential for contaminants from Building 5400 exist to infiltrate 1,735 ft of earth to groundwater. As discussed previously, the robustness of the existing concrete structures (i.e., floors, walls and ceiling), and the pending grouting of void space, provide an excellent barrier to the surrounding environment and meets the intent of macroencapsulation as noted in 40 CFR 268.42. 


\section{D.5.0 References}

ARL, see Air Resources Laboratory

Air Resources Laboratory. 2005. Nevada Test Site (NTS) Climatological Rain Gauge Data. As accessed at http://www.sord.nv.doe.gov on 21 August 2006.

BLS, see U.S. Department of Labor, Bureau of Labor Statistics.

CFR, see Code of Federal Regulations

Code of Federal Regulations. 2003. Title 10 CFR, Part 835, “Occupational Radiation Protection.” Washington, D.C.: U.S. Government Printing Office.

Code of Federal Regulations. 2005a. Title 29 CFR, Part 1910, "Occupational Safety and Health Standards.” Washington, D.C.: U.S. Government Printing Office.

Code of Federal Regulations. 2005b. Title 40 CFR, Part 264, "Standards for Owners and Operators of Hazardous Waste Treatment, Storage, and Disposal Facilities.” Washington D.C.:

U.S. Government Printing Office.

Code of Federal Regulations. 2005c. Title 40 CFR, Part 268, "Land Disposal Restrictions.” Washington D.C.: U.S. Government Printing Office.

LRL, see Lawrence Livermore National Laboratory, Lawrence Radiation Laboratory.

Lawrence Livermore National Laboratory, Lawrence Radiation Laboratory. 1964. Revised Safety Analysis Report for the Super Kukla Prompt Burst Reactor, Rev. 1. UCRL-7695. Prepared by W.S. Gilbert, F.A. Kloverstrom, and F. Rienecker Jr., Livermore, CA.

$\mathrm{M} \& \mathrm{O}$, see management and operating contractor.

Management and operating contractor. 2006. Preliminary estimate of worker hours necessary to complete removal of lead wall. Submitted to David Strand week of 14 August.

NAC, see Nevada Administrative Code.

Nevada Administrative Code. 2006. NAC 445A.227, “Contamination of Soil: Order by Director for Corrective Action; Factors to be Considered in Determining Whether Corrective Action Required.” Carson City, NV.

NNSA/NSO, see U.S. Department of Energy, National Nuclear Security Administration Nevada Site Office. 
Sanford, Peter. SAIC. 2006. Super Kukla Reactor Decommissioning Engineering Analysis and Estimate, 25 May. Las Vegas, NV.

Shleien B., et. al., ed. 1998. Handbook of Health Physics and Radiological Health. Baltimore, MD.

U.S. Department of Energy, National Nuclear Security Administration Nevada Site Office. 2004. NV/YMP Radiological Control Manual, Rev. 5, DOE/NV/11718-079, UC-702. Prepared by A.L. Gile of Bechtel Nevada. Las Vegas, NV.

U.S. Department of Labor, Bureau of Labor Statistics. 2004a. Table 1. Incidence rates of nonfatal occupational injuries and illnesses by industry and case types, 2004. As accessed at http://www.bls.gov/iif/oshwc/osh/os/ostb1487.pdf on 20 August 2006.

U.S. Department of Labor, Bureau of Labor Statistics. 2004b. Table 6. Incidence Rates of nonfatal occupational injuries and illnesses by industry and case types, 2004, Nevada. As accessed at http://www.bls.gov/iif/oshwc/osh/os/pr046nv.pdf on 20 August 2006.

USGS/USDOE, see U.S. Geological Survey and U.S. Department of Energy.

U.S. Geological Survey and U.S. Department of Energy. 2006. Cooperative Studies in Nevada. As accessed at http://nevada.usgs.gov/doe\%5Fnv on 21 August.

WebElements. 2006. Periodic Table, Professional Edition, Links to naturally occurring isotopes data. As accessed at http://www.webelements.com/webelements/elements/text/periodic-table/ isot.html on 19 August. Prepared by Mark Winter. The University of Sheffield, UK.

WISE, see WISE Uranium Project.

WISE Uranium Project. 2004. Neutron Activation Calculator. As accessed at http://www.wise-uranium.org/rnac.html on 19 August 2006. 


\section{Appendix E}

\section{Nevada Division of Environmental Protection Comments}




\section{NEVADA ENVIRONMENTAL RESTORATION PROJECT} DOCUMENT REVIEW SHEET

\begin{tabular}{|c|c|c|}
\hline 1. Document Title/Number: & $\begin{array}{l}\text { Final Final Streamlined Approach for Environmental Restoration } \\
\text { (SAFER) Plan for Corrective Action Unit 118: Area } 27 \text { Super Kukla } \\
\text { Facility, Nevada Test Site, Nevada }\end{array}$ & 2. Document Date: 09/19/2006 \\
\hline \multicolumn{2}{|l|}{ 3. Revision Number: 0} & 4. Originator/Organization: Stoller-Navarro \\
\hline \multicolumn{2}{|c|}{ 5. Responsible NNSA/NV ERP Project Manager: Kevin Cabble } & 6. Date Comments Due: 09/19/2006 \\
\hline \multicolumn{2}{|l|}{ 7. Review Criteria: Full } & \\
\hline \multicolumn{2}{|c|}{ 8. Reviewer/Organization/Phone No: Jeff MacDougall and Don Elle, NDEP, 486-2850 } & 9. Reviewer's Signature: \\
\hline
\end{tabular}

\begin{tabular}{|c|c|c|c|c|}
\hline $\begin{array}{l}\text { 10. Comment } \\
\text { Number/Location }\end{array}$ & 11. Type* & 12. Comment & 13. Comment Response & $\begin{array}{c}14 . \\
\text { Accept }\end{array}$ \\
\hline $\begin{array}{l}\text { 1.) Page } 67 \text { of } 68 \text {, } \\
\text { Sections } 4.2 .4 .2 .1 \\
\text { and } 4.2 .4 .3\end{array}$ & Mandatory & $\begin{array}{l}\text { Change the spelling of the word "outway" to "outweigh". In } \\
\text { addition, with the subsequent inclusion of Appendices C } \\
\text { and D resulting from review of the draft document, any } \\
\text { discussion of cost benefits is no longer pertinent since the } \\
\text { remediation choice is ultimately justified by a risk analysis. } \\
\text { Any mention of cost only serves to confuse the issue in the } \\
\text { public eye and takes away from the technical merits of the } \\
\text { risk analysis. These sections should be rewritten to reflect } \\
\text { observation. }\end{array}$ & $\begin{array}{l}\text { The spelling errors on page } 67 \text { (Sections 4.2.4.2.1 } \\
\text { and 4.2.4.3) have been corrected as noted. } \\
\text { The only discussion of cost benefits in Appendix C } \\
\text { is located on Page C-13 of C-14, third paragraph, } \\
\text { second sentence - "the benefits of removal are not } \\
\text { commensurate with the costs". This text has been } \\
\text { replaced with "the removal does not afford a } \\
\text { significant reduction of risk" in order to focus on } \\
\text { the risk benefit instead of the cost benefit. } \\
\text { The only other occurrences of cost in Appendix C } \\
\text { are necessary to address the Remedy Selection } \\
\text { Decision Factor of cost as required for the } \\
\text { evaluation of Corrective Action Alternatives in the } \\
\text { approved FFACO CADD outline. } \\
\text { The Appendix D, Risk Evaluation of Lead Wall } \\
\text { Alternatives does not address cost benefits. }\end{array}$ & \\
\hline $\begin{array}{l}\text { 3.) Page D-9 of D- } \\
\text { 17, Section D.3.3, } \\
\text { 2nd Line }\end{array}$ & Mandatory & $\begin{array}{l}16 \text { roentgen equivalent man should instead be } 16 \text { milli- } \\
\text { roentgen equivalent man. }\end{array}$ & $\begin{array}{l}\text { The spelling error on page D- } 9 \text { has been corrected } \\
\text { as noted. }\end{array}$ & \\
\hline
\end{tabular}




\section{Library Distribution List}

\section{$\underline{\text { Copies }}$}

U.S. Department of Energy

1 (Uncontrolled)

National Nuclear Security Administration

Nevada Site Office

Technical Library

P.O. Box 98518, M/S 505

Las Vegas, NV 89193-8518

U.S. Department of Energy

Office of Scientific and Technical Information

1 (Uncontrolled, electronic copy)

P.O. Box 62

Oak Ridge, TN 37831-0062

Southern Nevada Public Reading Facility

2 (Uncontrolled, electronic copy)

c/o Nuclear Testing Archive

P.O. Box 98521, M/S 400

Las Vegas, NV 89193-8521

Manager, Northern Nevada FFACO

1 (Uncontrolled, electronic copy)

Public Reading Facility

c/o Nevada State Library \& Archives

Carson City, NV 89701-4285 